\title{
1. Demystification of mergers and historical overview
}

The discussions in this chapter will be divided into two main topics. The first topic will be a historical overview, and the second topic will be demystification of mergers. Under the topic of historical overview, four main subtopics will be addressed. The first will be the origins of the idea of corporation, and that will mainly show how the origin of the idea of corporation and its early developments were attributed to ethnic and religious groups - mainly the Greeks, Romans, Muslims, Italians - and some even claimed that Jews had contributed to the development of the corporation in one way or another. The second subtopic will address corporations as seen through the eyes of the early scholars, and their characteristics and classifications, as portrayed by them.

The third subtopic of the historical overview will be devoted to breakthroughs within the history of corporations, and will address the main landmarks that might be considered as prompts that led to the change, the development, and proliferation of the corporation to date. It will address mainly the East India Corporation as it was maintained to be the mother of modern corporations, and also the South Sea Company and the Bubble Act and how they significantly influenced the corporation. Moreover, the proliferation of trusts will be addressed, in order to understand how that led to the development of antitrust laws and to identify the real reason behind the enactment of those laws in certain jurisdictions.

In addition to that, and since this book is mainly concerned about mergers, the history of mergers will be addressed as a breakthrough in the history of corporations, and also the patterns of mergers transactions throughout history to date will be discussed, in order to understand what triggered incentives that led to the formation of the merger waves. Multinational corporations will also be addressed. Finally, the fourth subtopic of the historical overview will address the immemorial relation between corporations and states, and it will be scrutinized through the history of the corporation to understand how the state controlled corporations by means of laws. In addition to that, it will seek to understand how that relation started mainly under feudalism and how it proceeded to date and even how corporations are not just an idle powerless party in that relation. 
Delving into the first topic, the historical overview, will undoubtedly lead to a better understanding of corporations and how they are the way they are, and why they are the way they are, and that is an essential step toward understanding how they might be changed for the good in the future. Therefore, a better understanding of those issues addressed in that first topic is undoubtedly a prerequisite to delving into the following parts of this book.

Subsequently, the second main topic of this chapter i.e. demystification of mergers, will include three subtopics. The first topic is simply definition of mergers, and how mergers could be distinguished from other technical terms like acquisition and consolidation. The second subtopic will identify the different types and classifications of mergers, from economic, structural, and procedural, and financial perspectives, and it will address also other restructuring forms and trends, and growth options that are used by corporation as an alternative to mergers. Following that, the third subtopic will scrutinize merger dynamics. It will address each step in that dynamic, starting from the preparation step until the closing of the merger transaction, passing through all the other steps such as due diligence, valuation, structuring, and financing the transaction. The third subtopic will help in understanding the impediments that the merger transaction will face at the different stages of the transaction.

\section{HISTORICAL OVERVIEW}

Indeed, history is a good and efficient tool that could inform and guide every researcher about his topic. To be more precise, reverting back and scrutinizing the history of any topic will be beneficial on two dimensions; the first is the formation of the subject itself, and the second is the development of its main characteristics. ${ }^{11}$ Moreover, it undoubtedly true that history should be deeply scrutinized to explore all the intrinsic, as well as extrinsic, factors that might contribute to the creation of one of the modern institutions. ${ }^{12}$ Obviously, to better understand corporations it will be very helpful to dig deep into the history until reaching its origins i.e. the seeds not only the roots.

Unfortunately, early historians wrote most of the history of the corporation, and because none of them were legal professionals, many

11 John Smith \& Raymond O’Brien, Conflict of laws at 10 (2nd ed., Cavendish. 1999).

12 Francis Fukuyama, The Origins of Political Order at 1 (Farrar, Straus and Giroux. 2011). 
of them did not consider the differences between a corporation as an institution and a merchant who is doing business in his own name. It has also been noted that the resources that might draw a full legal picture of business in the Middle Ages, are not available. ${ }^{13}$ In addition to that, even the medieval sources should not be recognized as reliable, because mainly unqualified "non-historians-soldiers, explorers, missionaries, clerics, and businessmen," wrote most of them. ${ }^{14}$

Though historians used to simplify their work by subjects (i.e. economic, social, and cultural), ${ }^{15}$ it is not easy to find a historian who scrutinized history from a legal perspective. It is noteworthy that even law scholars might be excused for their modest efforts, due to the fact that no reliable data concerning the history of modern organizations were recorded before the end of the 13th century, for instance the records of the King's Court in the United Kingdom of Great Britain and Northern Ireland (hereinafter UK), ${ }^{16}$ started to be uniform and on a permanent basis only after the 12 th century. ${ }^{17}$

Law scholars did not even start to write about corporations until more than four centuries later; some claimed that the first lawyer to write about the law of corporations was William Sheppard, ${ }^{18}$ his first book being published in London in 1659 and his second book on the same subject after his death in 1702. ${ }^{19}$ Meanwhile, it has also been claimed that the reports of Sir Edward Coke ${ }^{20}$ were the first legal writings to discuss the law of

\footnotetext{
13 A. T. Cater, A History of English Legal Institutions at 259 (4th ed., Butterworth \& Co. 1910).

14 Gene W. Heck, Charlemagne, Muhammad, and the Arab Roots of Capitalism at 1 (W. de Gruyter. 2006).

15 Fernand Braudel, Civilization and Capitalism, 15Th-18Th Century: The Perspective Of THE World at $17 \S 3$ (Harper \& Row. 1981).

16 A wide range of official names were used to refer to what is now known as the United Kingdom of Great Britain and Northern Ireland, especially due to the changes in is territories over the history, therefore UK will be used hereinafter instead of all of these names.

17 Harold J. Laski, The Early History of the Corporation in England, 30 HaRVARD LaW Review 561, at 562 (1917).

18 William Sheppard (1595-1674) worked as a clerk at the upper bench in the UK and then as a sergeant-at-law, and later he was directly involved in corporate issues while drafting the charters granted to towns as incorporated corporations.

19 Amasa M. Eaton, The First Book in English on the Law of Incorporation, 12 The Yale Law Journal 259, at 259-260 (1903).

20 Sir Edward Coke (1552-1634) worked as a lawyer then as Attorney General, and later as a Chief Justice at two courts, and finally as a statesman. For more details about his life and ideas see Edward Coke, The Selected Writings AND Speeches of Sir Edward CoKe at xxiv-xxvi (Steve Sheppard ed., Liberty Fund. 2003). For a brief overview about his works see id. at xxvii-xxix.
} 
corporation in detail, especially his writing on the Sutton Hospital Case, ${ }^{21}$ which was first published in $1614 .^{22}$ In his decision on that case, while he was refuting all the arguments that were submitted in the case before him as a judge, he revealed all the main characteristics of corporations at his time.

Actually, it has been asserted that most authors' works during the Middle Ages are used "to describe, not to define." 23 That could be easily identified in the early efforts of the law scholars; while they were trying to contribute to the law of corporations they tended to explain it, not distinguish it. Regrettably but true, most if not all the early works of history are more interested in describing the development of an idea rather than trying to analyze it. ${ }^{24}$ Furthermore, legal scholars' efforts during the Middle Ages were considered modest to a large extent; they just drew pictures of what they saw without any analysis or critical thinking. For instance, it was common in that period to put a lot of effort into describing the different types of corporations, like sole and aggregate corporations, ${ }^{25}$ while there are no actual differences between them. They even made an effort to describe the corporate seal as one of the most important characteristics of the corporations, while this "great antiquity" practice of using the seal could be traced back to the Roman Empire. ${ }^{26}$

Accordingly, and based on the scarcity of analytical resources, and due to the nature of this discussion i.e. giving a historical introduction, the discussion here will be more descriptive and less analytical. The following discussion will include different claims concerning the origin of the corporation as an idea, and several early efforts to describe the corporation, and its main characteristics and classifications. Moreover, it will try to light the way ahead to spot some significant milestones during the breakthroughs of corporation history, which are mainly the early developments and how trusts, as a form of business institution, led to the introduction

\footnotetext{
21 Sutton Hospital Case (1612) 77 Eng. Rep. 960.

22 COKE, The Selected Writings and Speeches of Sir Edward Coke, supra note 20, at xxvii.

23 Joan C. Williams, The Invention of the Municipal Corporation: A Case Study in Legal Change, 34 AMERICAN University LAW REVIEW 369, at 381 (1985), citing Susan Reynolds, An Introduction to the History of the English Medieval Towns at 97 (Clarendon Press. 1977).

24 Richard Henry Tawney, Religion and the Rise of Capitalism, a Historical Study at 6 (Penguin Books Ltd. 1938).

25 For more details about early classifications and different types of corporations see infra p.20.

26 Samuel Williston, History of the Law of Business Corporations before 1800, 2 Harvard LaW Review 105, at 117 (1888).
} 
of antitrust laws. The discussion will also include other milestones such as merger waves, multinational corporations, and the relation between corporations and the state.

\section{Origin of the Corporation}

This discussion will show that there is a great debate between scholars concerning the origin of the idea of corporation, and how each civilization contributed to its development, so it might be more meaningful to call it the debate of origins and developments. While some argued that the idea was born during the Roman Empire and then borrowed and developed by Muslims, others claimed that Muslims created the first modern corporate form, and that the Italians introduced it to Christian Europe. Alternatively, others argued that the modern corporation was an Italian invention basically invented to satisfy the deep needs of their daily trade practices. In addition to that, some argued that Jews were the fuel of all economies they lived in, and they profoundly contributed to the proliferation of the idea and development of the modern corporation.

All of those claims will be scrutinized in a chronological order because no single explanation can give the full picture of the origin and development. Though, it is noteworthy here that the following discussion will be limited to the origin and the development of the corporation until the end of Middle Ages at the 16th century, because the following periods will be dissected during our later discussions of the corporations characteristics, classifications, and breakthroughs. Moreover, the origin of the stock exchange, banks, and other institutions will be outside the scope of the discussion.

\section{(a) Greek and Roman origins}

Numerous authors ${ }^{27}$ argued that the first seed of the corporation idea was credited to Numa Pompilius ${ }^{28}$ and all of them cite only Sir William

27 Joseph K. Angell, Treatise on the Law of Private Corporations Aggregate at 34-35 (Samuel Ames \& John Lathrop eds., Little, Brown 7th ed., rev., corr., and enl. / ed. 1861). Douglas Arner, Development of the American Law of Corporations to 1832, 55 Southern Methodist University Law Review 23, at 25-28 (Winter 2002). Leonard W. Hein, The British Business Company: Its Origins and Its Control, 15 The University of Toronto LaW Journal 134, at 135 (1963). Williston, Harvard Law Review, supra note 26, at 106. John Micklethwait \& Adrian Wooldridge, The Company: A Short History of a Revolutionary Idea at 4 (Modern Library. 2003).

28 Numa Pompilius was the legendary second King of Rome, and he was born on the day of Rome's founding (traditionally, April 21, 753 BC). 
Blackstone in his famous work the Commentaries on the Laws of England, ${ }^{29}$ although Blackstone himself was citing another ancient Greek historian, Plutarchus, ${ }^{30}$ who fully recognized the idea of what Numa really created. According to Plutarchus, Numa's idea was to make a separate legal personality for two groups of people, namely Sabines and Romans, and then he developed the idea to make a separate legal personality for subgroups of traders and workers. ${ }^{31}$ Moreover, the idea of tying corporations to the basic unit of the society, i.e. the family, was also attributed to the Romans. ${ }^{32}$ Meanwhile, it was also claimed that such separation or categorization of groups of people into uniting associations could be traced and attributed to the Greeks. ${ }^{33}$

To the contrary, others alleged that it was reported, even before the Greeks and Romans, that there were some forms of corporations during the period between 2000 and $1800 \mathrm{BC}$, whereas it was maintained that an Assyrians group of investors collected 26 pieces of gold and entered into an agreement with a merchant called Amur Ishtar, who himself paid his share as four pieces of gold, to form an association to be run by Amur himself, and that association stood for four years. ${ }^{34}$

Moreover, it has been claimed that the Phoenicians, followed by the Athenians, borrowed the ideas of the Assyrians and brought them to the sea in their trading voyages, and thus spread them to other civilizations. ${ }^{35}$ In the same context, it is noteworthy that the contribution of the Athenians became incorporated into the laws of Solon, ${ }^{36}$ and according to that law it was permissible to form a private corporation more easily than under the Romans rules. ${ }^{37}$

29 William Blackstone, Commentaries on the Laws of England in Four Books $§ 1$ (J.B. Lippincott Co. 1893).

30 Lucius Mestrius Plutarchus, born in AD 46 and died AD 120, was a Greek historian, biographer, and essayist.

31 Blackstone, Commentaries on the Laws of England in Four Books, supra note 29 , at $468-469$.

32 Micklethwait \& Wooldridge, The Company: A Short History of a Revolutionary Idea, supra note 27, at 4.

33 Angell, Treatise on the Law of Private Corporations Aggregate, supra note 27, at 35; Williston, HaRVARD LAW REviEW, supra note 26, at 106.

34 Albert Venn Dicey, Lectures on the Relation Between Law \& Public Opinion In ENGLAND During the Nineteenth CENTURY at 245 (Macmillan. 1920).

35 Micklethwait \& Wooldridge, The Company: A Short History of a Revolutionary Idea, supra note 27, at 3-4.

36 These laws were attributed to Solon $638 \mathrm{BC}-558 \mathrm{BC}$, who was an Athenian statesman and lawmaker.

37 Angell, Treatise on the Law of Private Corporations Aggregate, supra note 27, at 35; Arner, Southern Methodist University Law Review, supra note 27, at 25. 
It has been reported that as the Roman Empire expanded, and the trusted Roman tax collectors were not capable enough to collect the taxes over that huge land, a new form of corporation to collect the taxes was invented. ${ }^{38} \mathrm{It}$ was also reported that during this era, the corporation and its principles was less developed or ran through dramatic changes, and by the end of this era the result was limited to a fairly fragile institution, that led some to call it a "mere group of individuals." 39 On the other hand, it has been claimed that by the end of the Roman era, there were different forms of corporations like works and trade associations i.e. "guilds," 40 and a "merchant empire." 41

\section{(b) Islamic origins}

Many authors held that despite the fact that Islam did not contribute to the creation of many commercial and banking instruments, due to the prohibition of usury in Islam, Islam was considered the origin of many corporations' practices, which were then borrowed by the Italians and introduced in Europe. Moreover, others claimed that Muslim scholars had worked hard to structure and tailor corporate forms and even banking tools to fit into Islamic norms, and these designs and structures were borrowed by Italians and introduced into Christian Europe, where usury was also prohibited, and it helped Europe to survive the "devastating socioeconomic policies." 42

To be more precise, because Islam banned usury, rich Muslims who have assets but do not want to run trade themselves, cannot lend their money to merchants for interest. It has been reported that Muslims created what was known later in Italy as commenda, which resembles a special purpose vehicle or a corporation used to pool money, and then others managed it and traded abroad, and after the trading voyage they shared profits and losses. ${ }^{43}$

It is noteworthy that those early trading voyages were mentioned

38 Micklethwait \& Wooldridge, The Company: A Short History of a Revolutionary Idea, supra note 27, at 4.

39 Michael Ivanovitch Rostovtzeff, The Social and Economic History OF THE Roman EMPIRE at 160 (Clarendon Press. 1926); and see generally ARNOLD Hugh Martin Jones, The Roman Economy: Studies in Ancient Economic and Administrative History (Rowman and Littlefield. 1974).

40 For more about the development of guilds in the Middle Ages see Arner, SOUTHERn Methodist University LAW ReVIEW, supra note 27, at 26.

41 Micklethwait \& Wooldridge, The Company: A Short History of a Revolutionary Idea, supra note 27, at 7.

42 Heck, Charlemagne, Muhammad, and the Arab Roots of Capitalism, supra note 14 , at 5-7.

43 John Braithwaite \& Peter Drahos, Globalisation of Corporate Regulation and 
in the Holy Quran; it was mentioned in the Quraish chapter that the people of Quraish, a group of individuals residing in the city of Mecca in the area that is now known as the Kingdom of Saudi Arabia, were united and their unity was due to their trading voyages. They used to arrange trading voyages twice per year, one to Yemen in the winter and the other in summer to Bilad Al-Sham or what was then named Greater Syria. ${ }^{44}$

Despite the fact that usury was banned in Islam and the fact that it was clear that the commenda was literally a form of corporations, others wrongly argued that it was just a type of contract by which rich Muslims would lend merchants money to finance their trading voyages for a large amount of interest in return. ${ }^{45}$ To the contrary, some other scholars argued that the commenda was developed by means of the invention of the limited liability concept, whereas the non-practicing or inactive members of the commenda were granted a limitation of the liability to their pooled money. For instance, in Italy no individual was liable for the loss of commenda after the year $1408 .{ }^{46}$

On the other hand, it was wrongly claimed that the corporation form that was created by Muslims was suffering from several limitations required for growth and thus was not developed further. These claims were based on the argument that most of the transactions between Muslims were not written, and in addition to that the Islamic inheritance rules led to the division of the corporate shares to too many successors after the death of the principal. Moreover, they argued that that was not the case in Christian Europe, because the principal was allowed to nominate a single beneficiary after his death. ${ }^{47}$

In fact, these claims can be easily refuted. First concerning the claim of unwritten transactions, contrary to that claim, and according to the Holy Quran, Muslims should write all their credit transactions. As per verse no. 282 of Al-Baqarah chapter of the Holy Quran, Muslims are instructed not only to do this, but also that verse stipulates that all sales transactions should also be witnessed by trusted people in addition to the writing

Corporate Citizenship, in International Corporate Law Annual at 7 (Fiona Macmillan ed. 2003).

44 Quraish chapter, the Holy Quran.

45 Fernand Braudel, Civilization and Capitalism, 15Th-18Th Century: The Wheels of COMMERCE at 122 § 2 (Harper \& Row. 1981).

46 Colin Arthur Cooke, et al., Corporation, Trust and Company: An Essay in Legal History at 46 (Manchester University Press. 1950).

47 Micklethwait \& Wooldridge, The Company: A Short History of a Revolutionary Idea, supra note 27, at 5-6. 
requirement, and the case is the same even for insignificant and minor transactions.

Moreover, concerning the inheritance rules, during the same early periods of Islam there were Jewish inheritance rules, and those rules were applied to both Jews and Christians. Those rules were not only similar to a great extent to the Islamic rules of inheritance, but also allowed more family members to take shares of the dead person's estate, for example in Islam neither brothers nor sisters had a share in the estate whenever the dead person had one son or more, while under the Jewish rules, brothers had a share in such a case.

Accordingly, the division of corporate shares to too many successors was imposing limitations, if true, on the development of the corporation in Christian Europe, more than in Muslim countries. On the contrary, taking into account that Islam does not impose any limitation on the sale of the corporate shares, whether inherited or not, one may argue that the division of the corporate shares is expected to contribute to the development of new corporate practices and their expansion.

In the same line, others claimed that Muslim trading practices and forms of corporation were developed and expanded to a very large geographic area, throughout the Mediterranean and to the east in the Indian Ocean and China, and that the Muslim trading community steadily took the whole Byzantine Empire. ${ }^{48}$ It is also reported that thousands of Muslim merchants were traveling to do business and trade in China even before the famous Italian merchant Marco Polo found his way to China in the 14 th century. ${ }^{49}$

Furthermore, it was even maintained that not only borrowing the corporate structure and ideas from Muslims was a success to others dealing with them, but it was also a great success to conclude deals or transactions with them and get gold or even Syrian or Egyptian currency i.e. Dinar from them, because all these currencies were acceptable everywhere. Merchants used these currencies to purchase silk and salt from Byzantium and resell them again to Muslims in what was known as a "triangular transaction." 50

48 BRaudel, The Wheels of Commerce, supra note 45, at 584; BRAUdEL, The Perspective of the World, supra note 15, at 108.

49 Micklethwait \& Wooldridge, The Company: A Short History of a Revolutionary Idea, supra note 27, at 5.

50 Braudel, The Perspective of the World, supra note 15, at 107. 


\section{(c) Italian origins}

It has been claimed by many scholars that capitalism ${ }^{51}$ was a Western invention, particularly in the same Italian cities that were trading with Muslims, ${ }^{52}$ thus it could be contended that the seed of capitalism could be traced to Muslims. It has been further reported that the early corporations that were created in 9th century in the dynamic cities of Italy, like Venice, Genoa, Amalfi, Gaeta, and Pisa, were structured in the same manner as the Muslims' corporation, and these same structures were designed especially for the good of inactive rich Muslims, and even for the same purpose of the single trading voyage. ${ }^{53}$

By the second half of the 11th century, precisely during the period of 1072-1073, the commenda or colleganza, ${ }^{54}$ as a form of trading voyage corporation, started to appear, and was then developed into two forms: the first was unilateral colleganza whereby the inactive investor socius stands financed the whole voyage and the party who managed the trade socius procertans paid nothing for 25 percent of the profits; and the second was bilateral colleganza where the socius procertans advanced a 25 percent share and then the profit was shared between them equally. ${ }^{55}$

Until this stage, it may be claimed that nothing was added to the Muslims' contributions to the development of the corporation. However, it has been reported that by the 12 th century a somewhat distinctive form of corporation was developed in Florence, which was the compagnia. It was first developed as a family business, and was mainly based on the joint liability of all the family members, and in that regard it is unsurprising to know that the term compagnia was a combination of the two Latin words cum and panis, and their meaning is "breaking bread together." 56

As was previously mentioned, getting gold currency from Muslims was a great success, and it is also reported that in Florence, as a development in the 13th century, the Italians started to coin their own gold currency as early as 1250 and in Venice in $1284 .{ }^{57}$ At a later stage, in the 13 th century,

51 Braudel, The Wheels of Commerce, supra note 45, at 237. Braudel noted that the word "capitalism" started to be used at the beginning of the 20th century and was defined as known today as the contrary of socialism.

52 Heck, Charlemagne, Muhammad, and the Arab Roots of Capitalism, supra note 14 , at 4 .

53 Micklethwait \& Wooldridge, The Company: A Short History of a Revolutionary Idea, supra note 27 , at 7.

54 The two terms were used differently in the Italian cities.

55 BRAUDEL, The Perspective of the World, supra note 15, at 129-130.

56 Micklethwait \& Wooldridge, The Company: A Short History of a Revolutionary Idea, supra note 27, at 7-8.

57 BRAUDEL, The Perspective of the World, supra note 15, at 110-112. 
it has been alleged that Italians came up with two inventions that were profoundly the pillars for the development of the corporation. The first invention was double entry bookkeeping, which was mainly enabled by the help of using Arabic numerals instead of Roman numerals. ${ }^{58}$ It is noteworthy that the Italian Fra Luca Parioli is credited as the first to invent and use double entry bookkeeping. ${ }^{59}$

To better understand how the double entry bookkeeping invention contributed to the development of the corporation, it has been reported that a "Genoese merchant would record money sent to his agent in Bruges as 'paid' in his accounts, while the latter put down the amount as 'received.' And rather than sending coins, the bigger merchants began to trust each other with letters of exchange - a business that Italian banks would dominate. ${ }^{\prime 60}$ Accordingly, double entry bookkeeping was directly involved in increasing the trade activities and unquestionably in the development of the corporation as a means of trading activities.

Undoubtedly true, Fra Luca Parioli's invention directly guided the Italians to what was deemed as their second invention, which is the persona ficta i.e. the separation of the corporation's legal personality from its owner. ${ }^{61}$ In that regard, it was also argued that transferring the national debt into bonds was a later third Italian invention, which might be considered a financial revolutionary tool that helped European countries to succeed. ${ }^{62}$ In addition, it was also claimed that there was a fourth Italian invention in the 13th century, directly linked to the development of trade and corporations, which was the bill of exchange. ${ }^{63}$ Meanwhile others refuted that claim on the grounds that the bill of exchange was originally created by Muslims in the 12th century and was known as Saftaga, and it was created among other commercial tools invented during the same period, like the check for instance. ${ }^{64}$

Another two important forms of corporations were developed in

58 Braithwaite \& Drahos, Globalisation of Corporate Regulation and Corporate Citizenship, supra note 43 , at 5, 8 .

59 Dennis W. Carlton \& Jefrerey M. Perloff, Modern Industrial Organization at 11 (4th ed., Pearson. 2015).

60 Micklethwait \& Wooldridge, The Company: A Short History of a Revolutionary Idea, supra note 27 , at 8 .

61 Braithwaite \& Drahos, Globalisation of Corporate Regulation and Corporate Citizenship, supra note 43 , at 5.

$62 \quad I d$. at 4.

63 Braudel, The Perspective of the World, supra note 15, at 112.

64 See generally Mofizur Rahman, Financial Transactions With Commercial Papers in the Light of Islamic Shariah, 3 Annual ReSEARCH Journal of THE InTERNATIONAL IsLAMic University CHITTAGONG 91 (2006). 
Genoa, in the first half of the 14th century; the first was the compere and the second was the maone. Both forms of corporation were created to run government tasks, and generally speaking not all scholars agreed on their nature and whether any of these forms could be considered a corporation. The first form was an association that comprised shares owned and operated by private individuals, and the second form was literally a loan to the government. ${ }^{65}$ While the first form was a corporation to a large extent, the second one might be classified just as a loan agreement between government and private individuals, not as a corporation.

By the end of the 14th century some of the Italian cities like Venice, for example, were undoubtedly flourishing economically, ${ }^{66}$ and booming to the extent that it has been reported that all European countries were borrowing its corporate forms, structures, and techniques. A very important example was Germany's Magna societas, which was structured as a merger between three family businesses, with a principal office in Ravensburg, which was a small town in Swabia, ${ }^{67}$ and with almost 200 branches in many other cities like Barcelona, Genoa, Vienna, and Paris. ${ }^{68}$

Undoubtedly true, the flourishing of the corporations in Italy was fueled not only by the rich people that owned shares in the corporations, but also by the organized lending institutions that were raised at the same time; for instance the banks ${ }^{69}$ or what was known at these times as the banchi. ${ }^{70}$ It has been reported that banks also expanded through branches and very complicated networks throughout many cities located in different countries. ${ }^{71}$ The role of banks in financing the development of the corporation will be addressed shortly during the next discussion of the Jewish contributions.

By the beginning of the 16th century there was an urgent need to limit the liability of some family members that were not engaged in the practice of management or trade i.e. the inactive party. Accordingly a new form of corporation started to exist, which was the accomandita, and the

\footnotetext{
65 Braudel, The Wheels of Commerce, supra note 45, at 440.

66 Braudel, The Perspective of the World, supra note 15, at 119.

67 BRAUdeL, The Wheels of Commerce, supra note 45, at 436.

68 Micklethwait \& Wooldridge, The Company: A Short History of a Revolutionary Idea, supra note 27, at 12.

69 Micklethwait \& Wooldridge, The Company: A Short History of a Revolutionary Idea, supra note 27 , at 8.

70 The word banchi was the origin of the word "bank," and it was named after the Italian word banco, which means "bench" in English, and it was used to indicate the bench that was used by lenders in Italy to sit on or stand behind.

71 Micklethwait \& Wooldridge, The Company. A Short History of a Revolutionary Idea, supra note 27, at 162.
} 
accomandita gradually replaced the aforementioned family compagnia. ${ }^{72}$ As an inevitable result of these developments, the sea trading voyages or what some scholars named "naval capitalism" significantly expanded during that period. ${ }^{73}$

\section{(d) Jewish contributions}

The fact throughout history is that the Jewish merchants' network was expanding and it reached almost every country on the planet. ${ }^{74}$ For instance, it was reported in the "Cairo Geniza Documents"75 that in the 9th century the Jewish network spread from Egypt to Ethiopia in Africa and to India in Asia, using the means and channels that were developed by Muslims. ${ }^{76}$ Additionally, it was reported in the 10 th century that very rich Jewish families were involved in various business like trading, banking, and even tax collecting in many jurisdictions such as Egypt, Iran, Iraq, etc. $^{77}$

It is undoubtedly true that any minority throughout history, whether due

72 BraUdel, The Wheels of Commerce, supra note 45, at 438. He reported that the first accomandita ever recorded was recorded in Florence on May 8, 1532.

73 Micklethwait \& Wooldridge, The Company: A Short History of a Revolutionary Idea, supra note 27, at 18.

74 BRAUDEL, The Wheels of Commerce, supra note 45, at 157.

75 For more details about the "Cairo Geniza documents" see Shelomo Dov Goitein, A Mediterranean Society: The Jewish Communities of the Arab World as Portrayed in the Documents of the Cairo Geniza (University of California Press. 1999); Yale University Library Introduction to the documents: "The Cairo Geniza is a collection of some 300,000 Jewish manuscript fragments that were found in the geniza or storeroom of the Ben Ezra Synagogue in Fustat or Old Cairo, Egypt. These manuscripts outline a 1,000-year continuum ( 870 CE to 19th century) of Jewish Middle-Eastern and North African history and comprise the largest and most diverse collection of medieval manuscripts in the world. The Genizah texts are written in various languages especially Hebrew, Arabic and Aramaic mainly on vellum and paper, but also on papyrus and cloth. In addition to containing Jewish religious texts such as Biblical, Talmudic and later Rabbinic works (some in the original hands of the authors), the Genizah gives a detailed picture of the economic and cultural life of the North African and Eastern Mediterranean regions, especially during the 10th to 13th centuries. It is now dispersed among a number of libraries, including the libraries of Cambridge University and the University of Manchester."

76 Braudel, The Wheels of Commerce, supra note 45, at 157, citing SHaUl Shaked et al., A Tentative bibliography of Geniza documents: Prepared UNDER THE DIRECTION OF D. H. BANETH AND S. D. GoiteIn (Mouton \& Co., and École Pratique des Hautes Études. 1964).

77 Subhi Y. Labib, Capitalism in Medieval Islam, 29 The Journal of ECONOMIC History 79, at 84 (1969). 
to nationality or religious background, as in the case of the Jews, did unite and form a group for many purposes: to feel safer, to share the benefits of the group, and to support each other. ${ }^{78}$ Based on that fact, it could be claimed that the members of the minority group might share same practices and they might spread their practices in the community or communities where they lived. In that context, scholars have admitted that thousands of causes contributed to the modern structure of corporations and the economy, with diverse examples including the discovery of America and the industrial revolution, and they also affirmed that capitalism would not be as it is if the Jews had not been involved and added to the economy. ${ }^{79}$

Scrutinizing the legal environment, and a cursory overview of the art of the Middle Ages, will reveal the fact that usury was forbidden in most societies and usurers were tortured and exiled. ${ }^{80}$ For instance, Dante Alighieri ${ }^{81}$ in his poem Inferno, ${ }^{82}$ which was published in 1314 , classified hell into circles and then he mentioned that usurers were sent to be punished into the core of the 7 th circle, and people in that circle would be punished by "flaming sand with fiery flakes raining from the sky." 83

In addition to the unity of the Jews due to their minority status, they were almost exiled by many societies during these early times, mainly because they were practicing usury, and that was banned by most nations. Being exiled from many societies and relocating from one place to another led to an inevitable result, which was that the Jews contributed to and affected the development and the structure of the corporation throughout history, as well as the economy in general, not only because they used usury practices to finance economic activities, but also because they might have borrowed some of the practices from every society they lived in, and then spread them again when they settled in another.

\section{Early Characteristics and Classifications of Corporations}

Corporation, incorporation, body politic, and body incorporate are all terms that were used interchangeably, by William Sheppard and many

\footnotetext{
78 BRAUdEL, The Wheels of Commerce, supra note 45, at 165.

79 Werner Sombart, The Jews and Modern Capitalism at 9 (Mortimer Epstein trans., Batoche. 2001).

80 Micklethwait \& Wooldridge, The Company: A Short History of a Revolutionary Idea, supra note 27, at 8.

81 Dante Alighieri (1265-1321) was a prominent Italian poet during the Middle Ages.

82 The word "inferno" means hell in the Italian language.

83 Dante Alighieri, Inferno at Canto XIV (National Library Company. 1909).
} 
other early scholars, while writing about corporations. ${ }^{84}$ They used to describe all of these terms as an assembly that gathers many persons into one artificial person. ${ }^{85}$ In fact this is comparable to a large extent to the current brief description of the modern corporation. ${ }^{86}$ They believed that the artificial person is the perpetual successor of the group of all people, resembling their united soul; ${ }^{87}$ and even Sir Edward Coke concluded that a corporation is nothing but a soul. ${ }^{88}$ More than 200 years later, Chief Justice John Marshall repeated almost the same description by saying that the "corporation is an artificial being, invisible, intangible, and existing only in contemplation of law." 89

In the same descriptive context, most of the earlier law scholars repeatedly followed each other and mentioned the same main characteristics of corporations. ${ }^{90}$ Meanwhile, it is noteworthy that while they were repeating each other, they were also describing the corporations' charters available before them, and that might sometimes have led to contradicting ideas or at least slight differences or limitations. However, these main corporations' characteristics, described by most of them, can be summarized as follows: (1) generally the corporation has the right of perpetual succession, but in a range of instances it was granted a limited succession period, ${ }^{91}$ and sometimes it has to be dissolved by the death of all its partners; ${ }^{92}$ (2) generally the corporation has the right to sue and be sued, but for instance the right to sue foreign corporation was unknown until it was first granted in the

84 Angell, Treatise on the Law of Private Corporations Aggregate, supra note 27, at 3; Eaton, The Yale Law Journal, supra note 19, at 265.

85 Arner, Southern Methodist University Law Review, supra note 27, at 42 (Winter 2002). Angell, Treatise on the Law of Private Corporations Aggregate, supra note 27, at 20.

86 Joseph Stancliffe Davis, Essays in the Earlier History of American Corporations at 5 (Harvard University Press. 1917).

87 Hein, The University of Toronto LaW Journal, supra note 27, at 134.

88 Sir Edward Coke Reports Volume 10 the case of Sutton's Hospital p.33a.

89 Trustees of Dartmouth College v. Woodward, 17 U.S. (4 Wheat.) 518 (1819).

90 Coke, The Selected Writings and Speeches of Sir Edward Coke, supra note 20, at 366-367; Blackstone, Commentaries on the Laws of England in Four Books, supra note 29, at 475-476; Williston, HARVARD LAW REvIEW, supra note 26, at $117(1888)$.

91 That was the norm, but some other times it was granted a limited succession period. For more details see Hein, The University of Toronto Law Journal, supra note 27 , at 139.

92 Blackstone, Commentaries on the Laws of England in Four Books, supra note 29, at 485; Arner, Southern Methodist University Law Review, supra note 27 , at 37 . 
UK in $1872 ;{ }^{93}$ (3) generally the corporation has the right to purchase and to hold lands and all kinds of assets, ${ }^{94}$ likewise some other scholars mentioned that it could not purchase or hold lands, ${ }^{95}$ (4) the corporation has the right to have a seal; (5) generally the corporation has the right to issue internal ordinances or by-laws; (6) there is an obligation on the corporation to allow government officials and others to investigate it; (7) a corporation is not allowed to form another corporation, ${ }^{96}$ but some scholars claimed that a corporation could be created by another corporation, and for instance the king is a corporation who has the power to form other corporations; ${ }^{97}(8)$ a corporation could be dissolved by Act of Parliament, by death of all the partners, by voluntary forfeit to the king, or by the courts as a penalty, ${ }^{98}$ while other scholars argued that this was limited only to Parliament. ${ }^{99}$

Scrutinizing, or just taking a closer look at what was mentioned in these earlier works, will easily lead to the conclusion that they were superficial to a large extent. For instance, as regards the right of the corporation to sue and to be sued by third parties, none of these works discussed the concept in detail. To sue a corporation before 1826, a third party would have to sue all the partners in their exact and full name otherwise the suit would be unacceptable, and the right to sue and be sued under its own name or in the name of its representative was granted to some corporations, then it was totally forbidden, then it was granted again for some corporations

93 Smith \& O'Brien, Conflict of Laws, supra note 11, at 184, mentioning that in 1872, it was established that a foreign corporation could be sued in England.

94 Blackstone, Commentaries on the Laws of England in Four Books, supra note 29 , at 475 .

95 Hein, The University of Toronto Law Journal, supra note 27, at 141 (1963). James Grant, A Practical Treatise on the LaW of Corporations in General: As Well Aggregate as Sole at 108 (T. \& J.W. Johnson. 1854). Mentioned that corporations cannot hold or purchase land.

96 William Sheppard, Of Corporations, Fraternities, and Guilds, or, A Discourse Wherein the Learning of THe LaW Touching Bodies-PolitiQue is Unfolded SheWing the Use and Necessity of that InVention, the AntiQuity, Various Kinds, Order and Government of the SAME; Necessary to be KNOWN Not Only of all Members and Dependants of Such Bodies; but of all Professours of our Common Law; with Forms and Presidents of Charters of Corporation at 112 (H. Twyford, T. Dring, and J. Place. 1659).

97 Grant, A Practical Treatise on the Law of Corporations in General: As Well Aggregate as Sole, supra note 95, at 109-110.

98 Blackstone, Commentaries on the Laws of England in Four Books, supra note 29, at 485; Arner, Southern Methodist University Law Review, supra note 27 , at $37-38$. 129.

99 ShePPARD, Of Corporations, Fraternities, and Guilds, supra note 96, at 
starting from 1826, and by 1857 most of the corporations was granted that right permanently. ${ }^{100}$

In the same context, some scholars mentioned that the corporation was granted its existence by four means: (1) by the common law, (2) by a charter issued by the king, (3) by an Act of Parliament, and (4) by prescription. ${ }^{101}$ Meanwhile others claimed that the corporation might be created by a fifth means, which is a corporation made by another corporation, ${ }^{102}$ and other scholars even asserted that some forms of corporations created themselves by themselves, for example many towns were created as corporations by themselves. ${ }^{103}$

It might be surprising that a political or a community unit like a town was classified at that time as a corporation, but that was the reality in the Middle Ages. In addition to that, most of the scholars at that time devoted a big portion of their writing to identifying who might be incorporated or granted the right to be a corporation, for instance William Sheppard cited the following examples: city, village, borough, town, parish, hospital, traders, free men, existing corporation, among others. ${ }^{104}$ The fact that was cited by William Sheppard, which is that a pre-existing corporation might be granted the right to be reincorporated, could be interpreted as being that corporations were allowed to be reincorporated or restructured, and that could be considered as an early sign that corporate restructuring was known and legally permitted.

Concerning the early attempts to classify corporations, they were almost the same classifications, and most of the scholars were just repeating each other. For instance, in the early attempts by scholars to classify corporations, with regard to their subject, they distinguished between sole and aggregate corporations, ${ }^{105}$ on the other hand Romans

100 Hein, The University of Toronto Law Journal, supra note 27, at 142-143.

101 CoKe, The Selected Writings and Speeches of Sir Edward Coke, supra note 20, at 363. Edward Atkins, The Law of Corporations Containing the Laws and Customs of all the Corporations and Inferior Courts of ReCORD IN England at 8-9 (Printed for Isaac Cleeve, Iohn Hartley, Francis Coggan, and Thomas Hodgson. 1702).

102 Grant, A Practical Treatise on the Law of Corporations in General: As Well Aggregate as Sole, supra note 95, at 18.

103 Eaton, The Yale Law Journal, supra note 19, at 266.

104 ShePpARD, Of Corporations, Fraternities, and Guilds, supra note 96, at $10-12$.

105 Joseph C. France, Principles of Corporation Law at 11 (M. Curlander. 1914). Blackstone, Commentaries on the Laws of England in Four Books, supra note 29 , at 469 . 
did not recognize sole corporations. ${ }^{106}$ Depending on the jurisdiction, corporations were classified into ecclesiastical and lay, ${ }^{107}$ and some even classify lay corporations into two categories eleemosynary and civil. ${ }^{108}$

Furthermore, with regard to the structure, or the creation of its "Body Politick" as it was called at that time, corporations were classified into elective and representative corporations. ${ }^{109}$ Regrettably but true, none of those classifications has an indication of or any importance in reality. Meanwhile it has been claimed that those classifications were very important at that time, ${ }^{110}$ however this claim did not mention any supporting evidence or even elaborations that might validate it.

At a later stage, during the 18th century, the classification of corporations started to be significantly different and it was even based on considerably different criteria. For instance, Adam Smith ${ }^{111}$ classified corporations into regulated, "private copartners," and joint-stock corporations. The regulated corporation, which was also known at that time as "Hamburg Company", was an association that united a group of individuals, and any qualified person could join at any time during its life, and each member of that corporation was allowed to perform trade activities, according to the corporation's internal rules but everyone had his own liability; ${ }^{112}$ in short this regulated corporation could be categorized as an equivalent to what was called in Adam Smith's time a "Guild."

It is noteworthy here that some authors argued that the direct linkage between the development of regulated corporations in the UK and the "guilds" in Italy could be easily identified and traced, while the development of the joint-stock corporations in the UK could not be traced back

106 Angell, Treatise on the Law of Private Corporations Aggregate, supra note 27 , at 20 .

107 France, Principles of Corporation Law, supra note 105, at 11; BLACKSTONE, Commentaries on the Laws of England in Four Books, supra note 29, at 470-471; Arner, Southern Methodist University Law Review, supra note 27, at 25, 36, emphasizing that Angell and Ames used this classification in their treatise in 1832, and Romans used the very same classification.

108 Williston, Harvard Law Review, supra note 26, at 105; France, Principles of Corporation Law, supra note 105, at 11; Blackstone, Commentaries on the Laws of England in Four Books, supra note 29, at 470-471.

109 Atkins, The Law of Corporations Containing the Laws and Customs of all the Corporations and Inferior Courts of Record in England, supra note 101, at 3.

110 France, Principles of Corporation Law, supra note 105, at 11.

111 Adam Smith was a Scottish philosopher and economist, and it was claimed that he was trained as a lawyer, for more details see Arner, SOUTHERn METHODIST UNIVERSITY LAW REVIEW, supra note 27.

112 Adam Smith, An Inquiry Into the Nature and Causes of the Wealth of Nations at 979-980 (Edwin Cannan ed., University of Chicago Press. 1976). 
to Italy. ${ }^{113}$ It was even claimed that by the beginning of the 15 th century the word "guildated" was synonymous with the word "incorporated." 114 Some authors called Adam Smith's regulated corporations "societates" and they gave some examples of it such as "the associations for working mines, salt-works, and for collecting taxes" and they elaborated more by mentioning that this category of corporations to a great extent resembled a natural person with regard to its rights, obligations, and liabilities. ${ }^{115}$ In the same context, it has been reported that the early examples of that category of regulated corporations were limited to local practices, but by the proliferation of sea voyages in the 16th century, the regulated corporation was granted the right to practice abroad, and it was even claimed that the East India Company was started as a regulated corporation. ${ }^{116}$

As a development to the regulated corporation idea, it was also reported that joining these overseas trading activities i.e. buying shares of the corporation, was on a voyage-by-voyage basis until 1614, then it became continuous, and by 1692 a dramatic change happened: members of the regulated corporation were no longer allowed to practice trade privately. ${ }^{117}$ By the end of the 17 th century, it could easily be identified that the joint-stock corporation was born as a new form of corporation.

Alternatively, some scholars reported that the joint-stock corporation, as a transferable shares concept, was not recognized by all legal systems at the same time, for instance Sweden recognized the joint-stock corporation more than 100 years later, in 1848. ${ }^{118}$ Moreover, joint-stock corporations were not involved in manufacturing to the same extent as trading, but they were involved at least in glass and paper manufacturing as early as 1642, at that time the "Glass Work" joint-stock corporation was formed in Massachusetts, and one other early example was the paper mill formed in 1706 in Pennsylvania. ${ }^{119}$

On the other hand, the distinction between "private copartneries" and joint-stock corporations, as recognized by Adam Smith, is similar to a great extent to the modern distinction between partnerships and

\footnotetext{
113 Hein, The University of Toronto Law Journal, supra note 27, at 143-144.

114 Williston, HaRvard LAW REviEW, supra note 26, at 108.

115 Id. at 107.

116 Id. at $109-110$.

117 Id. at 110.

118 Micklethwait \& Wooldridge, The Company: A Short History of a Revolutionary Idea, supra note 27, at 47.

119 DAVIs, Essays in the Earlier History of American Corporations, supra note 86 , at 94 .
} 
corporations. Undoubtedly true, Adam Smith distinguished between both of them on the basis that in the "private copartneries" the partners were not allowed to transfer their shares without the prior consent of all partners, and the liabilities of the partners was not limited to their shares. ${ }^{120}$

As early as the 16th century, other classifications were recognized by scholars, for instance they recognized that corporations could be classified according to their purposes and how they were connected to the government; in that regard some scholars classified corporations into private, public, ${ }^{121}$ and semi-public corporations. ${ }^{122}$ In that context, it was also recognized that such distinction is not so productive, because the fact that the end purpose of all corporations, either a private "civil" corporation or a public one, is good for people. ${ }^{123}$

An early example of the semi-public corporation was the military corporation. An interesting example was a corporation named "Take Trustees of the Road and Ferries from Newark to the Road leading from Bergen Point to Paulus Hook" and it was later known as "Jersey City." This corporation was incorporated on June 20, 1765 to maintain and keep in a good state the road between New York and Philadelphia, and in return it enjoyed the right to collect tolls and donations for its own private profitability. This corporation was an interesting example because it was reported that the corporation was created by way of a merger between many other corporations. ${ }^{124}$

In time all those early classifications were abandoned and were superseded by numerous classifications that were adopted by the different modern legal systems. It could be claimed that by the beginning of the 20th century the classifications were out of control. Though scrutinizing the modern classifications is outside the scope of this book, the following are just a few terms that are designated for some forms of corporations, classified according to the relation between the ownership and management: "small private companies, close companies, companies with concentrated ownership of shares, quasi-partnership companies, small and closely-held

120 Sмiтh, An Inquiry Into the Nature and Causes of the Wealth of Nations, supra note 112 , at 989 .

121 Williston, HaRvard LaW Review, supra note 26, at 110.

122 France, Principles of Corporation Law, supra note 105, at 14.

123 AtKIns, The Law of Corporations Containing the Laws and Customs of all the Corporations and Inferior Courts of Record in England, supra note 101, at 22 .

124 DAvIs, Essays in the Earlier History of American Corporations, supra note 86 , at $99-103$. 
companies, SMEs, owner managed companies, micro companies, large public companies, quoted companies, companies with fragmented ownership of shares, Berle and Means companies." 125

\section{Breakthroughs in Corporations' History}

Throughout the history of corporations there were landmarks, which might be considered as a prompt that led to the change, and to the development and proliferation of the idea itself. This section will be an overview of some of those landmarks, and will include a brief history of some corporations, namely the East India Company, as some named it the mother of modern corporation, and the South Sea Company, as it was the main cause for the biggest financial crisis during the early developments. Moreover, the following discussion will address "trusts" and how they are considered as the main cause for the creation of antitrust laws. Most importantly the discussion will address the history of mergers, scrutinizing the merger waves throughout history, and lastly it will include an overview on the development of multinational corporations.

\section{(a) The East India Company as the mother of modern corporations}

It has been claimed that the joint-stock corporation started to proliferate from the 16th century as a chartered corporation, during a time when the European monarchs started to create several joint-stock corporations. ${ }^{126}$ The following are just a few examples of these chartered joint-stock corporations, which were founded by the European monarchs during the 16th and 17th centuries: "Africa," "East India," "Hudson's Bay," "Levant," "Massachusetts," "Muscovy," "Virginia," and "The Company of Distant Parts." 127

It was also maintained that those early joint-stock corporations were just a development of the "regulated corporations" that were trading in the Middle Ages, ${ }^{128}$ and scholars further asserted that the two ideas were interrelated but generally speaking both are based on the same earlier idea of guilds, where all the members are allowed to practice trade or a certain

\footnotetext{
125 Ben Pettet, Company Law at 17 (2nd ed., Pearson Longman. 2005).

126 Joel Bakan, The Corporation: The Pathological Pursuit of Profit AND Power at 8 (Free Press. 2004); Micklethwait \& Wooldridge, The Company: A Short History of a Revolutionary Idea, supra note 27, at XVI.

127 Micklethwait \& Wooldridge, The Company: A Short History of a Revolutionary Idea, supra note 27, at 17.

128 Franklin A. Gevurtz, Globalization of Corporate Law: The End of History or a Never-Ending Story?, 86 WASHINGTON LAW REVIEW 475, at 481 (2011).
} 
profession separately but according to the internal rules. ${ }^{129}$ It was even claimed that the East India Company started as a "regulated corporation," and to be more precise the shareowners were allowed to trade under the supervision of the management of the corporation until that was prohibited in $1692 .{ }^{130}$

Meanwhile, it is noteworthy that some authors falsely claimed that the development of the idea of the chartered corporation was attributed to two main ideas borrowed from the Middle Ages, namely the idea of trading the corporations' shares and the idea of limited liability. ${ }^{131}$ On the other hand, other authors held that the limited liability idea was not developed until after the East India Company was even chartered, and it was also reported that one of the main reasons to develop limited liability was the high risk of the trading sea voyages; for instance between 1599 and 1601, four trading sea ships were sent to the East Indies and two of them were lost. ${ }^{132}$

In the same context, it was also claimed that even the idea of trading the corporations' shares on the stock exchange was based on the idea that investing in trading sea voyages had become permanent instead of single voyage as previously shown. ${ }^{133}$ To the contrary, it was maintained that the East India Company started by issuing shares for each trading sea voyage separately, and that continued for the first 12 voyages until it later switched to the idea of permanent shares. ${ }^{134}$ It was also professed that the idea of holding the corporations' shares for many voyages was borrowed from the Dutch, and even some authors argued that it took almost a century to be imitated by the English East India Company. ${ }^{135}$

The idea of investing in a series of trading sea voyages was first developed after the chartering of one of the Dutch corporations, which had the same name as the English East India Company - the Dutch East India Company "Vereenigde Oost-Indische Compagnie" — on March 20, $1602,{ }^{136}$ and the idea was further developed to allow the investors to sell

\footnotetext{
129 Hein, The University of Toronto Law Journal, supra note 27, at 144.

130 Williston, HaRvard LAW REVIEW, supra note 26, at 109-110.

131 Micklethwait \& Wooldridge, The Company: A Short History of a Revolutionary Idea, supra note 27, at 18.

132 BRAUDEL, The Perspective of the World, supra note 15, at 262. For more details about the history of the development of the limited liability idea before and after the East India Company see Hein, The University of Toronto LaW JOURNAL, supra note 27, at 147-150.

133 Gevurtz, Washington Law Review, supra note 128, at 482.

134 SмIтH, An Inquiry Into the Nature and Causes of the Wealth of Nations, supra note 112, at 997.

135 BRAUDEL, The Wheels of Commerce, supra note 45, at 450.

136 BRAUDEL, The Perspective of the World, supra note 15, at 213, 216.
} 
and trade their shares on the stock exchange. ${ }^{137}$ It is noteworthy that many other corporations were founded in the same period and had similar names, for instance the French East India Company was founded in 1664, and the West India Company was also founded in 1664. ${ }^{138}$

It seems that all the ideas developed during that same period were wrongly attributed to the East India Company, despite the fact that many other well-known joint-stock corporations, like the Muscovy Company, which was also known by some authors as the Russia Company and which was founded around 1553-1555, ${ }^{139}$ the Mines Royal in 1564, ${ }^{140}$ and the Levant Company in $1581,{ }^{141}$ were all chartered even before the East India Company, which was founded in 1599 and chartered on December 31, 1600. Despite that fact, many authors claimed that it was the "mother of our known modern corporations." 142

That might not be surprising, after the revelation of the fact that the East India Company, with all of its very long history, not only survived for more than five centuries, but is still alive today among all modern corporations in the 21 st century. ${ }^{143}$ It is noteworthy that there are other corporations that were founded almost in the same period and are also still alive, but none of which are as famous as the East India Company. One of those corporations is the Hudson's Bay Corporation, founded on May $2,1670 .^{144}$

137 Micklethwait \& Wooldridge, The Company: A Short History of a Revolutionary Idea, supra note 27, at 20.

138 BRAUDEL, The Wheels of Commerce, supra note 45, at 451.

139 Gevurtz, Washington Law Review, supra note 128, at 481; Braudel, The Wheels of Commerce, supra note 45, at 439, 449; MicklethWAIT \& WoOLDRIDGE, The Company: A Short History of a Revolutionary Idea, supra note 27, at 18.

140 BaKan, The Corporation: The Pathological Pursuit of Profit and Power, supra note 126 , at 8 .

141 BRAUDEL, The Wheels of Commerce, supra note 45, at 449.

142 Nick Robins, The Corporation that Changed the World: How the East India Company Shaped the Modern Multinational at 5 (Pluto. 2006); Gevurtz, Washington LaW RevieW, supra note 128, at 481; Smith, An Inquiry Into the Nature and Causes of the Wealth of Nations, supra note 112, at 997.

143 For more information about the current activities and news of the East India Company, see its official website: https://www.theeastindiacompany.com (last visited December 1, 2017).

144 Davis, Essays in the Earlier History of American Corporations, supra note 86, at 35; The Royal Charter For InCORPorating THE Hudson's Bay Company Granted by His Majesty King Charles the Second, in the TwentySecond Year of His Reign, A.D. 1670, at 24 (Henry Kent Custon \& Son. 1865); Micklethwait \& Wooldridge, The Company: A Short History of a Revolutionary Idea, supra note 27, at 17; and for more information about the current activities and 
The East India Company was first chartered for the purpose of practicing trade between the UK and Asia under the theme of the trading sea voyages, ${ }^{145}$ and that was developed in time to a permanent structure that ended up ruling India with an army of 260,000 troops. ${ }^{146}$ Moreover, there were great debates concerning the East India Company, for instance a slavery debate resulted in a boycott of one of its products i.e. sugar, until it started to import sugar from a non-slavery manufacturer in Bengal. ${ }^{147}$ More significantly, in a political context, granting the East India Company monopoly rights over the trade of tea in 1773 led to huge protests and 342 boxes of tea were thrown into the ocean, which directly led to the formation of the Boston Tea Party. ${ }^{148}$

Moreover, it has been claimed that the East India Company heavily contributed to the development of ideas about the modern corporation. For instance its structure could be considered a new development during these early stages of the formation of the corporation idea, whereby it was designed to be managed by two courts, the first court being a general one and consisting of all the share owners, and the second court consisting of the managing directors. In that regard it has been reported that the sons of the owners of large shares were always selected to management positions. ${ }^{149}$

It is noteworthy here that in addition to the well-known purpose of the chartered corporations during that period, which was mainly trading, ${ }^{150}$ another purpose that was considered as a "quasi-government" purpose was in time to serve certain interests of the king or the public, for instance sponsoring the searching for new sea passages, and canals excavation. ${ }^{151}$ Moreover, the UK and France chartered two corporations, the South Sea Company and the Mississippi Company, in order to rescue them from huge post-war debts by the end of the 17 th century, ${ }^{152}$ but as will

news of the Hudson's Bay Corporation, see its official website: http://www.hbc.com (last visited December 1, 2017).

145 Robins, The Corporation that Changed the World: How the East India Company Shaped the Modern Multinational, supra note 142, at 5.

146 Micklethwait \& Wooldridge, The Company: A Short History of a Revolutionary Idea, supra note 27 , at xvi.

147 Id. at 25.

148 For more details see Wesley S. Griswold, The Night the Revolution Began: The Boston Tea Party, 1773 at 93-106 (The Stephen Green Press. 1972). 149 Micklethwait \& Wooldridge, The Company: A Short History of a Revolutionary Idea, supra note 27, at 23.

150 Williston, HARVARD LAW REvIEW, supra note 26, at 109.

151 Micklethwait \& Wooldridge, The Company: A Short History of a Revolutionary Idea, supra note 27, at 40.

$152 I d$. at 28. 
be discussed in the next section, that led to the largest financial disaster in history.

Meanwhile, some other corporations were chartered in the same period to serve the king's interest, and surprisingly most of them contributed heavily to the development and prosperity of the American Colonies, such as the Virginia Company and the Massachusetts Bay Company. ${ }^{153}$ It is noteworthy that in time those corporations obtained their independence from the UK, through a series of soft transition steps, and the final step to obtain such independence was taken by a remarkable decision declared by the Supreme Court in the case of Trustees of Dartmouth College $v$. Woodward in $1819 .{ }^{154}$

\section{(b) South Sea Company and the Bubble Act ${ }^{155}$}

The South Sea Company was chartered in 1711 as one of the joint-stock corporations that were founded during that period. Its main purpose was trading and it was granted exclusive rights to trade with "Spanish America." After struggling in its trade activities, by 1719 its manager John Blunt decided to change the purpose to be mainly lending money to the British government. ${ }^{156}$ During the same period, the typical feature among all the joint-stock corporations that offered their shares to trade was that there were great fluctuations in the prices in the market, and many of those corporations collapsed, and remarkably that trend reached its peak by 1720.157

In 1720 the British Parliament devoted all its efforts to rescuing the South Sea Company from collapsing. To be more precise, Parliament helped the corporation to put a plan for its purpose into effect, and at the same time helped it to flourish by trading its debt shares. ${ }^{158}$ Parliament did this in two steps, the first was on January 21, 1720, when it announced that the South Sea Company would handle the British government debt exclusively, and that led to instant outrageous increases in the prices of

\footnotetext{
153 DAVIs, Essays in the Earlier History of American Corporations, supra note 86 , at 34 .

154 Trustees of Dartmouth College v. Woodward, 17 U.S. (4 Wheat.) 518 (1819).

155 Bubble Act 1720 (6 Geo I, c 18).

156 Micklethwait \& Wooldridge, The Company: A Short History of a Revolutionary Idea, supra note 27, at 31.

157 Pettet, Company Law, supra note 125, at 9.

158 Arner, SOUthern Methodist University Law Review, supra note 27, at 33.
} 
the shares of the South Sea Company from $£ 128$ in January to $£ 187$ in February and finally $£ 950$ on June $24 .{ }^{159}$

Unfortunately, the South Sea Company was about to collapse and the instant outrageous increase of the shares prices formed an actual "Bubble," as it was named by most scholars. That bubble had burst by September in the same year, and suddenly the owners of the shares found nothing that resembled their shares value. ${ }^{160}$ Other authors named it " $[\mathrm{t}] \mathrm{he}$ drama of the South Sea Company," as it was the biggest financial crisis in that early history. ${ }^{161}$

The second step was the Bubble Act, which was enacted by the British Parliament in the same year, on June 11, 1720. That Act was designed mainly to decrease the number of joint-stock corporations that might compete with the South Sea Company; according to that Act the Parliament prohibited any unchartered joint-stock corporation, thus resulting in any joint-stock corporation being permitted to be chartered only by Act of Parliament. ${ }^{162}$ That second step succeeded in giving a hand to prevent the collapse of the South Sea Company, and the corporation survived the crisis and even the price of its shares returned to $£ 170$ again by October in the same year, followed by the British government nationalizing the corporation for its own interest i.e. to avoid paying the government debt. ${ }^{163}$

The inevitable result of the Bubble Act in the UK was that investors rerouted their trading practices, to be done through old tools such as partnerships, and since the old tools were not equipped with the limited liability feature, the economy faced a great delay. ${ }^{164}$ It was even reported that most of the merchants, during that period, advanced the partnerships agreement to imitate the joint-stock corporations by making the shares of the partnership tradable. ${ }^{165}$

159 Micklethwait \& Wooldridge, The Company: A Short History of a Revolutionary Idea, supra note 27, at 31-32; Arner, Southern Methodist UNIVERSITY LAW REVIEW, supra note 27, at 33.

160 Pettet, Company Law, supra note 125, at 9; Arner, Southern Methodist UNIVERSITY LAW REVIEW, supra note 27, at 33.

161 Micklethwait \& Wooldridge, The Company: A Short History of a Revolutionary Idea, supra note 27, at 31.

162 Arner, Southern Methodist University LAw Review, supra note 27, at 33; Micklethwait \& Wooldridge, The Company: A Short History of a Revolutionary Idea, supra note 27, at 32.

163 Micklethwait \& Wooldridge, The Company: A Short History of a Revolutionary Idea, supra note 27, at 33.

164 Arner, Southern Methodist University Law ReVIEW, supra note 27, at 33.

165 Micklethwait \& Wooldridge, The Company: A Short History of a Revolutionary Idea, supra note 27, at 40. 
The influence of the Bubble Act was not limited to the UK, it was also expanded to the American Colonies in 1741, and obviously that also delayed growth in the economy for some time. ${ }^{166}$ However, the effect in the American Colonies was intolerable, because the economy mainly depended for its existence and proliferation on the early corporations. For instance, all of the important American institutions were chartered as a corporation: banks, canals, churches, roads, and even universities; Harvard University was chartered as a corporation in $1636 .{ }^{167}$

Some authors claimed that the American Colonies did not get rid of the Bubble Act until the Declaration of Independence on July 4, 1776, ${ }^{168}$ however the Pennsylvania Assembly i.e. the parliament, violated the British prohibition and granted a corporation named the Philadelphia Contributionship ${ }^{169}$ a charter as an American insurance corporation in 1768 , prior to the Declaration of Independence. It was also reported that the first American corporation, the Bank of North America, was founded in 1781 in the north of the US after that British prohibition. ${ }^{170}$ It is undoubtedly true that the US boomed after getting rid of the Bubble Act, while the UK economy was still suffering from its effect, and it was even reported that 350 corporations were incorporated in the US during the period between 1783 and 1801, while no comparable activity was reported in the UK in the same period. ${ }^{171}$

The Bubble Act was not repealed in the UK until 1825, more than a century after its application; by that time there was an urgent economic need to allow individuals to do more business in order to rescue the economy. ${ }^{172}$ In 1844 the British Parliament enacted a new Act to allow individuals to incorporate new joint-stock corporations as easily as by mere

166 Arner, Southern Methodist University Law Review, supra note 27, at 43.

167 Micklethwait \& Wooldridge, The Company: A Short History of a Revolutionary Idea, supra note 27, at 43.

168 Arner, Southern Methodist University Law Review, supra note 27, at 44.

169 The Philadelphia Contributionship corporation is still alive; for more information about its history and current activity see its official website http:// www.contributionship.com or https://1752.com (last visited December 1, 2107).

170 Micklethwait \& Wooldridge, The Company: A Short History of a Revolutionary Idea, supra note 27, at 44.

171 Oscar Handlin \& Mary F. Handlin, Origins of the American Business Corporation, 5 The Journal of Economic History 1, at 4 (1945).

172 Pettet, Company Law, supra note 125, at 9. Hein, The University of Toronto Law JournaL, supra note 27, at 138-139. 
registration. ${ }^{173}$ However, the repeal of the Bubble Act did not have the expected effect. It was also reported that even after its repeal the situation was unreliable, because the incorporation of the joint-stock corporations was by that time a matter of the common law and the principles of the common law were neither developed nor solid enough to be relied upon. ${ }^{174}$

Accordingly, the Joint Stock Companies Act was enacted to fully recognize the unchartered joint-stock corporations. ${ }^{175}$ It is noteworthy that the British government was very hesitant toward the unchartered corporations in the period after the repeal of the Bubble Act, and it started to recognize joint-stock banks as incorporated corporations by registration in 1826. It then changed the rules and one was not allowed to incorporate such a corporation unless it was by a "letter of patent" in 1844, then it was changed again so that it was permissible again to incorporate it as easily as by registration in $1857 .{ }^{176}$

\section{(c) Trusts and antitrust law}

As will be scrutinized later along with the discussions of the relation between the state and corporations, it was widely accepted to grant most of the corporations an exclusive right to trade or to practice certain professions during the early period. However, those exclusive rights led to the development of what were called "antisocial" monopoly practices, which were widely justified on the grounds that the monopoly owner always owned scarce goods or services and should raise the prices to meet the unlimited demand for such goods or services. This appears to be untrue and even vice versa, i.e. the supply is literally unlimited while the demand is limited. ${ }^{177}$

Despite the fact that 21 states in the US had their own antitrust laws by $1890,{ }^{178}$ the US Sherman Act of $1890^{179}$ was considered the father of the modern antitrust laws, or in the words of one antitrust scholar the "Magna Carta of free enterprise." 180 Others also claimed that the Canadian Act,

\footnotetext{
173 Pettet, Company Law, supra note 125, at 9.

174 Hein, The University of Toronto LAW Journal, supra note 27, at 145.

175 Joint Stock Companies Act 1844 (7 \& 8 Vict. c.110).

176 Hein, The University of Toronto Law Journal, supra note 27, at 145-146.

177 Peter F. Drucker, Concept of the Corporation at 216, 219 (New American Library ed. 1983).

178 John H. Shenefield \& Irwin M. STElzer, The Antitrust Laws: A Primer at 108 (4th ed., AEI Press. 2001).

179 Sherman Antitrust Act, Ch. 647, 26 Stat. 209, codified at 15 U.S.C. $\S \S 1-7$.

180 Thomas James DiLorenzo, The Origins of Antitrust: An Interest Group Perspective, 5 International Review of Law and Economics 73, at 74 (1985),
} 
which was enacted on May 2, 1889, and was named "An Act for the Prevention and Suppression of Combinations Formed in Restraint of Trade," was the first modern antitrust law. ${ }^{181}$ Moreover, it has been reported that France enacted the Le Chapelier Act of $1791^{182}$ to prohibit monopolies and any trade-restraining practices. ${ }^{183}$ Even Austria enacted the Austrian Penal Code in 1852, adopting rules in the same direction, while on the other hand it has been reported that these practices were considered lawful and acceptable under other legal systems in, for instance, the UK and Germany. ${ }^{184}$

Meanwhile, digging deeper to explore the roots and the earlier seeds of the antitrust idea shows that it has more depth than those modern experiences, and it was even held that the idea was developed first by the Romans, who incorporated the idea into many of their laws. It was then further developed 500 years later in the Constitution of Emperor Zeno the Ishaurian of 483 AD. ${ }^{185}$ Even during the early period of Islam, it was recorded after Prophet Muhammad, peace be upon him, that whoever intervened in the prices to increase them, should expect the Almighty God to seat him in the worst place in hell, in addition to many other instructions that forbade monopolistic behaviors that led to an increase in prices. ${ }^{186}$

In the same context, it was also reported that later during the period of the Saxon kings, it was prohibited and considered a crime to intervene in the direct sale of goods to make a profit as a middle man. That crime was mentioned in the Domesday Book ${ }^{187}$ in 1086, and monopoly practices were also considered illegal in Magna Carta in 1215. ${ }^{188}$ That early history of antitrust was not just a few instances or laws that were adopted during

citing Marshall C. Howard, Antitrust and Trade Regulation: Selected Issues AND CASE STUdies at 1 (Prentice-Hall. 1983).

181 Anestis S. Papadopoulos, The International Dimension of EU Competition Law and Policy at 9-10 (Cambridge University Press. 2010).

182 Le Chapelier Act of June 14-17, 1791.

183 Francis Walker, The Law Concerning Monopolistic Combinations in Continental Europe, 20 Political Science Quarterly 13, at 27 (1905).

184 PAPADOPOULOS, The International Dimension of EU Competition Law and Policy, supra note 181, at 8-9.

185 Sandra Marco Colino, Competition Law of the EU and UK at 2-3 (Oxford University Press. 2011).

186 For more details about this quote and other quotes of Prophet Muhammad, peace be upon him, see NASIRUdDin Al-Khattab, ENGLish translation of Musnad Imam Ahmad bin Hanbal (Darussalam. 2012).

187 For more details about the Domesday Book see www.domesdaybook. co.uk (last visited December 1, 2017).

188 Colino, Competition Law of the EU and UK, supra note 185, at 3. 
these early periods, but the common law as a judiciary work is clear evidence that the idea was recognized in some of the early rulings, ${ }^{189}$ for example the ruling of the English courts in Dyer's case in 1414, ${ }^{190}$ and in the case of Darcy v. Allien in $1599,{ }^{191}$ and then in the case of Mitchel v. Reynolds in $1711 .{ }^{192}$ In the same context, it was even claimed that the Sherman Act of 1890 had a "transatlantic origin" and was a codifying of the old common law rules. ${ }^{193}$

As was said previously, the situation in Germany during the 16th century was similar to the UK and the US, i.e. the monopoly practices were widely accepted. For instance, giant corporations like Fuggers, Hochstetters, and Welsers were controlling mercury, silver, and copper during the 16th century and no other corporation could even plan to enter into the markets of such industries. ${ }^{194}$ However, by the end of the 16 th century, namely during the period of King James VI and I, the situation started to take a new direction in the UK. Both Parliament and the judiciary considered the granting of royal monopoly rights as unconstitutional, and that was also expanded later to the US. ${ }^{195}$ On the other hand the situation remained the same i.e. monopoly practices were accepted in Germany for many centuries and even after the beginning of the 20th century. ${ }^{196}$

Additionally, it should be noted that the aforementioned change in the UK and the US did not mean that monopoly was prohibited, it was merely unconstitutional to grant corporations such rights by the state. Indeed, to the contrary, monopoly practices were considered the main cause of the growth of some American corporations domestically, and even gaining a controlling position in the foreign markets, and by the end of the 19th century many of what were called "trusts" were formed. ${ }^{197}$ Unsurprisingly, what mainly triggered the debate in the US concerning the prohibition of

189 DABBAH, The Internationalisation of Antitrust Policy, supra note 9, at 32. Papadopoulos, The International Dimension of EU Competition Law and Policy, supra note 181, at 7-9.

190 Dyer's case, (1414) 2 Hen. V, fol. 5, pl. 26.

191 Edward Darcy Esquire v. Thomas Allin of London Haberdasher (1599) 74

ER 1131, (1602) 77 Eng. Rep. 1260 and (1599) Noy 173.

192 Mitchel v. Reynolds (1711), 1 P. Wms., 181, 24 Eng. Rep. 347.

193 DABBAH, The Internationalisation of Antitrust Policy, supra note 9, at 32.

194 BRAUDEL, The Wheels of Commerce, supra note 45, at 418.

195 Shenefield \& Stelzer, The Antitrust Laws: A Primer, supra note 178, at

$8-9$.

196 Micklethwait \& Wooldridge, The Company: A Short History of a Revolutionary Idea, supra note 27, at 90-91.

197 Shenefield \& Stelzer, The Antitrust Laws: A Primer, supra note 178, at 9. 
monopoly practices or even the abuse of the granted monopoly powers was the growth and expansion of these trusts. ${ }^{198}$

An overview on the history of the Standard Oil Corporation may give a clearer picture of how these trusts appeared and grew in the US and then developed into the main trigger of the mentioned debate, and even then led to what was named antitrust laws. ${ }^{199}$ The story begins in 1852, when John Davison Rockefeller and his friend Maurice Clark started to "pool" some of their savings and to use them in "commission business," and by 1862 they partnered with Samuel Andrews to start a new promising business, an oil refinery. Henceforth their business grew and they started a second refinery and then they opened branches in different states. Rockefeller then invested in many refinery businesses, and by June 1870 he merged all his businesses, which were worth more than 1 million US dollars, under the umbrella of the Standard Oil Corporation. ${ }^{200}$

A dramatic change happened in 1871, when Rockefeller met a businessman who had a magic tool that was offered for sale; that magic tool was a corporation chartered under the name of the "South Improvement Company," and the owner of that charter was granted the ability to do any business of any nature in whatever place he might decide. There is no need to mention that Rockefeller took the opportunity and bought the charter, but he was not alone, he arranged for a new form of institution or association, and on January 2, 1872 he and many other businessmen in the refinery business pooled and divided the 2,000 shares of that corporation between themselves, and formed an association or new business structure that was then known as a "trust" to take over the oil industry. ${ }^{201}$ That oil trust, or to be more precise the trust idea, was copied by many other businessmen, in many other industries in the US, during the same period, most notably the industries of sugar refining, tobacco, railroads, and steel among others. ${ }^{202}$

198 Andreas Koutsoudakis, Antitrust More than a Century After Sherman: Why Protecting Competitors Promotes Competition More than Economically Efficient Mergers, 34 Dayton Law Review 223, at 230 (2009); Rudolph J. R. Pertiz, Competition Policy in America, 1888-1992: History, Rhetoric, LaW at 9 (Oxford University Press. 1996).

199 For the full history of the Standard Oil Corporation, see IDA M. TARBELL, The History of the Standard Oil Company $\S 1$ (Mc Clure, Phillips \& Co. 2nd Impression ed. 1904). It is noteworthy that the author vividly mentioned that she was a daughter of one of the many oil producers who was heavily harmed by the oil trusts.

$200 \quad I d$. at $42-44$.

201 Id. at 56-57.

202 Papadopoulos, The International Dimension of EU Competition Law and Policy, supra note 181, at 10; Pertiz, Competition Policy in America, 1888-1992: 
Controlling an industry was not a new trend that was sufficient to develop the antitrust idea, it just triggered the debate in that regard, and thus the debate led to the development of the antitrust laws in the US. The following discussion will be an overview on the history of such debate. It is noteworthy here that while the history may reveal some of the legislative intent or goals, the discussion of such goals will come later during the discussion of merger control as an impediment. ${ }^{203}$

It should be noted that the debate lasted for almost two years, starting from January 21, 1888 until the enactment of the Sherman Act in 1890. ${ }^{204}$ To be more precise, it was started by the Representative of New York State, Henry Bacon, when he requested the inspection of the trusts, and unsurprisingly, the Senator of the State of Ohio, which was the state that chartered the Standard Oil Corporation; Senator John Sherman presented an antitrust Bill by the middle of August 1888, and that Bill was even named after him i.e. the "Sherman Act."205

One might think that Senator Sherman presented that Bill because the trusts were controlling the markets during that period, and that control led

History, Rhetoric, Law, supra note 198, at 13; and see generally DiLorenzo, INTERNATIONAL REVIEW OF LAW AND ECONOMICS, supra note 180.

203 An enormous amount of literature could be cited for more information and details about the history and the circumstances that led to the enactment of the Sherman Act, for example: Pertiz, Competition Policy in America, 1888-1992: History, Rhetoric, Law, supra note 198, at 9, citing over 50 references, most importantly Hans Birger Thorelli, The Federal Antitrust Policy: Origination of an American Tradition (Johns Hopkins Press. 1955); William L. Letwin, Congress and the Sherman Antitrust Law: 1887-1890, 23 THE UNIVERSITY of Chicago Law Review 221 (1956); Richard Hofstadter, What Happened to the Antitrust Movement?, in The Paranoid Style in American Politics, and Other Essays (1965); Rudolph J. R. Pertiz, Rule of Reason in Antitrust Law: Property Logic in Restraint of Competition, 40 Hastings Law Journal 285 (1989); David Millon, The Sherman Act and the Balance of Power, 61 Southern CaLIFornia LAw Review 1219 (1988); Robert H. Lande, Wealth Transfers as the Original and Primary Concern of Antitrust: The Efficiency Interpretation Challenged, 34 Hastings Law Journal 65 (1982); John J. Flynn, Rethinking Sherman Act Section 1 Analysis: Three Proposals for Reducing the Chaos, 49 Antitrust Law Journal 1593 (1980); Eleanor M. Fox, The Modernization of Antitrust: A New Equilibrium, 66 Cornell Law Review 1140 (1981); Colino, Competition Law of the EU and UK, supra note 185, at 3, citing Hans Birger Thorelli, The Federal Antitrust Policy: Origination of an American Tradition (Johns Hopkins Press. 1955); see also Richard Orme Wilberforce, The LaW of Restrictive Trade Pratices AND Monopolies (2nd ed., Sweet \& Maxwell. 1975).

204 Pertiz, Competition Policy in America, 1888-1992: History, Rhetoric, Law, supra note 198, at 13.

205 Id. at 9. 


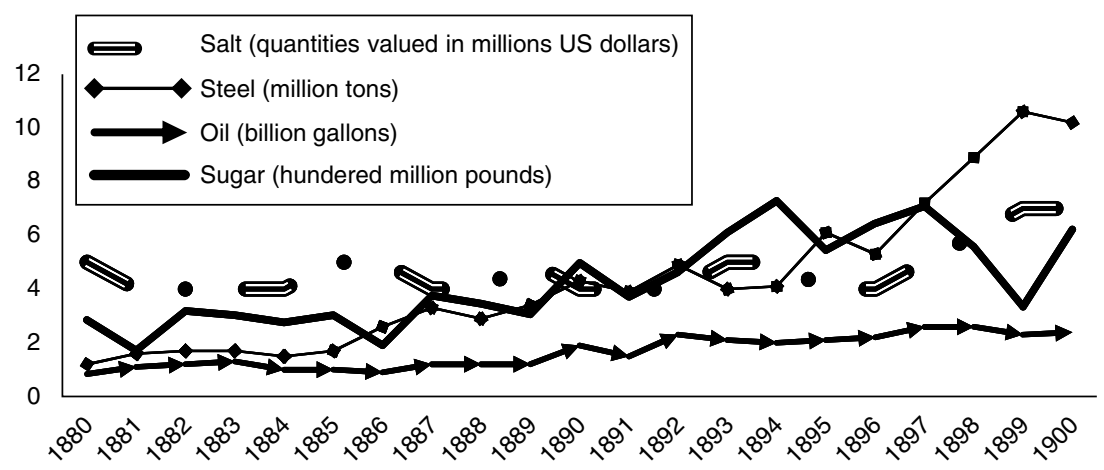

Source: Data retrieved from Thomas James DiLorenzo, The Origins of Antitrust: An Interest Group Perspective, 5 InTERNATIONAL REVIEW OF LAW AND ECONOMICs 73, 78-79 (1985), citing US Bureau of the Census, Statistical Abstract of the U.S., various years (Washington D.C.: Government Printing Office); US Bureau of the Census, Historical Statistics of the U.S.

\section{Figure 1.1 Output of certain industries during the period 1880-1900}

to public anger due to high prices, or due to the shortage of supply, or even the bad quality of goods or services, but surprisingly by scrutinizing the congressional records and analyzing some of the speeches of the senators on that debate extremely unexpected results were revealed. Senator George Franklin Edmunds said: "Although for the time being the sugar trust has perhaps reduced the price of sugar, and the oil trust certainly has reduced the price of oil immensely, that does not alter the wrong of the principle of any trust." 206

It is noteworthy here that a deep analysis of the available data showed that the trusts actually added to the output of the economy, during the period from 1880 to 1900 , and there was an actual growth of output, and that was not limited to certain trusts but literally for all the trusts, for example oil, salt, steel, and sugar, as appears in Figure 1.1. ${ }^{207}$

Moreover, that opinion was not just a single opinion, it was the opinion of most of the House at that time, and for example one of the most important statements was the statement by Senator William Ernest Mason, where he clearly said that

206 Congressional Record, 51st Congress, 1st Session, House, 20 June (1890) P.2558.

207 DiLorenzo, InTERnational Review of LAW AND Economics, supra note 180 , at 77-78. 
trusts have made products cheaper, have reduced prices; but if the price of oil, for instance, were reduced to one cent a barrel, it would not right the wrong done to the people of this country by the "trusts" which have destroyed legitimate competition and driven honest men from legitimate business enterprises. ${ }^{208}$

It is very clear that they were arguing about the protection of small businesses from the trusts, a giant powerful business that might swallow them easily, but unfortunately the prices were not important, which meant that the antitrust was at the cost of consumers. In that context it has been claimed that the purpose was to save the "less efficient 'honest men' [from being driven] out of business." 209

To elaborate more on that point, while the senators revealed vividly that the oil and sugar trusts kept the trend of the prices going down, some authors argued that there was also another cause, which was the drop of the railroad prices. ${ }^{210}$ Actually, it could be easily recognized that both of these causes i.e. the trusts and the drop of the railroad prices, were interrelated, because the trusts were using the railroads as a means of transportation and they managed to get rebates for their large transactions, ${ }^{211}$ and that led to the drop of the railroads prices and vice versa; the drop of the transportation prices led to the fall in the prices of goods.

Accordingly, the overall trend of the prices was going down for the good of consumers, but at the same time other groups of people were unhappy with these results. Those groups were mainly the small businesses owners and the farmers, and they simply could not manage to get the same transportation prices for their small transactions and thus they struggled to compete with the prices offered by the trusts or generally speaking with the price trend during that period. Those groups joined the debate on the side of the pro-antitrust camp, ${ }^{212}$ even if they were not considered as the actual triggering factor of the antitrust debate.

However, the first Bill that was presented by Senator Sherman was very

\footnotetext{
208 Congressional Record, 51st Congress, 1st Session, House, 20 June (1890) P.4100.

209 DiLorenzo, InTERnational Review of LAW AND Economics, supra note 180, at 87; Koutsoudakis, DAYTON LAW REVIEW, supra note 198, at 245.

210 Douglass North, Growth and Welfare in the American Past: A New ECONOMIC History at 139 (Prentice Hall. 1966).

211 DiLorenzo, InTERnational Review of LAW AND ECONOMics, supra note 180 , at $75-76$.

212 Sanford D. Gordon, Attitudes towards Trusts prior to the Sherman Act, 30 SOUTHERn ECONOMIC Journal 156, at 158 (1963).
} 
confusing as actually its language indicated that the goal was nothing other than to protect consumers as follows: "That all arrangements, contracts, agreements, trusts, or combinations . . made with a view, or which tend to prevent full and free competition ... or which tend to advance the cost to the consumer ... are hereby declared to be against public policy, unlawful, and void." 213 Here it was clearly declared that the debate was taking into consideration mainly the protection of the consumer, side by side with the goal of "full and free" competition as a means to protect the consumer, but not as an end in itself.

When the debate over that Bill started on January 23, 1889, ${ }^{214}$ Senator Sherman himself declared the same meaning; he actually denied that the purpose of his Bill was

to cripple combinations of capital and labor, the formation of partnerships or of corporations, but only to prevent and control the combinations made with a view to prevent competition, or for the restraint of trade, or to increase the profits of the producer at the cost of the consumer. It is the unlawful combination ... not the useful combination. ${ }^{215}$

It is also clear that Senator Sherman was trying to defend the language of his Bill by any means; some of his reasoning does not even make sense: He said that his Bill sought to make the "unlawful combination" unlawful. Meanwhile, it seems that most of the voices in the House were standing for purposes other than that declared by Senator Sherman; the Bill was referred to another committee and it was returned after six days with different language saying nothing about the "cost to the consumer" or even "full and free competition." The Bill passed with new language dealing with "restraint of trade," and by a majority of 52 to one. ${ }^{216}$

The enactment of the Sherman Act did not put an end to the debate.

213 H.R. Misc. Doc. No. 124, 50th Cong., 1st Sess., 19 CONG. REC. 719 (1888) (in substitution of H.R. REP. No. 67, introduced by Representative William Mason (R.I11). The resolution directed the House Judiciary Committee to investigate certain charges about trusts' high prices to consumers. REPORT OF THE HOUSE COMMITTEE ON MANUFACTURES, H.R. REP. No. 3112, 50th Cong., 1st Sess. (July 30, 1888); S. 3440 and S. 3445, 50th Cong., 1st Sess., 19 CONG. REC. 7512 (1888); S. 3445, 50th CONG. REC. 1120 (1889) (as amended). Earl W. Kintner, The Legislative History of the Federal Antitrust Laws and Related Statutes at $53 \S 1$ (Chelsea House Publishers. 1978).

214 Pertiz, Competition Policy in America, 1888-1992: History, Rhetoric, Law, supra note 198, at 13.

215 Cong Rec S.1, 51st Cong 1st Sess. (March 18, 1890) P.2457.

216 Pertiz, Competition Policy in America, 1888-1992: History, Rhetoric, Law, supra note 198, at 13-14. 
Instead, the debate spread to the courts and it was more confusing when enforced. It was also claimed that the continuous debate was anticipated and that it distracted the public's attention from the introduction of a new trade restraint tool, which was a new tariff Bill sponsored by Senator Sherman himself. $^{217}$ There was too much evidence supporting that claim, for instance the first time the Sherman Act was used against the oil trusts i.e. the Standard Oil Corporation, was more than 15 years after the law was enacted in $1906 .^{218}$

Actually, it was not the first time that a lawsuit had been initiated against the oil trusts represented by the Standard Oil Corporation; in 1889 David Watson, the Attorney General of the state of Ohio, accidentally read the agreement of the trust of the Standard Oil Corporation, and he realized that it violated the Ohio Charter by controlling other corporations out of the state of Ohio. The Supreme Court of Ohio decided on the side of the state, but it did not declare the charter as void, and the trust continued under a new name, the "liquidating trustees." 219 Accordingly Rockefeller moved the corporation to the more liberal State of New Jersey, and that actually led to the expansion of his business even more freely.

By 1899 the oil trust was the owner and controlled another 40 corporations, ${ }^{220}$ and it was even reported that the expansion was a result of the increase of its capital from 70 million to more than 100 million US dollars. ${ }^{221}$ The second lawsuit against the oil trust, which was the first under the Sherman Act, was a knockdown of the trust: in 1911 the Supreme Court ordered the divestiture of some of the assets of the 22 billion US dollars trust, and the result was giant oil corporations, namely Amoco, Chevron, Exxon, and Mobil. ${ }^{222}$

Finally it should be noted that the movement on the west side of the Atlantic never stopped and many amendments were introduced to the Sherman Act. These amendments will be discussed later along with the discussions of merger control. ${ }^{223}$ Furthermore, that movement was met with

217 DiLorenzo, International Review of LAW AND Economics, supra note 180 , at 87 .

218 Micklethwait \& Wooldridge, The Company: A Short History of a Revolutionary Idea, supra note 27, at 73.

219 Ida M. Tarbell, The History of the Standard Oil Company at 150, 153 $\S 2$ (McClure, Phillips \& Co. 2nd Impression ed. 1904).

220 Micklethwait \& Wooldridge, The Company: A Short History of a Revolutionary Idea, supra note 27, at 68.

221 TARBELL, The History of the Standard Oil Company, supra note 219, at 153.

222 Micklethwait \& Wooldridge, The Company: A Short History of a Revolutionary Idea, supra note 27, at 73.

223 See infra p.193. 
deep silence on the other side of the Atlantic, i.e. the European countries did not take their actual first steps toward modern antitrust regulation until it was incorporated in the Treaty establishing the European Coal and Steel Community (hereinafter ECSC) on April 18, 1951.224

However, it has been claimed that the first European step was on March 25, 1957, indeed when the Treaty Establishing the European Economic Community (hereinafter EEC) was signed. ${ }^{225}$ From that time on antitrust was considered "a fundamental provision which is essential for the accomplishment of the tasks entrusted to the [EU] and, in particular, for the functioning of the internal market."226

\section{(d) Merger waves}

Mergers as an idea was not clearly known during the Middle Ages. Even the idea that one corporation can own or create another one was disputable, as was previously shown in the discussions concerning the early characteristics of corporations. Whereas some claimed that corporations were not allowed to do so, ${ }^{227}$ others maintained it was permissible, ${ }^{228}$ and some even mentioned an example to support that last claim, which was that the king at these periods was a corporation himself and he was allowed to own and create other corporations; in the same context many American Colonies were corporations and they created corporations. ${ }^{229}$

Accordingly, and since mergers were very limited, if not totally forbidden, the resources discussing their history during these early stages are very scarce; only a handful of early merger examples were reported. For instance, the first report of a merger was that of the Dutch East India Company (Vereenigde Oost-Indische Compagnie), which was formed on March 20, 1602, and which was a merger between several corporations. ${ }^{230}$ It was also reported that in 1702 the Queen and two corporations entered

224 Colino, Competition Law of the EU and UK, supra note 185, at 5.

225 PAPAdOPOUlOS, The International Dimension of EU Competition Law and Policy, supra note 181, at 14; The EEC was renamed after the Treaty of Maastricht of 1992 to the Treaty Establishing the European Community (hereinafter TEC), and it was renamed again after the treaty of Lisbon of 2007 to the Treaty on the Functioning of the European Union (hereinafter TFEU).

226 Eco Swiss China Time Ltd v. Benetton International NV, Case C-126/97 [2000] 5 CMLR 816, para. 36.

227 ShePpARD, Of Corporations, Fraternities, and Guilds, supra note 96, at 112.

228 Grant, A Practical Treatise on the Law of Corporations in General: As

Well Aggregate as Sole, supra note 95, at 9-10.

229 Eaton, The Yale Law Journal, supra note 19, at 370-371.

230 BRAUDEL, The Perspective of the World, supra note 15, at 213. 
into some sort of agreement named "indenture tripartite" in order to unite, and then that turned into a completely merged corporation by an Act of the British Parliament in 1708, with the outcome, i.e. the new corporation, being named "The United Company of Merchants trading to the East Indies." That was the case until the second half of the 19th century. ${ }^{231}$

Starting from the second half of the 19th century, mergers started to be a reality of economic life, and it has been claimed that the trusts that were formed at that time could be considered typical mergers. That was obvious in the case of the oil trust of the Standard Oil Corporation, and one more example was the tobacco trust: in 1890 James Buchanan Duke, who owned a tobacco corporation, had it merge with four other corporations to form the American Tobacco Company, and the same trend also appears in many other industries like cotton and steel. ${ }^{232}$

In Germany, during the same period, the recession was a great driving force to unite, but rather than enter into mergers they preferred a softer tool to unite, and most of the corporations entered into "cartels." It was even reported that four cartels were formed by 1875 and that number increased to 385 by $1905 .{ }^{233}$ Preferring that form of uniting, rather than merging, may be attributed to the fact that these cartels resembled trade restraint practices, which were permitted and even widely accepted in Germany during that same period, as was previously noted.

Examining the literature concerning the history of mergers, which is very scarce, reveals that the only comprehensive data that were recorded was limited to US transactions, thus the following discussion of merger waves in history will be limited to the merger history only in the US. Furthermore, examining the literature reveals also that the available resources have many limitations; for instance some are limited to specific industries like the mining industry, while others are limited to transactions with certain values, and even other limitation factors such as specific periods.

Meanwhile, most of the literature that was written about merger history was mainly dependent on the same resources, and again that was due to the scarcity of the recorded data concerning the early mergers.

231 Smith, An Inquiry Into the Nature and Causes of the Wealth of Nations, supra note 112, at 999.

232 Micklethwait \& Wooldridge, The Company: A Short History of a Revolutionary Idea, supra note 27, at 65-68.

233 Alfred Chandler \& Takashi D. Hikino, Scale and Scope: The Dynamics of Industrial Capitalism at 423 (Belknap Press. 1990). 
These resources are mainly (1) the work done at the National Bureau of Economic Research, most notably by Ralph Nelson, ${ }^{234}$ (2) the publications of the US Federal Trade Commission (hereinafter FTC), (3) the periodical named Mergers and Acquisitions, and (4) the annual reports of W. T. Grimm \& Co. ${ }^{235}$

It is noteworthy that most of the literature regarding merger history agrees on the fact that mergers throughout history were always characterized by taking the form of waves or movements and some named it "episodic." 236 The wave begins at a certain time and then booms until it reaches its peak and then slows down again, usually because of a reces$\operatorname{sion}^{237}$ or financial crisis. ${ }^{238}$ The reason behind the fact that mergers were episodic or in the form of waves will be identified in the coming discussion as each of those waves has its own circumstances.

In addition to that, the literature broadly agrees on the periods that constitute mergers waves, and obviously on the number of those waves, which are six from the end of the 19th century to date, as will be shown in this discussion. It should be noted here that the following discussion will mainly focus on the first five waves. Furthermore, the last two waves are literally contemporary waves and they share the same general trends and characteristics, as will be discussed later.

However, most of the literature disagrees concerning the exact time at which the first wave started: Some contended that it started in 1893, while others claimed it started in 1895; others maintained it started in 1897, and even others claimed it started in $1898 .{ }^{239}$ In fact, the starting date of the first wave was not the only disagreement, but the dates of the starting and

234 Ralph L. Nelson, Merger Movements in American Industry, 18951956 at vii-viii (Princeton University Press. 1959).

235 For more details about these resources and any industry, time, and transaction value limitation therein, see Alan J. Auerbach, Mergers and Acquisitions at 26-29 (University of Chicago Press paperback ed. 1988).

236 Nelson, Merger Movements in American Industry, 1895-1956, supra note 234, at 4 .

237 Patrick A. Gaughan, Mergers, Acquisitions, and Corporate RestruCtURINGS at 50-51 (3rd ed., Wiley. 2002).

238 Donald M. DePamphilis, Mergers and Acquisitions Basics: All You NeEd to KNOW at 24-25 (Academic Press. 2011).

239 J. Fred Weston \& Samuel C. Weaver, Mergers and Acquisitions at 7 (McGraw-Hill. 2001); Brett Cole, M\&A Titans: The Pioneers Who Shaped Wall Street's Mergers and Acquisitions Industry at 2 (John Wiley \& Sons. 2008); Nelson, Merger Movements in American Industry, 1895-1956, supra note 234, at 4; Gaughan, Mergers, Acquisitions, and Corporate Restructurings, supra note 237, at 23, 27; DePAmpHILIs, Mergers and Acquisitions Basics: All You Need to Know, supra note 238, at 24. 


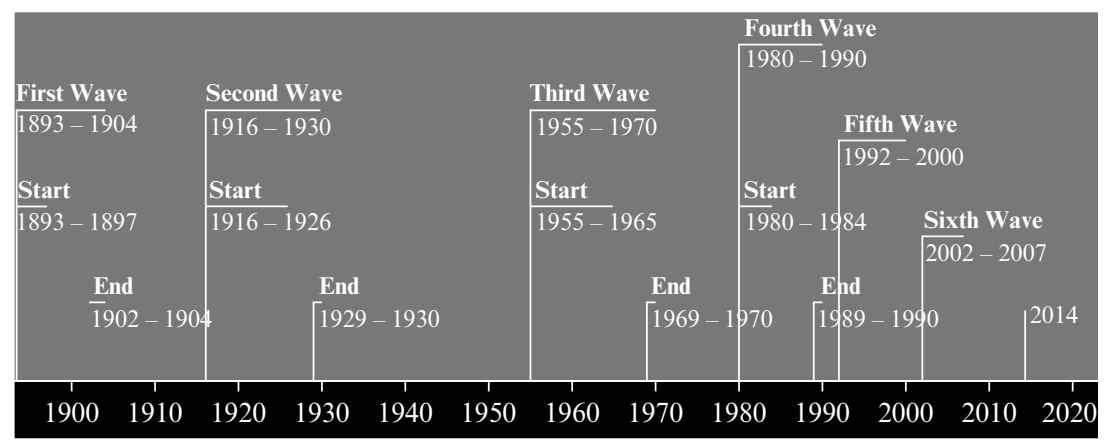

Source: Data retrieved from J. Fred Weston \& Samuel C. Weaver, Mergers and ACquisitions at 7-8 (McGraw-Hill. 2001); Joseph StanclifFe Davis, Essays IN the EARLIER History OF AMERICAN CORPORATIONS at 2 (Harvard University Press. 1917); Patrick A. Gaughan, Mergers, Acquisitions, and Corporate Restructurings at 23, 28, 30, 32, 44, 50, 51 (3rd ed., Wiley. 2002); Brett Cole, M\&A Titans: The Pioneers Who Shaped Wall Street's Mergers and Acquisitions Industry at 2 (John Wiley \& Sons. 2008); Donald M. DePamphilis, Mergers and Acquisitions Basics: All You Need to Know at 24, 25, 27, 29 (Academic Press. 2011); Oliver Black, Conceptual Foundations of Antitrust at 23-24 (Cambridge University Press. 2005); RalPh L. Nelson, Merger Movements in AMERICAN INdustry, 1895-1956 at 5 (Princeton University Press. 1959); Larry D. Qiu \& Wen Zhou, Merger Waves: A Model of Endogenous Mergers, 38 THE RAND JOURNAL OF ECONOMICS 214, at 214 (2007).

\section{Figure 1.2 Timeline of merger waves}

the ending of all the waves are debatable, and that might be due to the lack of data; as was previously noted this might be due to different data analysis or interpretation.

Nevertheless, the differences are not crucial and will not lead to wrong results, at least in the context of this book, especially because all the claimed dates fluctuate within a small range, as illustrated in Figure 1.2. But it should be noted that it has been argued by one author that there was a merger wave during the period from 1946 until 1956, and he even maintained that it was the third wave. ${ }^{240}$ Meanwhile no one held the same view, and therefore that wave will be set aside and not be included in the timeline and the following discussions.

The first merger wave (1893-1904) is argued to be the foundation of the industrial development in the US. ${ }^{241}$ The main industries that participated

240 Nelson, Merger Movements in American Industry, 1895-1956, supra note 234, at 5-6.

241 Gaughan, Mergers, Acquisitions, and Corporate Restructurings, supra note 237, at 23; Larry D. Qiu \& Wen Zhou, Merger Waves: A Model 
in that merger wave were manufacturing, mining, ${ }^{242}$ and oil industries. Ralph Nelson has clearly identified most of the manufacturing industries as follows: (1) bituminous coal production, (2) chemical production, (3) fabricated metal production, (4) food processing, (5) oil production, (6) machinery production, (7) primary metal products, and (8) transportation equipment. ${ }^{243}$

It was also reported that in $1901 \mathrm{~J}$. P. Morgan succeeded in creating the first American 1 billion US dollar corporation by means of a merger of 785 corporations, which became the U.S. Steel Corporation. ${ }^{244}$ Moreover, it was also reported that during the first wave 1,800 corporations were merged to form only 137 corporations, and it has been claimed that this wave was mainly fueled by a complete transportation network i.e. railroad. ${ }^{245}$ Others held that the lax enforcement of the Sherman Act catalyzed business owners to enter into more horizontal mergers, i.e. mergers between corporations operating at the same level of a certain industry. ${ }^{246}$

On the other hand, scrutinizing the data during that same period, as shown in Figure 1.3, reveals that the total number of vertical mergers, i.e. mergers between corporations operating at different levels of a certain industry, ${ }^{247}$ was higher if compared to the total number of horizontal mergers during the same period. Therefore, the lax nature of the antitrust enforcement cannot be considered as the main driving force of that first merger wave.

In the same context, it has been claimed that the main cause fueling the first merger wave was the "race to the bottom" between the American states to attract corporations to relocate their investments, as was previously noted; Rockefeller moved Standard Oil to New Jersey, and many others did the same due to the enactment of the General Corporation Act, ${ }^{248}$ which allowed unlimited corporation size and mergers. It was even

of Endogenous Mergers, 38 The RAND Journal of EConomics 214, at 214 (2007).

242 Cole, M\&A Titans: The Pioneers Who Shaped Wall Street's Mergers and Acquisitions Industry, supra note 239, at 2.

243 Gaughan, Mergers, Acquisitions, and Corporate Restructurings, supra note 237 , at 23 .

244 DePamphilis, Mergers and Acquisitions Basics: All You Need to Know, supra note 238 , at 24.

245 WeStON \& WeAver, Mergers and Acquisitions, supra note 239, at 7.

246 DePamphilis, Mergers and Acquisitions Basics: All You Need to Know, supra note 238 , at 24 .

247 Id. at 14.

248 New Jersey General Corporation Act of 1896. 


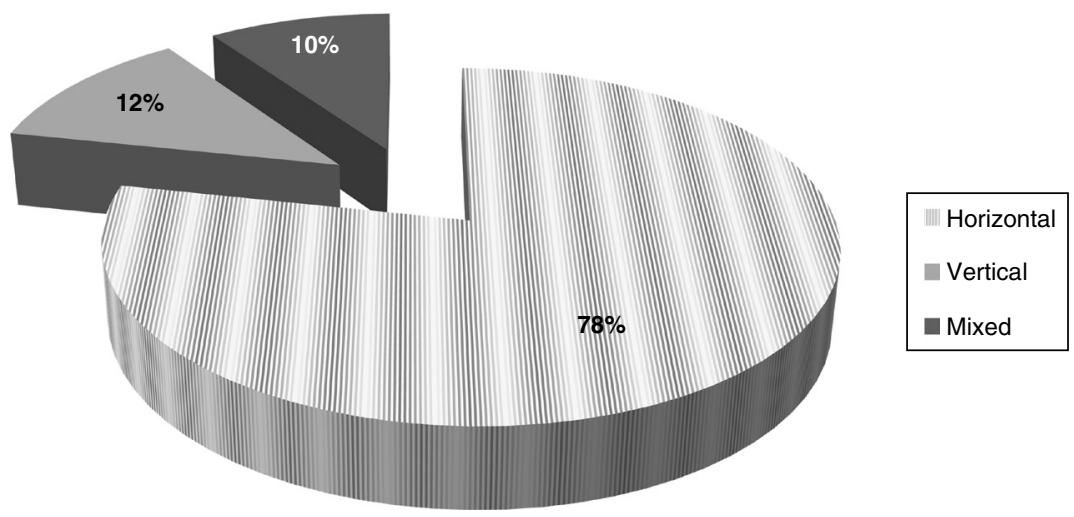

Source: Data retrieved from Neil Fligstein, The Transformation of Corporate CONTROL at 72 (Harvard University Press. 1990).

Figure 1.3 First merger wave classification

asserted that Delaware won the race by enacting an even more friendly Corporation Act in 1899. ${ }^{249}$

The second merger wave (1916-1930) was characterized by a significant increase in the number of vertical mergers, and generally speaking analyzing the transaction reveals that the manufacturers tried to control or at least integrate the means of distribution. ${ }^{250}$ For instance, Ford Corporation ${ }^{251}$ owned steel factories, railroad, and car manufacturing lines. ${ }^{252}$ Meanwhile, it has been claimed that this wave was a horizontal merger wave, but that claim was not based on any facts or data other than the fact Samuel Insull created a utility corporation that was operating in 39 US states. ${ }^{253}$

Generally speaking, this second wave was mainly fueled by three

249 Micklethwait \& Wooldridge, The Company: A Short History of a Revolutionary Idea, supra note 27, at 68, 69. Delaware General Corporation Law of 1899 (21 Del. Laws-273).

250 Weston \& WeAVER, Mergers and Acquisitions, supra note 239, at 8.

251 Ford is a US automobile manufacturing corporation that was founded in 1903. For more information about Ford and its history visit its official website at http://corporate.ford.com/our-company?gnav=footer-aboutford (last visited on December 1, 2017).

252 Cole, M\&A Titans: The Pioneers Who Shaped Wall Street's Mergers and Acquisitions Industry, supra note 239, at 2.

253 Samuel Insull (November 11, 1859-July 16, 1938). DePamphiLis, Mergers and Acquisitions Basics: All You Need to Know, supra note 238, at 25. 
factors, the first one was the post-World War I booming economy, ${ }^{254}$ the second was the development of communication means, especially the radio, as reliable marketing tools, ${ }^{255}$ and the third was the advancement of transportation means. ${ }^{256}$ George Stigler ${ }^{257}$ claimed that the trend during this second wave turned from merge to monopoly to merge to oligopoly, which means that the market is dominated by a number of corporations, not only one. ${ }^{258}$

The third merger wave (1955-1970) was first characterized by a trend, described as the conglomerate transactions; the appeal of the traditional vertical and horizontal mergers faded away, and corporations from different unrelated industries started to go through mergers. ${ }^{259}$ It was also characterized by making use of the tools of mathematics in the financial markets, for the purposes of gaining outstanding profits, which was then known as "financial engineering." For instance, most of the corporations during that wave were driven to go through mergers of any kind, as soon as a new tool or principle of gaining profits was revealed, for example most of the mergers during that wave were driven by the profits gained under the model of the Price-Earnings Ratio (hereinafter P/E), ${ }^{260}$ which will be discussed later along with the other mergers incentives.

Accordingly, it has been claimed that banks, unlike in the first two waves, did not finance this wave, whereas businesses heavily relied on the financial engineering tools as the new financing option. ${ }^{261}$ It was also

254 Gaughan, Mergers, Acquisitions, and Corporate Restructurings, supra note 237, at 28; DePamPhiLIs, Mergers and Acquisitions Basics: All You Need to Know, supra note 238, at 25.

255 WeSTON \& WeAVER, Mergers and Acquisitions, supra note 239, at 8.

256 Gaughan, Mergers, Acquisitions, and Corporate Restructurings, supra note 237 , at 30 .

257 George Stigler (January 17, 1911-December 1, 1991) was an economist who received the Nobel Memorial Prize in Economic Sciences in 1982 and was also Professor of Economics at Chicago University. He is considered one of the leaders of the Chicago School of Economics.

258 Gaughan, Mergers, Acquisitions, and Corporate Restructurings, supra note 237, at 28; Oliver Black, Conceptual Foundations of Antitrust at 24 (Cambridge University Press. 2005), citing George J. Stigler, Monopoly and Oligopoly by Merger, 40 The American ECONOMIC Review 23 (1950).

259 Weston \& WeAver, Mergers and Acquisitions, supra note 239, at 8; BlaCK, Conceptual Foundations of Antitrust, supra note 258, at 24.

260 DePamphilis, Mergers and Acquisitions Basics: All You Need to Know, supra note 238, at 25; Gaughan, Mergers, Acquisitions, and Corporate Restructurings, supra note 237, at 35-36.

261 Gaughan, Mergers, Acquisitions, and Corporate Restructurings, supra note 237 , at 31 . 


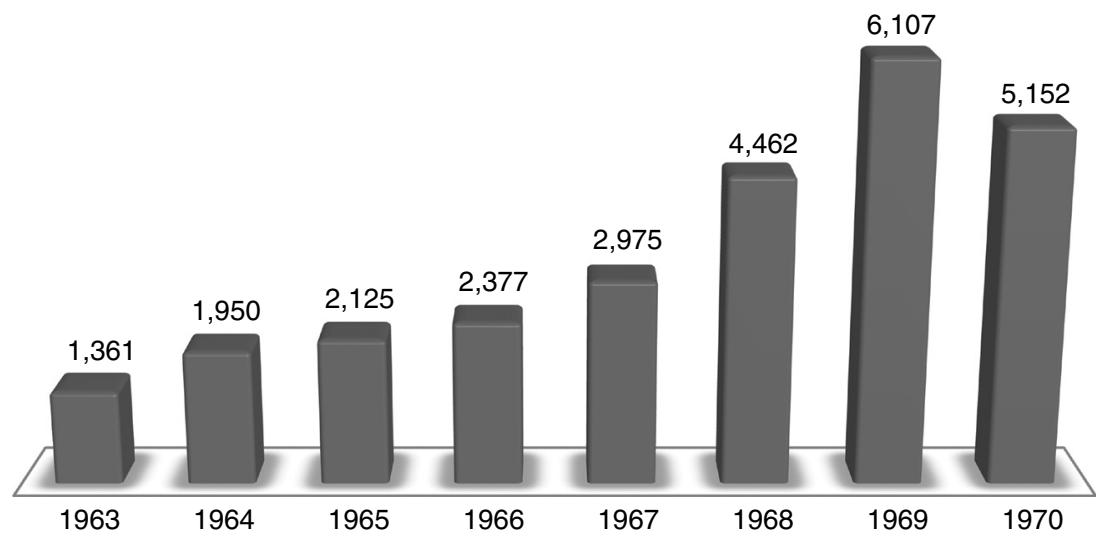

Source: Data retrieved from Patrick A. Gaughan, Mergers, Acquisitions, And Corporate Restructurings at 33 (3rd ed., Wiley. 2002).

Figure 1.4 Number of reported mergers during the period 1963-1970

reported that the strict enforcement of antitrust laws, the Clayton Act of 1914 and its amendments ${ }^{262}$ as a reinforcement of the Sherman Act, was directly affecting the merger activity following the second wave. ${ }^{263}$ Strictly speaking that could not be considered as the fuel of that wave, but it could easily be considered as shaping the conglomerate structure to avoid antitrust violations. It was also reported that this wave reached its peak in 1969 with 6,107 mergers reported during that year, as shown in Figure 1.4, and it was also reported that by the end of this wave 15 of the top 200 corporations of the US Fortune 500 were merged conglomerates. ${ }^{264}$

The fourth merger wave (1980-1990) was characterized by the unfriendly or hostile takeover, which briefly means entering into a merger transaction without the consent of one party or more. ${ }^{265}$ The advanced financial engineering trend, during this period, played a greater role in that regard, especially by making use of the new financing tools like junk bonds ${ }^{266}$ and

\footnotetext{
26215 U.S.C. $\$ \S 12-27$.

263 Gaughan, Mergers, Acquisitions, and Corporate Restructurings, supra note 237 , at 29 .

264 Micklethwait \& Wooldridge, The Company: A Short History of a Revolutionary Idea, supra note 27, at 121.

265 Cole, M\&A Titans: The Pioneers Who Shaped Wall Street's Mergers and Acquisitions Industry, supra note 239, at 2; DePAMPHILIS, Mergers and Acquisitions Basics: All You Need to Know, supra note 238, at 25.

266 Junk bonds are high-default-risk bonds, but offer very high yields.
} 


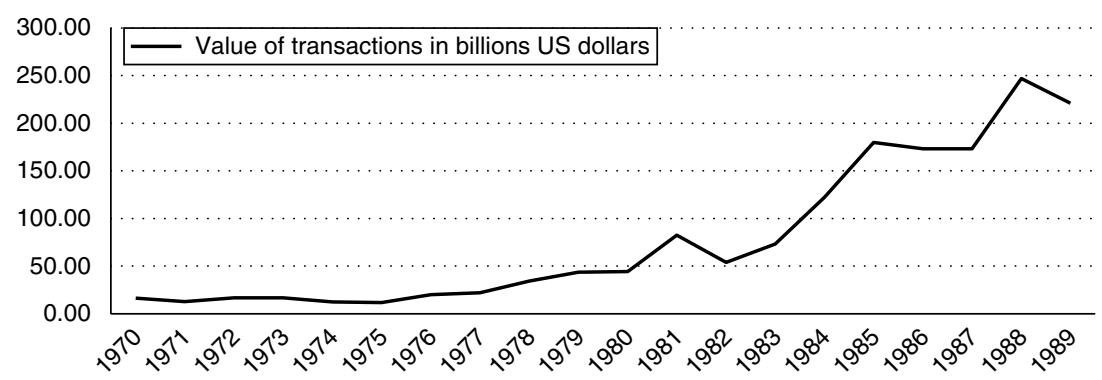

Source: Data retrieved from Lokey Houlihan \& Howard Zukin, Mergerstat Transaction Roster (1998).

\section{Figure 1.5 Value of transactions during the period 1970-1989}

leveraged buyouts ${ }^{267}$ (hereinafter LBO). ${ }^{268}$ On the other hand, it was also claimed that these very financing tools i.e. the junk bonds, were a double sword, financing most of the LBO during this wave, and when they collapsed by the end of the period, they brought the wave to an end. ${ }^{269}$

Analyzing the data, specifically comparing the number of mergers and the value of the transactions that were conducted during the third wave with the number of mergers and the value of the transactions of the fourth wave, reveals a very surprising result: Despite the fact that the number of mergers conducted in the fourth wave was very low if compared to the number of mergers conducted in the third wave, the value of the transactions in the fourth wave was very high compared to the value of the transactions in the third wave, as Figures 1.5 and 1.6 illustrate.

The fifth merger wave (1992-2000) was characterized by the essence of scaling and going global as a main goal, and that was very appealing; that period was even known as "the age of the Strategic MegaMerger," 270 but a very significant percentage of the mergers was limited to only five or six industries. ${ }^{271}$ Moreover, it has been reported that the merger activities during this wave set new records as regards the

\footnotetext{
267 For more details about LBO see infra p.80.

268 Weston \& Weaver, Mergers and Acquisitions, supra note 239, at 8.

269 Gaughan, Mergers, Acquisitions, and Corporate Restructurings, supra note 237 , at $50-51$.

270 Cole, M\&A Titans: The Pioneers Who Shaped Wall Street's Mergers and Acquisitions Industry, supra note 239, at 2; DePAmPHILIS, Mergers and Acquisitions Basics: All You Need to Know, supra note 238, at 27; Gaughan, Mergers, Acquisitions, and Corporate Restructurings, supra note 237, at 51.

271 Weston \& WeAVer, Mergers and Acquisitions, supra note 239, at 8.
} 


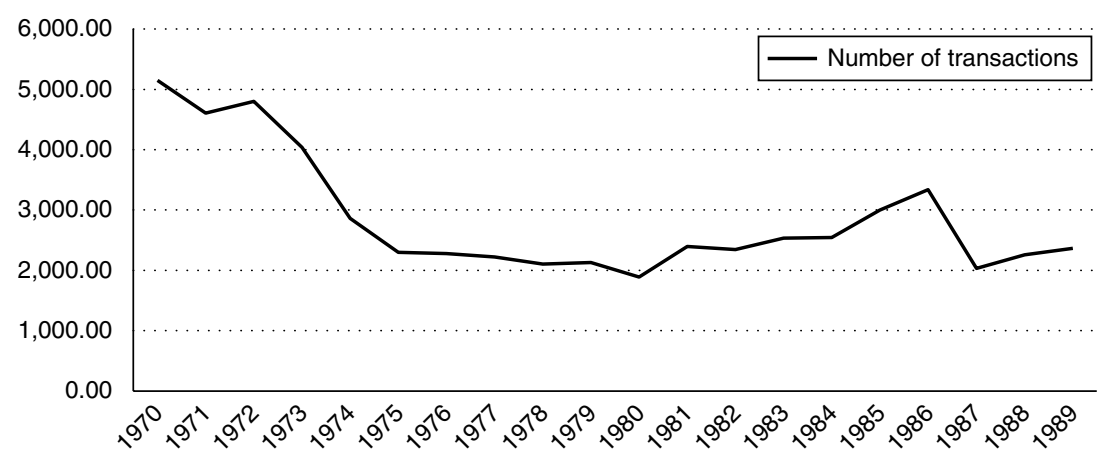

Source: Data were retrieved from Patrick A. Gaughan, Mergers, Acquisitions, And Corporate Restructurings at 50-51 (3rd ed., Wiley. 2002).

Figure 1.6 Number of transactions during the period 1970-1989

transaction values and even their number. ${ }^{272}$ In the same context, it was also reported that during this merger wave, the benefits of mergers were undoubtedly expected and mergers, in addition to some similar forms of transactions, created approximately 20 percent of the American Fortune 1,000 corporations. ${ }^{273}$

Meanwhile, and because of the fact that mergers were scaling and going on all over the world, other countries experienced relatively the same merger wave, and it could easily be claimed that, starting from the fifth wave, mergers were expanding and crossing borders, and that became a fact not just a hope. Despite the fact that the data in Figure 1.7 reveals that other countries were not experiencing the same merger wave in the same magnitude as the US, that might confirm at the same time that the mergers turned out of the American box and spread across the globe. It was also reported by the United Nations Conference on Trade and Development (hereinafter UNCTAD) that during this wave, the number of mergers grew by 42 percent per year. ${ }^{274}$

The sixth merger wave (2002-2007) started with the "rebirth" of the LBO, the heavy use of financial engineering tools in general, and very

272 DePamphiLis, Mergers and Acquisitions Basics: All You Need to Know, supra note 238, at 27.

273 Micklethwait \& Wooldridge, The Company: A Short History of a Revolutionary Idea, supra note 27, at 145-146.

274 United Nations Conference on Trade and Development, Cross-border Mergers and Acquisitions And Development at xix (United Nations. 2000). 


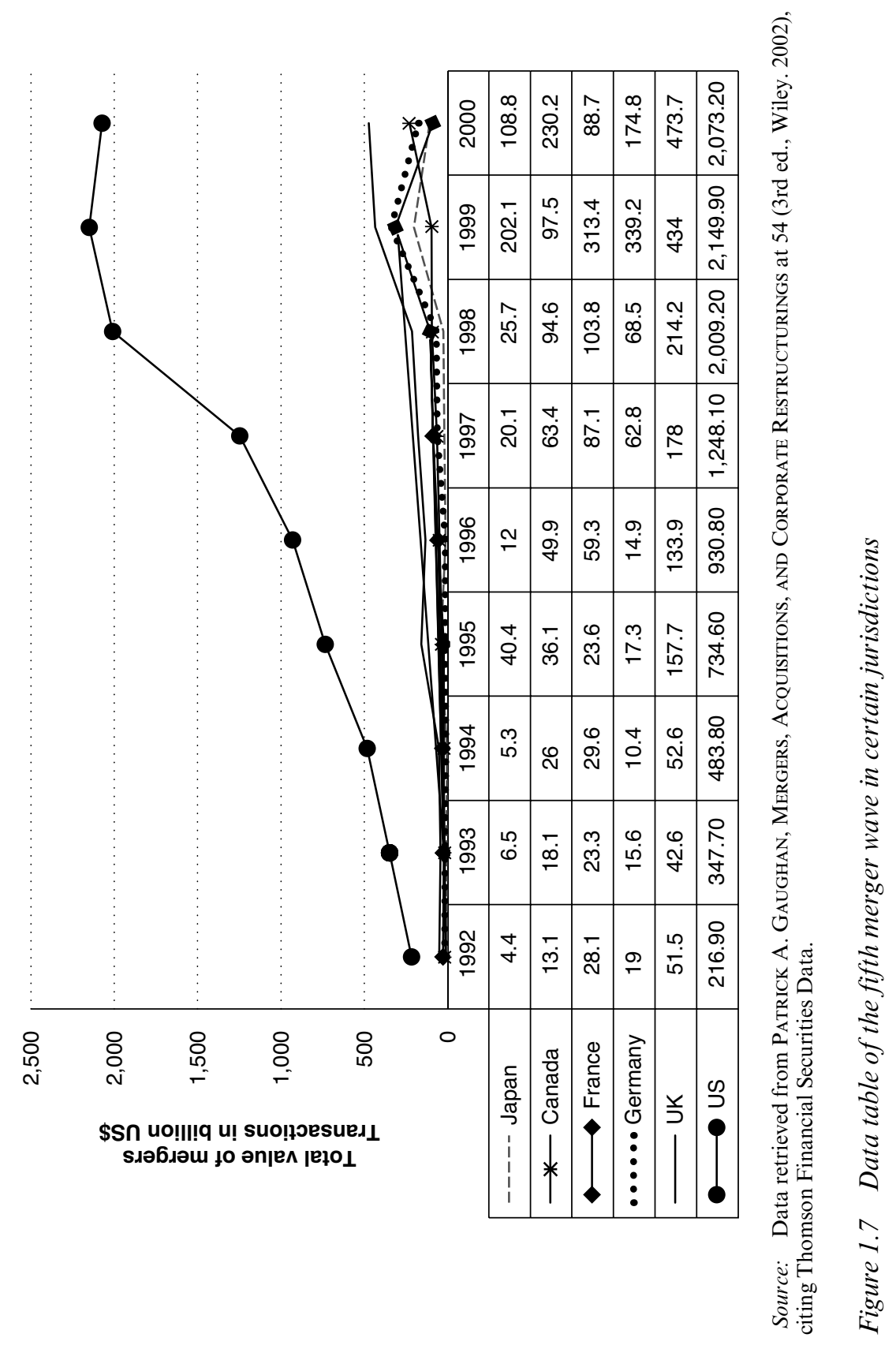


complicated debt transactions, and it ended with the world financial crisis in $2007 .{ }^{275}$ The globalization spirit, and the maturity of the previous mega mergers corporations and the increase of their appetite to go global characterized this wave; moreover mergers transactions started to be more complicated. ${ }^{276}$ Generally speaking, it is not easy to scrutinize and understand the complex trends and the characteristics of mergers starting from this wave, which requires painstaking and dedicated efforts, but the following discussions will be an eye-opener as to what is going on, starting from this relatively recent period.

\section{(e) Multinational corporations}

The German Idealism philosopher Hege ${ }^{277}$ asserted that the state is and always will be the centerpiece in any society, while both Adolf Hitler ${ }^{278}$ and Vladimir Lenin ${ }^{279}$ argued that it would be the political party, and others maintained it would be some other institution like the Church. ${ }^{280}$ None of those claims seems to be materializing, and nor what Samuel Madden, a famous Irish satirist in the 17th century, ironically expected, as described in one of his novels, that two titan corporations would rule the world in the 20th century. 281

It is undoubtedly true that the development of the modern form of corporation was not accidental, ${ }^{282}$ but the corporation idea was steadily developing throughout centuries not decades, as was shown during the previous discussions. In that context, it could easily be claimed that the

275 DePamphilis, Mergers and Acquisitions Basics: All You Need to Know, supra note 238 , at 27.

276 See generally 2008 International Mergers \& Acquisitions: Creating VAlue In AN INCREASINGly COMPlex Corporate EnVIRONMENT, 2008, available at Financier Worldwide.

277 Georg Wilhelm Friedrich Hegel (August 27, 1770-November 14, 1831) was a German philosopher, and a major figure in German Idealism. His historicist and idealist account of reality revolutionized European philosophy and was an important precursor to continental philosophy and Marxism.

278 Adolf Hitler (April 20, 1889-April 30, 1945) was an Austrian-born German politician and the leader of the Nazi Party and the National Socialist German Workers Party. He was chancellor of Germany from 1933 to 1945.

279 Vladimir Lenin (April 22, 1870-January 21, 1924) was a Russian communist, politician, and political theorist.

280 Micklethwait \& Wooldridge, The Company: A Short History of a Revolutionary Idea, supra note 27, at xiv-xv.

281 Samuel Madden (1687-1765) was an Irish author, and for more details about what he expected for the 20th century during his time see generally SAMUEL Madden, Memoirs of the Twentieth Century (1733).

282 Williston, HaRVARD LAW REVIEW, supra note 26, at 113. 
proliferation of the latest breakthrough of corporation history, which is the multinational corporations, was an inevitable result of the merger waves; this breakthrough is worth studying.

During the third merger wave, the EU countries woke up to a nightmare; most of the giant American corporations like IBM, Heinz, Kellogg, Ford and P\&G invaded the EU markets, and many American corporations practiced hostile takeovers toward European corporations. ${ }^{283}$ It was also reported even before that, i.e. from the end of World War I or the beginning of the second merger wave and before the third merger wave, the financing institutions contributed to finance corporations becoming global, for instance that period saw the expansion of the utility sector, especially electricity, with the help of multinational corporations. ${ }^{284}$

It was also reported that by the sixth merger wave the estimated number of multinational corporations across the globe was 65,000 , and the expansion was not limited to giant corporations because small corporations were also given the opportunity to finance their deals and to mimic giant corporations. ${ }^{285} \mathrm{It}$ is not clear if the inevitable result of the proliferation of multinational corporations was a driving force for the convergence of the different systems of corporate laws across the globe, or the convergence of the corporate laws was the fuel that drove the corporations to go global. It was even maintained that since the origin of the corporation, the corporate law was founded and designed to be a global tool. ${ }^{286}$

All that was the main reason why corporations in general, and especially multinational corporations, shared the same characteristics across the globe; the people either at "home or abroad" never loved them, however to the contrary, they were also considered as a "force for good ... [and] they have given up sinning quite so egregiously." ${ }^{287}$ In addition to that, it was even claimed that the convergence of the corporate laws across the globe was characterized by taking the same form as the merger waves; it was also episodic and constituted "cyclic" movements or waves. ${ }^{288}$

Finally, it is noteworthy that it was argued that there is a corporate

\footnotetext{
283 Micklethwait \& Wooldridge, The Company: A Short History of a Revolutionary Idea, supra note 27, at 171.

284 William J. Hausman, et al., Global Electrification: Multinational Enterprise and International Finance in the History of Light and Power, 1880s-1914, 58 REVUE ÉCONOMIQUE 175, at 176, 186-187 (2007).

285 Micklethwait \& Wooldridge, The Company: A Short History of a Revolutionary Idea, supra note 27, at 173-174.

286 Gevurtz, Washington Law Review, supra note 128, at 479-480.

287 Micklethwait \& Wooldridge, The Company: A Short History of a Revolutionary Idea, supra note 27, at 176-178.

288 Gevurtz, Washington Law ReviEW, supra note 128, at 485-486.
} 
raid that is invading the globe, for example JPMorgan Chase \& Co. is the result of merger transactions between more than 1,000 of its predecessors, which were conducted over almost the last century. ${ }^{289}$ Furthermore, by the end of the fifth merger wave the 100 biggest economies in the world were all corporations. ${ }^{290}$ Generally speaking, the corporation has turned out to be the largest and most powerful institution throughout history. ${ }^{291}$ Meanwhile, the government or the state across the globe was not standing idle toward the corporate raid, there was always some sort of control or at least relation between these two powerful institutions, and the story of this relation will be considered in detail in the following discussion.

\section{Relation Between State and Corporations}

Throughout history different forms or models of the state were developed, for instance in early history, i.e. the Middle Ages, the ruler, whether a king, queen, or even the Church, was the owner of everything. ${ }^{292}$ Scrutinizing the different models from the perspective of the relation between the state and the corporation reveals that throughout history there was always some sort of relation between them. At one end of the spectrum that relation was that the state was fully controlling the corporation, either by granting the creation of the corporation itself, by licensing its practices, or by overseeing the corporation as a regulator, and at the other end of the spectrum the state was giving a hand to help the corporation, surviving by means of subsides and some other helpful tools.

Taking into account that the corporation is the key player in the economy, it has always been the focus of attention of governments. In other words, the aforementioned relation spectrums can be encapsulated in this quotation by Ronald Reagan ${ }^{293}$ : "Government's view of the economy could be summed up in a few short phrases: If it moves, tax it. If it keeps moving, regulate it. And if it stops moving, subsidize it." 294 On the other hand, the corporation has played different roles throughout history, and

289 J. P. Morgan Chase, The History of JPMorgan Chase \& Co: 200 Years OF LEADERSHIP IN BANKING at 1 (JPMorgan Chase \& Co ed., JPMorgan Chase \& Co. 2008).

290 Braithwaite \& Drahos, Globalisation of Corporate Regulation and Corporate Citizenship, supra note 43, at 4.

291 Kent Greenfield, The Failure of Corporate Law: Fundamental Flaws and Progressive Possibilities at 4 (University of Chicago Press. 2006).

292 BRAUDEL, The Wheels of Commerce, supra note 45, at 519.

293 Ronald Wilson Reagan (February 6, 1911-June 5, 2004) was an American actor and politician, and the 40th president of the United States.

294 President Ronald Reagan United States Office of the Federal 
accordingly the following discussion will be an overview of the stages of those different roles, and how the relation with the state was developed.

\section{(a) Early history and feudalism}

Despite the fact that the information concerning the early history of feudalism $^{295}$ as a form of relation between the state and corporations is sometimes contradictory and in other instances unclear, the following discussion will continue to reveal the effect of feudalism on the development of the corporation as an idea. At first glance one might think that feudalism has no effect or even is not related to the development of corporations, but analyzing the history of feudalism reveals that the relation started as land ownership issues, and then turned into the ruler granting the right to create the corporation.

First we consider the history before feudalism, where the first reported relation between one form of the state, which was represented by the temple, and the landowners, was just after the Sumerians had developed the concept of land ownership around 3000 BC. By entering into agreements, the temple was granted the right to be involved, and it was also claimed that the temple practiced a form of control or supervision over all the issues concerning land ownership. ${ }^{296}$

Then during the Middle Ages, an important breakthrough in that relation happened; it was the development of feudalism, an idea of the Norman Conquests, ${ }^{297}$ where there was a ranked system of land ownership and control of society. It started with the lord or noble who was in the highest rank and it ended with the fief in the lowest rank. ${ }^{298}$ In that context it was held that feudalism paved the way for the development of capitalism, while others asserted that it was the rights and privileges granted to certain lords or nobles that drove the development of capitalism, in other words the nobles and lords found feudalism "a favourable climate in which ... [they could] 'institutionalize their own position."' 299

\footnotetext{
Register, Public Papers of the Presidents of the United States, Ronald REAGAN: 1981-1988-89 at 1109 (U.S. G.P.O. 1982).

295 The definitions of feudalism are contradictory and inconsistent; for more details see generally Elizabeth A. R. Brown, The Tyranny of a Construct: Feudalism and Historians of Medieval Europe, 79 The American Historical Review 1062, at 1063-1088 (1974).

296 Micklethwait \& Wooldridge, The Company: A Short History of a Revolutionary Idea, supra note 27, at 3-4.

297 CATER, A History of English Legal Institutions, supra note 13, at 16.

298 Brown, The AmEricAn Historical Review, supra note 295, at 1071 (1974).

299 BRAUDEL, The Wheels of Commerce, supra note 45, at 594.
} 
To elaborate more on how they institutionalized their positions, the nobles were granted rights to collect feudalism fees or taxes on behalf of the ruler, and in time they figured out that these tasks should be performed under some sort of institution in order to stand for a long time, and consequently they recognized that the idea of creating a corporation would help them protect their personal interests. It has been reported that the oldest corporation for that purpose was Aberdeen Harbour, which was created in $1136 .{ }^{300}$ The City of London Corporation was another good example, which was also created in the 12th century, and interestingly both of these two corporations are alive today. ${ }^{301}$

The idea of seeking that institutional framework became widespread and proliferated in time, and it was even reported that any group of people that planned to avoid the feudalism system focused their efforts on how to be granted a corporation right, for instance by that time many "groups," like boroughs, guilds, and universities, were granted the right to be a corporation. ${ }^{302}$ Moreover, literally most of the towns in the UK were granted the right to be corporations at that period. ${ }^{303}$

Meanwhile, the widespread use of corporations was not serving the ruler's interests because, as previously shown, one of the old corporations' characteristics was the right of perpetual succession, which means that whenever a group of people are granted such corporation rights they will avoid the feudalism system forever. Accordingly Edward I enacted what was known as the Statute of Mortmain in 1279 in order to control the amount of land that could be owned by corporations. It should be noted that despite the fact that the Statute of Mortmain could clearly be considered as a form of state control over corporations, it did not stop the wide spread of the idea of the corporation. ${ }^{304}$

300 For more information about the current activities and news of the Aberdeen Harbour corporation, see its official website: http://www.aberdeen-harbour.co.uk (last visited December 1, 2017).

301 Micklethwait \& Wooldridge, The Company: A Short History of a Revolutionary Idea, supra note 27, at 12 . For more information about the current activities and news of the City of London Corporation, see its official website: https://www.cityoflondon.gov.uk (last visited December 1, 2017).

302 Stewart Kyd, A treatise on the Law of Corporations at 63 (printed for J. Butterworth. 1793-1794). Stewart Kyd published his definitive treatise on the law of corporate boroughs in two volumes in 1793-94.

303 Williams, American University LAW Review, supra note 23, at 377.

304 Micklethwait \& Wooldridge, The Company: A Short History of a Revolutionary Idea, supra note 27, at 13 . 


\section{(b) Granting charters and monopolies ${ }^{305}$}

Most of the corporations that were created under the feudal system were granted certain exclusive rights or monopoly in order to perform their tasks. Such monopoly actually granted those corporations a privilege to accumulate profits, for instance it has been reported that some corporations made profits of more than 150 percent. ${ }^{306}$ However, the monopolies granted to the corporations were not limited to the feudal corporations because monopolies were granted to other private corporations and individuals in order to practice trade. The first private corporation to be granted a charter was Stora Enso of Sweden, ${ }^{307}$ which was created in $1347^{308}$ and, as previously mentioned, the first joint-stock corporation to be granted a charter was the Muscovy Company, which was founded in $1553-55.309$

As previously shown, Sir Edward Coke and others claimed that the corporation, in early times, was created by one of the following instruments: (1) common law, (2) charter issued by the king, (3) an Act of Parliament, or (4) prescription. ${ }^{310}$ Meanwhile, it is noteworthy that for a corporation to be created by prescription, i.e. by long standing or by common law, it should not practice trade. Examples of those corporations not practicing trade are the borough, the Church, and the parish, and even in those cases

305 For an early definition of the term monopoly by Sir Edward Coke see Edward Coke, The Third Part of the Institutes of the Laws of England Concerning High Treason, and other Pleas of the Crown, and Criminall CAuses at 181 (printed by M. Flesher, for W. Lee and D. Pakeman. 1644). It was defined as "an Institution, or allowance by the King, by His Grant, Commission, or otherwise, to any person or persons, bodies politic or corporate, of or for the sole buying, selling, making, working or using of anything, whereby any person or persons, bodies politic or corporate are sought to be restrained of any freedom, or liberty that they had before or hindered in their lawful trade."

306 BRAUDEL, The Wheels of Commerce, supra note 45, at 343.

307 For more information about the current activities and news of the Stora Enso corporation, see its official website: http://www.storaenso.com (last visited December 1, 2017).

308 Micklethwait \& Wooldridge, The Company: A Short History of a Revolutionary Idea, supra note 27, at 12.

309 Gevurtz, Washington Law Review, supra note 128, at 48; BRAudel, The Wheels of Commerce, supra note 45, at 439, 449; MicklethWAIT \& WoOLDRIDGE, The Company: A Short History of a Revolutionary Idea, supra note 27, at 18.

310 COKE, The Selected Writings and Speeches of Sir Edward Coke, supra note 20, at 363. AtKIns, The Law of Corporations Containing the Laws and Customs of all the Corporations and Inferior Courts of Record in England, supra note 101, at 8-9. SHEPPARD, Of Corporations, Fraternities, and Guilds, supra note 96, at $6-8$. 
it was held that for such a corporation to be created by prescription, it should hold an unstated "assent of the King." 311

In the same context, it should be noted that granting the right of incorporation by the ruler or by Parliament was almost the same, and most of the early scholars did not differentiate between them, but it was asserted that granting the right to incorporation by the ruler was more appreciated in society, because it was considered that Parliament was just an agent of the ruler, so it was more prized to be granted the right from the principal. ${ }^{312}$ In that regard it is noteworthy that if the corporation was created by an Act of Parliament it was known as a "statutory company." 313

Meanwhile, it has been reported that the instrument issued by the ruler to grant a monopoly for a group or corporation was named a "charter," while it was named as a "letter of patent" if it was granted to an individual. ${ }^{314}$ While some might claim that such distinction is not important, it is important because the fact that granting a monopoly for an individual will be for his own good was not accepted by the people in society and vice versa. ${ }^{315}$ That fact was realized early by Francis Bacon in his speech before Parliament on November 20, 1601 as he said: "If her Majesty ... make patent or a monopoly into any of her servants, that we must go and cry out against; but if she grant it to a number of burgesses, or a corporation, that must stand, and that, forsooth, is no monopoly." 316

Moreover, it has been claimed that most of the successful trading corporations were created at first as monopolies, ${ }^{317}$ and without the monopoly rights most of those corporations would not realize any profits at all. ${ }^{318}$ Likewise, other individual merchants who were not granted any

311 DAvis, Essays in the Earlier History of American Corporations, supra note 86 , at 6.

312 Eaton, The Yale Law Journal, supra note 19, at 282.

313 Pettet, Company Law, supra note 125, at 18.

314 Laski, Harvard Law Review, supra note 17, at 584. Davis, Essays in the

Earlier History of American Corporations, supra note 86, at 6.

315 For more details about the history of monopoly during the period of 1780-1860 see Morton J. Horwitz, The Transformation of American Law, 1780-1860 at 109-139 (Harvard University Press. 1977).

316 George Walter Prothero, Select Statutes and Other Constitutional Documents Illustrative of the Reigns of Elizabeth and James I at 111 (3rd ed., Clarendon Press. 1906).

317 BRAUDEL, The Wheels of Commerce, supra note 45, at 443.

318 Smith, An Inquiry Into the Nature and Causes of the Wealth of Nations, supra note 112 , at 1008 . 
letter of patent and also most of the public, were all suffering from these monopolies. This led to a great debate among people everywhere and most importantly in the UK Parliament, especially because of the increase in prices and the poor quality of the goods offered by corporations that were granted monopolies during that period. The debate was ended by the enactment of the Statute of Monopolies ${ }^{319}$ in 1623, which clearly prohibited certain types of monopolies. ${ }^{320}$

The right to grant other types of monopolies which were permitted under the Statute of Monopolies was heavily abused by the king at that time, to the extent that it has been reported that the terms "incorporated" and "monopoly" were synonyms in the UK, and that actually led to a reservation of the right to grant monopolies only to Parliament in 1688. ${ }^{321}$ However, the Statute of Monopolies was revoked in 1844 when the state realized that granting a monopoly was not the problem and that the problem was the abuse of the monopoly rights. Consequently, that is the principle adopted nowadays in the UK, under the Competition Act of 1998 and the Enterprise Act of 2002. ${ }^{322}$

It was also reported that all the previously mentioned developments, of granting the incorporation by a ruler charter or by Act of Parliament, were also taking effect in the American Colonies until their independence was declared. ${ }^{323}$ After independence, the development of the creation of corporations was slightly different in the US than the UK, for instance it has been reported that according to a Federal Circuit Court decision in 1771 , the creation of a corporation by prescription was more accurately described in the US and was also limited only to "religious, charitable, or literary purposes." 324

Granting the charter was not limited to the ruler and the parliament only in UK territories, but it was also reported that the parliament in the American Colonies practiced that right as early as 1652 . For example the Massachusetts General Court granted the people of Boston the right to form corporations in order to support themselves with utilities such

\footnotetext{
319 Statute of Monopolies 1623, Chapter $321 \mathrm{Ja} 1$.

320 Colino, Competition Law of the EU and UK, supra note 185, at 4-5.

321 Hein, The University of Toronto LAW Journal, supra note 27, at 137.

322 Colino, Competition Law of the EU and UK, supra note 185, at 5.

323 DAvis, Essays in the Earlier History of American Corporations, supra note 86 , at 7 .

324 Samuel Hazard, The Opinion of the Circuit Court of the United States, in and for the Eastern District of Pennsylvania, on the Will of Sarah Zane, a member of the Society of Friends, in Hazard's Register of Pennsylvania at 308-309 (Samuel Hazard ed. 1834).
} 
as water. ${ }^{325}$ In the same context, too many corporations were chartered by the parliament in the US after independence, most notably for the purpose of developing railroads. This was known as "railroad mania"326 and by the end of the 18th century most of the US states were involved in granting corporation charters for all purposes. ${ }^{327}$ It is noteworthy here that the Economist started in its first issue by designating a small portion of the stock market column to this, and then it became a nine-page section designated only for the railroad stock market in $1845 .^{328}$

Finally, the previous discussion shows that both the ruler and the parliament were only controlling the right to incorporate or grant monopolies, as both of the terms were almost synonymous, but also both of them were trying to take a bigger role in that regard, and at the same time the public and non-incorporated groups were suffering from the abuse of the rights granted to the corporations. That relation between the state, represented by the ruler and the parliament, and the corporation did not stop there; the state decided not only to control the creation of the corporation and the rights granted to it, but also to make use of it, as will be scrutinized in the following discussion.

\section{(c) Corporation as a financing institution}

Surprisingly, it has been reported that at the end of the 17 th century and the beginning of the 18 th century the state was going "hand in hand" with corporations, nothing was forbidden by that time in the commercial community, and the state even "turn[ed] a blind eye" if something went wrong. ${ }^{329}$ Meanwhile, it might be foreseeable that if someone was well informed about what the state was planning to do, the state introduced such flexibility and cooperation, but that was not for free, something should be given back in return, and that will be revealed in this discussion.

The idea of converting the state's debt into tradable or transferable bonds was first invented in Naples in the 17th century by Neapolitan Lorenzo Ponti in $1653 .{ }^{330}$ The state usually used the debt to help it

\footnotetext{
325 DAvis, Essays in the Earlier History of American Corporations, supra note 86 , at 89 .

326 Braithwaite \& Drahos, Globalisation of Corporate Regulation and Corporate Citizenship, supra note 43, at 10.

327 Horwitz, The Transformation of American Law, 1780-1860, supra note 315 , at 109 .

328 Micklethwait \& Wooldridge, The Company: A Short History of a Revolutionary Idea, supra note 27, at 48-49.

329 Braudel, The Perspective of the World, supra note 15, at 206.

330 Braithwaite \& Drahos, Globalisation of Corporate Regulation and Corporate Citizenship, supra note 43, at 25.
} 
accomplish all the tasks that required financial resources, for instance it was used sometimes to finance war, ${ }^{331}$ other times to finance "quasigovernment" purposes, for example exploration in sea passage voyages. Meanwhile, despite the fact that the idea of securitization was a Neapolitan invention, the ruler in the UK decided to make heavy use of it, which led to the result that UK appeared to be a more successful country than other European countries, for instance France, during that period. 332

In order to consider the idea of securitization of the national debt as a landmark in the relation between the state and corporation, one more step is required, that of converting the debt into corporate shares, and that step was actually invented at the same time in both the UK and France. In France, the step was motivated by John Law, ${ }^{333}$ who, after he invented paper money, converted the debt bonds of the French government into a joint-stock corporation in 1729 . That corporation was the Mississippi Company and it handled the French government debt, which was so huge over time, especially after the war during the period from 1689 to 1714.334

In the UK, the position was almost the same. As previously shown Parliament announced on January 21, 1720 that the South Sea Company would handle the British government debt exclusively. ${ }^{335}$ Handling the debt of the state caused one of the biggest financial crises in the history and it was even named "[t]he drama of the South Sea Company." ${ }^{336}$ Similarly, the Mississippi Company also turned out to be a bubble that burst suddenly in the face of the investors who found no assets. ${ }^{337}$ However, it has been claimed that the "drama of the South Sea Company" did not reach the same peak of the Mississippi Company crisis.

Unfortunately, that stage of the relation between the state and the corporation was unsuccessful and it ended with an unhappy crisis. As

\footnotetext{
331 Braudel, The Wheels of Commerce, supra note 45, at 519.

332 Braithwaite \& Drahos, Globalisation of Corporate Regulation and Corporate Citizenship, supra note 43 , at 4.

333 John Law (April 21, 1671-March 21, 1729), a Scottish economist and gambler, invented paper money, and was responsible for the Mississippi Company crisis in France in 1720.

334 Micklethwait \& Wooldridge, The Company: A Short History of a Revolutionary Idea, supra note 27, at 28-29.

335 Id. at 31-32.

336 Arner, Southern Methodist University Law Review, supra note 27, at 33; Pettet, Company Law, supra note 125 , at 9.

337 Micklethwait \& Wooldridge, The Company: A Short History of a Revolutionary Idea, supra note 27 , at $30-31$.
} 
was previously mentioned, the Bubble Act was introduced by the British Parliament to survive the crisis and in fact it did-by prohibiting unchartered corporations and limiting the power of incorporating corporations only to Parliament-but that was at the expense of the economy and development of the corporation as an idea. In order to avoid those drawbacks, the relation between the state and the corporation developed to the next stage, which was the repeal of the Bubble Act and allowing individuals to incorporate corporations as easily by registration, as will be shown in the following discussion.

\section{(d) Incorporation by registration}

During the period of the mentioned financial crisis, the economies of most European countries were struggling, and that led the states to start some initiatives to restore their economies. Those initiatives mostly focused on removing all the internal customs, duties, and tolls. Those initiatives began in Spain as early as 1717 and France was the last county to introduce them in $1790 .{ }^{338}$ But it could easily be recognized that all the initiatives were modest, at least in their scope, and they did not deliver what was expected. That led to the following radical changes in the relation between the state and the corporation in order to restore the economy.

As was previously mentioned during the discussion of the South Sea Company and the Bubble Act, ${ }^{339}$ the British Parliament repealed the Bubble Act and enacted a new Act that permitted the creation of a new joint-stock corporation as easily as by registration. However, that was not applicable to corporations for all purposes, for instance joint-stock corporations for the purposes of practicing banking were not allowed to incorporate by registration, and that could be attributed to the fear of future crises that could have a similar effect as the crisis resulting from the use of the South Sea Company as a financing institution.

Starting from 1844, it was allowed for any individual to incorporate a joint-stock corporation by registration. ${ }^{340}$ In that context, it has been claimed that incorporating a new corporation just by registration had "truly arrived" by that time, and a new dimension was opened in the relation between the state and the corporation by adopting that liberalized approach. ${ }^{341}$ In fact that liberalized approach started by allowing the

\footnotetext{
338 BraUdel, The Perspective of the World, supra note 15, at 290.

339 See supra p.31.

340 Pettet, Company Law, supra note 125 , at 9.

341 Braithwaite \& Drahos, Globalisation of Corporate Regulation and Corporate Citizenship, supra note 43, at 10.
} 
incorporation by registration but it did not stop at that end, many other acts followed the same approach for a long period of time, for instance it has been reported that by 1856 , the limited liability principle was permitted by law, and that led to the proliferation of the incorporation and the economy in general. ${ }^{342}$

It is noteworthy that that liberalized approach was expanded to include industries other than trade. It mainly expanded to include banking; banks were granted the right to be incorporated as limited liability corporations in UK by the second half of the 19th century, and that liberalized approach was also borrowed by many other countries not only in Europe but across the globe. ${ }^{343}$ Meanwhile, for a number of reasons that liberalized approach was followed by another trend that was not in the same direction. The state started to plan for opening a new dimension in its relation with corporations, which was introducing more rigorous procedures in order to regain control over the corporations and make use of them. ${ }^{344}$

\section{(e) Protectionism}

By the end of the 19th century, it could easily be identified that many countries around the world, especially the US, fully realized the fact that they should step in and intervene in order to protect and support their own economies against any failure. In order to accomplish that, the state played two different roles; the first was the adoption of stricter policies toward its own domestic corporations and the second was the protection of its own domestic corporations against competing foreign corporations. In fact, supporting domestic corporations in order to grow was a prerequisite to benefiting from them, but in the meantime the state planned to bring corporations under its control, and that will be clearly shown in this discussion.

For instance, in the US, as was previously discussed, antitrust measures were introduced by the end of the 19th century in order to impose some sort of control over domestic corporations. On the other hand, it was also reported that the trend during that period in many countries like France and Germany was to impose trade barrier measures against foreign corporations, ${ }^{345}$ both fiscal barriers like tariffs and antidumping measures,

342 Pettet, Company Law, supra note 125, at 9-10, 23-24.

343 Braithwaite \& Drahos, Globalisation of Corporate Regulation and Corporate Citizenship, supra note 43, at 10.

344 Hein, The University of Toronto Law Journal, supra note 27, at 151.

345 Micklethwait \& Wooldridge, The Company: A Short History of a Revolutionary Idea, supra note 27, at 164. 
and non-fiscal barriers like requiring special standards and licensing requirements, and all these barriers were considered a golden key that would support the economy.

Meanwhile, the still liberalized environment in the UK was flying the free trade flag during the same period, encouraging more foreign corporations to invest and even incorporate in the UK, and that was not an exceptional characteristic about the UK; it is undoubtedly true that that is the result in any other remaining liberalized economy. ${ }^{346}$ Based on that, it has been reported that American corporations invaded the European markets, especially the UK, during the period from the late 19th century to the beginning of the 20th century and that led Austrian officials in 1897 to send letters to their counterparts in the other European countries, asking them to unite against what were named the "American invaders". 347

What brought that trend or form of relation between the state and the corporation to an end, after almost 50 years, was the introduction of the General Agreement on Tariffs and Trade (hereinafter GATT) ${ }^{348}$ While it was just a temporary agreement to put into action the proposed system of tariff reductions, it turned out to be a "framework for international coordination of trade policies." 349 One of the main reasons behind that movement for the GATT was that, by the end of World War I, most of the countries across the globe were playing the role of supporting their domestic corporations by adopting protectionist measures, and even the UK surrendered to that idea in $1932 .{ }^{350}$

In the same context, almost all countries circumvented the GATT and all the other movements that counterattacked their tendencies to control corporations by several actions; one of these actions was designing several exceptions that permitted additional protectionism measures, such as the antidumping system. ${ }^{351}$ It was even reported that the state tried to intensify

\footnotetext{
346 Maher M. Dabbah, Competition Law and Policy in the Middle East at 5 (Cambridge University Press. 2007).

347 Micklethwait \& Wooldridge, The Company: A Short History of a Revolutionary Idea, supra note 27, at 164.

348 General Agreement on Tariffs and Trade, Oct. 30, 1947.

349 J. M. Finger, The Origins and Evolution of ANTIDUmping Regulation at 24 (Country Economics Dept., World Bank. 1991).

350 Micklethwait \& Wooldridge, The Company: A Short History of a Revolutionary Idea, supra note 27, at 170.

351 For more comprehensive details about antidumping laws see generally Greg Mastel, Antidumping Laws and the U.S. Economy (M.E. Sharpe. 1998); J. M. Finger \& Nellie T. Artis, Antidumping: How it Works and Who Gets Hurt (University of Michigan Press. 1993).
} 
its control by introducing "industry-specific" regulations by the second half of the 20th century, and it was trying to drive all corporate goals to economic and social welfare ends. ${ }^{352}$

For instance, President Roosevelt ${ }^{353}$ himself said that "[Corporations] are indispensable instruments of our modern civilization; but I believe that they should be so supervised and so regulated that they shall act for the interests of the community as a whole." ${ }^{354}$ The state goal was a good one to defend but how to reach it was another issue, and it could be claimed that it was not yet well planned. Accordingly that form of the relation almost failed and led to the adoption again of some of the old liberalized approaches but possibly with a more liberalized essence, as will be shown in the following discussion.

\section{(f) Privatization and industry deregulation}

During the second half of the 20th century most economies were not flourishing across the globe due to high inflation rates, recession, and high unemployment rates. ${ }^{355}$ All these negative features of the economy were the main reasons behind pushing the state to adopt more liberalized measures toward the economy in general and the corporations specifically; one of these measures was "corporatization", which was changing the structure and the environment in the corporations owned by the government to resemble private management schemes. ${ }^{356}$

Those measure were followed by more serious steps, one of which was started by British Prime Minister Margaret Thatcher ${ }^{357}$ in 1982. It was the privatization trend or mania, i.e. governments all over the globe started to sell government-owned corporations to private parties. The British government privatized the North Sea oil and gas corporations and then it continued and privatized British Airways, electricity, gas,

352 Robert B. Horwitz, Understanding Deregulation, 15 TheORY AND SocIETy 139 , at $142-143$ (1986).

353 Theodore Roosevelt (October 27, 1858-January 6, 1919) was the 26th president of the United States, and he was also an American author, historian, and politician.

354 Quoted in Micklethwait \& Wooldridge, The Company: A Short History of a Revolutionary Idea, supra note 27, 182.

355 Bakan, The Corporation: The Pathological Pursuit of Profit and Power, supra note 126 , at 21.

356 Micklethwait \& Wooldridge, The Company: A Short History of a Revolutionary Idea, supra note 27, at 126.

357 Margaret Hilda Thatcher (October 13, 1925-April 8, 2013) was the leader of the Conservative Party in the UK from 1975 to 1990 and she was also the prime minister of the UK from 1979 to 1990. 
steel, telecommunications, water, and within ten years two-thirds of stateowned corporations were sold. ${ }^{358}$

Meanwhile it was also reported that not all industries had gone through the said privatization scheme, but the state reserved some industries to itself. ${ }^{359}$ For example, despite the fact that it is permitted under the law in Egypt for a privately held corporation to own and operate power plants, the right to do so was not granted to anyone until the end of the 20th century. ${ }^{360}$ But generally speaking, by 1992 the privatization mania was spreading everywhere across the European countries, and all the state-owned giant corporation like Deutsche Telekom, ENI, Elf, Renault, and Volkswagen were either entirely or somewhat privatized. The same was also the trend in Southeast Asia and Latin America, and it was also reported that Russian President Boris Yeltsin ${ }^{361}$ started a huge privatization plan through the same pattern i.e. "corporatization" then privatization. ${ }^{362}$

Some may claim that privatization has nothing to do with the relation between the state and private corporations. However, it has been stated that there was a direct proportionate relation between privatization as a trend and introducing regulatory measures to control the corporations that were previously owned by the state, and that was reported across the globe and in many industries, for example the telecommunications industry and the power industry. ${ }^{363}$ In addition to that, it was even claimed that privatization mania was one of the main factors that forced the state to take more radical moves in the future, namely "deregulation."364

During the same period, i.e. the 1980s-1990s, the position in the US was totally different due to the different structure of the corporate environment. The US was already taking the next step, i.e. industry deregulation, and to be more precise US President Jimmy Carter started by deregulating the airline industry and that was followed by the railroads and trucks and

358 Micklethwait \& Wooldridge, The Company: A Short History of a Revolutionary Idea, supra note 27, at 126.

359 Stanley Foster Reed, et al., The Art of M\&A at 103 (4th ed., McGrawHill. 2007).

360 For more details see infra p.171.

361 Boris Nikolayevich Yeltsin (February 1, 1931-April 23, 2007) was a Russian politician and the first president of the Russian Federation from 1991 to 1999.

362 Micklethwait \& Wooldridge, The Company: A Short History of a Revolutionary Idea, supra note 27, at 127.

363 David Levi-Faur, The Global Diffusion of Regulatory Capitalism, 598 Annals of the American Academy of Political and Social Science 12, at 18 (2005).

364 Micklethwait \& Wooldridge, The Company: A Short History of a Revolutionary Idea, supra note 27, at 125. 
then telecommunications. Ironically, though, it has been claimed that even after the deregulation started, the state bureaucratic representatives in the US and across the EU were ready to hold up that liberal approach by finding some roles for themselves in the new form of relation between the state and the corporation. ${ }^{365}$

The deregulation liberal approach was expanded in the US to an unprecedented extent during the term of President George W. Bush, ${ }^{366}$ who was the first American president to hold the degree of Master of Business Administration. He was planning to deregulate the power industry, but unfortunately by the end of 2001 a broad stream of accounting scandals started, with the collapse of a giant power corporation, Enron, in just a few weeks, followed by the collapse of the giant telecommunications corporation WorldCom, and also most of the related accounting firms like Arthur Andersen. ${ }^{367}$ Actually delving into the details of these accounting scandals is beyond the scope of this book, ${ }^{368}$ but it should be noted that the inevitable results of these scandals was that the state started to intervene again, this time by introducing bundles of laws and regulations like the Sarbanes Oxley Act $^{369}$ in order to regain power over the corporations. ${ }^{370}$

Undoubtedly true, the industry deregulation trend was running in parallel with other state control measures taken toward corporations. For instance, several controlling measures were introduced like the Sarbanes Oxley Act and many other protectionism measures like controlling the foreign investments in the US by the Foreign Investment and National Security Act, ${ }^{371}$ which will be considered in detail in the later discussion of the impediments to cross-border mergers. ${ }^{372}$

365 Micklethwait \& Wooldridge, The Company: A Short History of a Revolutionary Idea, supra note 27, at 128.

366 George Walker Bush (born July 6, 1946) is an American businessman and politician (Republican), and he was the 43rd president of the United States from 2001 to 2009.

367 Micklethwait \& Wooldridge, The Company: A Short History of a Revolutionary Idea, supra note 27, at 153.

368 For more information about the Enron scandal see the documentary Enron: The Smartest Guys in the Room (Magnolia Pictures. 2005).

369 Sarbanes Oxley Act of 2002 (Pub.L. 107-204, 116 Stat. 745, enacted July 30, 2002).

370 Micklethwait \& Wooldridge, The Company: A Short History of a Revolutionary Idea, supra note 27, at 151.

371 Foreign Investment and National Security Act of 2007 (Pub.L. 110-49, 121

Stat. 246, enacted July 26, 2007).

372 See infra p.181. 
Along the same lines, it was maintained that the deregulation was offset by the political efforts exerted toward the old goal of driving all corporate goals to economic and social welfare ends. ${ }^{373}$ Most importantly, it has been claimed that the deregulation was just a deregulation of the markets, while the relation between the state and corporations started to take a new route in the opposite direction, which is overregulation and that was even more complicated than at any time before. ${ }^{374}$ Thus scrutinizing all the details of those current complicated and overregulation trends is unmanageable and beyond the scope of this book, and it will be limited to scrutinizing only the regulation of the merger industry, and to be more precise the rules that control mergers.

\section{(g) Corporation counterattacking state}

It is undoubtedly true that the corporation throughout history was not an innocent, powerless, or idle party in that relation i.e. the relation with the state. The corporation threatened to counterattack the state whenever it had to do so, mainly in the situation where the state was using its powers to over-control the development or the expansion of the corporation. It is noteworthy that corporation threats were not a new phenomenon; they were as old as introducing state measures to control corporations. This discussion will include four straightforward examples of a clear threat to the economy of the state by corporations.

The first example is based on what was previously discussed concerning minorities throughout history, whether due to race, nationality, or religion, who united and formed groups to feel safer, to share the benefits among the group, and to support each other. These groups did not hesitate to threaten the state and to withdraw their investments, even just for personal reasons not related to state over-control. For instance, it has been reported that in 1723 the Russian government refusal of an Indian widow's request to be burned along with her dead husband led to a real threat from all Indians to take their investments and leave Moscow. The Russian government bowed in the end and it should be noted that that incident was not the only one; the same incident was reported again in $1767 . .^{375}$

The second example was reported in the 1920s, when the American

373 Horwitz, Theory AND Society, supra note 352, at 142-143; Micklethwait \& Wooldridge, The Company: A Short History of a Revolutionary Idea, supra note 27 , at $149-150$.

374 Micklethwait \& Wooldridge, The Company: A Short History of a Revolutionary Idea, supra note 27, at 190.

375 BraUdel, The Wheels of Commerce, supra note 45, at 153, 165. 
General Motors Corporation acquired the British Vauxhall Corporation and the German Opel Corporation. The transaction was mainly structured to bypass tariffs imposed during that period, and it has been reported that its Chief Executive Officer (hereinafter CEO) Alfred Pritchard Sloan announced it clearly when he said that "[w]e had to work out a special form of organization that would be suitable overseas." ${ }^{376}$ That example clearly demonstrates that whenever the state came up with a new policy tool such as tariffs, corporations would emigrate to a friendlier environment.

The third example was simply a dream of the CEO of Dow Chemical Corporation in 1970. He revealed this by saying "I have long dreamed of buying an island owned by no nation and of establishing the world head quarters of the Dow company on the truly neutral ground of such an island, beholden to no nation or society." 377 The dream of the Dow Chemical Corporation was similar to some extent to the second example, but it was a more far-reaching one: He dreamed of owning the environment instead of just living in a friendly one.

The fourth example is the telecommunications corporations in Cuba; in that example the corporations were actually controlling the state and its decisions. ${ }^{378}$ Those examples are not the full list, and it could easily be claimed that a lot of examples had already appeared and will continue to appear every now and then. Those examples were mainly due to the fact that the state approach toward corporations is not always the same all over the globe, and whenever one state overuses its power to control, the corporation threatens to leave that state by making use of opportunities offered by another state that underuses its powers.

However, others argued that despite the fact that the approach of almost all the states was and will be more complicated by time, that it is not always in the same direction. The approaches are always fluctuating between the two extremes, deregulation and overregulation, and will last as trends or "cyclical" patterns. An example is when the state sometimes uses the antitrust laws as a tool to control a corporation that already operates in a deregulated industry, ${ }^{379}$ and that is supporting the very claim that

\footnotetext{
376 Micklethwait \& Wooldridge, The Company: A Short History of a Revolutionary Idea, supra note 27, at 170.

377 Leslie Sklair, The Transnational Capitalist Class at 12 (Blackwell. 2001).

378 For more details on how the telecommunications corporations controlled Cuba see generally T. J. English, et al., Havana Nocturne How the MoB Owned CubA-AND then Lost It to the Revolution (Playaway Digital Audio: [manufactured and distributed by] Findaway World, LLC. 2009).

379 Gevurtz, Washington LaW Review, supra note 128, at 487-489.
} 
the state was deregulating the markets, not deregulating the corporation itself.

Finally, it is clear from the previous discussions that the corporations used the state to develop themselves at first, but that turned out through the history to became an opportunity for the state to attack back by control and make use of the corporations. Moreover throughout history the state did not follow a single approach, it rather followed many, while struggling to manage its goals. ${ }^{380}$ Some of these approaches were welcomed and sometimes initiated by the corporations themselves, while others were counterattacked. To sum up, the relation between the state and corporations is a battle of interests that will never come to an end, and sometimes they cease fire in order to take time to prepare and re-attack, or even due to the convergence of their interests. That was perfectly summarized in the fact that the corporation was born under a "franchise" from the society represented by the state, and the corporation will always need to keep that "franchise," but the state will never give it up unconditionally. ${ }^{381}$

\section{DEMYSTIFICATION OF MERGERS}

The following discussions will first include the technical definition of the term merger, and then it will include several classifications of the different types of mergers, and distinctions between mergers and some other growth alternatives. Secondly, it will include an overview of the merger dynamics; how the transaction starts with preparation and screening and then moves through various steps, and how these steps conclude with the final step, i.e. closing the transaction. The discussion will also include an overview of some of the post-closing issues, as follows.

\section{Definition of Mergers}

Although the corporation started as an embryo of the state and developed throughout history to help the state in fulfilling its obligations or responsibilities toward its citizens for a well-functioning society, there were always various breakthroughs during this very long journey. The scaling through mergers, and even more through mergers between competitors, was one of

380 BRAUDEL, The Wheels of Commerce, supra note 45, at 515.

381 Micklethwait \& Wooldridge, The Company: A Short History of a Revolutionary Idea, supra note 27, at 182. 
these exceptional breakthroughs. ${ }^{382}$ Moreover, as the previous discussion of merger waves and their global expansion showed, mergers were to a great extent popular and old, and that was relatively sufficient to have the same solid definition in most of the legal systems across the globe. Meanwhile, as it was previously noted that the term merger is used in these discussions to indicate mergers, consolidations, and acquisitions, it should be noted that there is a distinction between all these terms as follows. ${ }^{383}$

Acquisitions were defined as the process of purchasing all or part of the shares of a corporation (hereinafter target) by another corporation (hereinafter acquirer), and by that process the target will continue to exist as well as the acquirer, but all assets and liabilities of the target that resemble the purchased shares will be owned by the acquirer. On the other hand, a merger was simply defined as the process of combining two or more corporations to become only one corporation; one of these corporations will survive but all the others will cease to exist. Meanwhile, consolidation is almost like a merger but in consolidation all the corporations cease to exist, and all are combined under one new corporation. ${ }^{384}$ Figures $1.8-1.10$ will simply illustrate the differences to avoid any confusion.

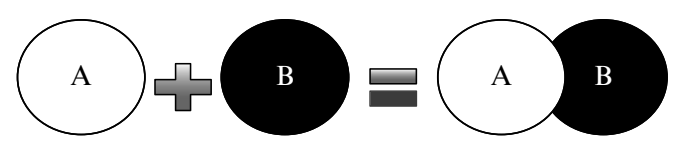

Figure 1.8 Acquisition

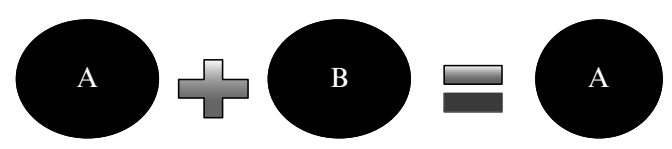

Figure 1.9 Merger

\footnotetext{
382 Stigler, The American Economic Review, supra note 258, at 23.

383 It should be noted here again that for the rest of the discussion, whenever possible and appropriate, the term "merger" will be used to indicate all these terms.

384 AndreW J. Sherman, MERgers \& ACQuisitions from A to Z at 11 (2nd ed., AMACOM. 2006); REED, et al., The Art of M\&A, supra note 359, at 4; RICHARD A. Roberts \& Barry S. Mann, Business LaW and the Regulation of Business at 774-775 (10th ed., South-Western Cengage Learning. 2011); DePAMPHILIS, Mergers and Acquisitions Basics: All You Need to Know, supra note 238, at 13-14.
} 


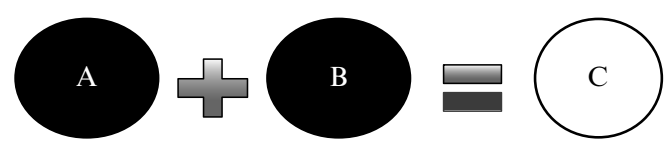

Figure 1.10 Consolidation

However, the everyday transactions are not as simple and straightforward as these definitions or Figures 1.8-1.10 may indicate, and actually different terms are given where there is a combination of these processes in the same transaction. To illustrate, acquirer A may use its subsidiary $\mathrm{C}$ to purchase target B in a process known as "subsidiary merger," by which both $A$ and $B$ will survive, but $B$ will be a subsidiary of $A$. If $B$ then merged again with $A$, and $B$ ceased to exist, the process will be known as "reverse subsidiary merger." In other cases different terms are also used to distinguish between the friendly transactions done by the will of all the parties from unfriendly forced transactions, "takeover," and "hostile takeover," 385 and even more terms are used for other complicated transactions, as will be scrutinized in detail in the following discussions.

The most complicated transactions are cross-border mergers, and while they constitute less than 50 percent of the total announced mergers across the globe, ${ }^{386}$ it is considered a very significant category of transactions in the world economy, because it constitutes more than 50 percent of FDI. ${ }^{387}$ To illustrate more about how huge those kinds of transactions are, and of the great value to the world economy, on April 12, 2000 the European Commission (hereinafter EC) announced that it would not block the cross-border merger transaction between the British corporation Vodafone Airtouch and the German corporation Mannesmann, the value of which was approximately 180 billion US dollars. ${ }^{388}$ In that context, it was also reported that the volume of transactions done in the Middle East region, as the fourth active acquirer in the world, exceeded 106 billion US dollars in 2007.389

Meanwhile, it is noteworthy that due to the fact that corporations nowadays have become multinational, with operations in many countries,

385 Gaughan, Mergers, Acquisitions, and Corporate Restructurings, supra note 237 , at 7 .

386 Mohammed, A Story of Two Halves, supra note 2, at 11, 15; Hopkins, JOURNAL OF INTERNATIONAL MANAGEMENT, supra note 2, at 208-209.

387 Neary, The Review of Economic Studies, supra note 3, at 1229.

388 Commission Notice, 2000 O.J. C 141/07.

389 Mohammed, A Story of Two Halves, supra note 2, at 15. 
and added to the fact that there are some issues related to defining the corporate nationality, sometimes it is not an easy task to distinguish between cross-border mergers and "semi-domestic" merger transactions. Moreover, there is no clear definition of what should be a pure domestic transaction and what is not. For instance, it has been reported that the merger transaction between the American corporation Wal-Mart and the Puerto Rican corporation Supermercados Amigo was considered a "semidomestic" transaction because Puerto Rico is a "partially autonomous US commonwealth." 390

Finally, as was previously noted, during the last decade of the 20th century there was an important regularly active category of players in the field of cross-border mergers. They were not new players but they steadily started to become key players; they were the SWF. In that context, it has been reported that in 2007 the total value of cross-border merger transactions exceeded 48.5 billion US dollars. ${ }^{391}$ Overall SWF investments across the globe were estimated at 6.5 trillion US dollars by the end of May 2014, and that increase is expected to continue. ${ }^{392}$

\section{Merger Types and Classifications}

The following discussion will show that merger types and classifications are vast, and that it mainly depends on perspective. First, the discussion will include a classification of mergers from an economic perspective; according to this classification mergers will be categorized as horizontal, vertical, and conglomerate mergers. Meanwhile, the second part of the discussion will include a classification of mergers from a structural and procedural perspective, whereby mergers can be classified into direct, triangular, reverse, and many other types that have more complicated structures.

A third classification will be from a financial perspective. The discussion will show how mergers are classified according to the financial schemes that are used to finance the transaction, and that depends on whether it was through debt or equity. According to that classification the merger transaction could be done through many debt structures, such

390 Daniel A. Crane, Anti-Competitive Behavior and International Law: Substance, Procedure, and Institutions in the International Harmonization of Competition Policy, 10 Chicago Journal of International Law 143, at 149 (2009); Eleanor M. Fox, An Anti-Monopoly Law for China: Scaling the Walls of Governments Restraints, 75 Antitrust LAW Journal 173, at 183-184 (2008).

391 Kalsi, Sovereign Wealth Funds, supra note 6, at 16-17.

392 For more details and a full profile of all of the SWF across the globe see http://www.swfinstitute.org (last visited December 1, 2017). 
as LBO, Management Buyout (hereinafter MBO), or an Employee Stock Ownership Plan (hereinafter ESOP). Moreover, the merger transaction could also be done in cash, stocks, or assets exchange, and also through a mixture of any of these financing tools.

In the same context, it should be noted that mergers are generally considered as corporate restructuring transactions, whether for the purpose of growth or for any other purpose, and could also be distinguished from other restructuring transactions by the fact that mergers are classified as an operational restructuring process, and not as a financial restructuring process. Meanwhile, there are some other trends and forms of corporate operational restructuring transactions like spin-off, carve-out, roll-up, etc., ${ }^{393}$ thus the fourth part of the following discussion will address some of these trends and forms of transactions. Finally, the discussion will close by addressing some other transactions, which are usually used by corporations for the purpose of growth, as an alternative to mergers.

As was previously mentioned, mergers could also be classified according to the nature of the approval of the transaction by the target's management and shareholders, i.e. friendly and hostile takeovers. Meanwhile, as it was mentioned in the introduction that hostile takeover transactions are governed by specific rules that are not applied to friendly mergers, and the discussions in this book are limited to friendly mergers, the following sections will not include such category of classification. In the same context, and for the same reason, the following discussion will not include the classification of mergers from a tax perspective i.e. taxable and non-taxable mergers.

\section{(a) Economic classifications}

From an economic perspective, scholars usually divide mergers into three categories: horizontal, vertical, and conglomerate mergers. ${ }^{394}$ As was previously mentioned during the discussion of merger waves, ${ }^{395}$ a horizontal merger is simply a merger between two or more corporations that are all operating at the same level in the same or related industries, for instance the merger between two corporations that are operating at the level of

393 DePamphilis, Mergers and Acquisitions Basics: All You Need to Know, supra note 238 , at 17.

394 Stephen A. Ross, et al., Corporate Finance at 818 (6th ed., McGraw-Hill. 2002); Koutsoudakis, Dayton LAw Review, supra note 198, at 227-228; DePamphilis, Mergers and Acquisitions Basics: All You Need to Know, supra note 238, at 14; WeSTON \& WeAVER, Mergers and Acquisitions, supra note 239, at 12.

395 See supra p.43. 
manufacturer in the computer industry, like, for example, the merger that was concluded between Hewlett Packard and Compaq. ${ }^{396}$

Other examples, in the oil and gas industry, are the mergers that were concluded between two giant corporations Exxon and Mobil, and between Chevron and Texaco. Moreover, as an example from what is known as the fast-moving consumer goods industry, the merger between Procter \& Gamble and Gillette was also classified as a horizontal merger. ${ }^{397}$ An example from the industry of technology and social media networking is the merger between Facebook and Instagram, which was a horizontal merger, ${ }^{398}$ and even more recently, the merger between Facebook and WhatsApp. 399

It should be noted that horizontal mergers are classified into two subcategories, namely market-extension merger and product-extension merger; the merger would be classified as a market extension when the merging corporations are operating in the same industry but in different markets, i.e. not in the same geographic area, and in that type of merger the corporation will get the opportunity to access all these different markets. A horizontal merger is known as a product-extension horizontal merger if the merging corporations are operating in related industries, where the merging corporations will get the opportunity to share resources and operations, and sometimes bundling. ${ }^{400}$

On the other hand, a vertical merger, as was also previously mentioned during the discussions of merger waves, ${ }^{401}$ could simply be defined as a merger between two or more corporations where some or all of them are not operating at the same level in the same or related industries. A good example is a merger between two corporations, one of which is operating at the manufacturing level and the other at the distribution level. The

396 Marco Becht, et al., Chapter 12 Corporate Law and Governance, in Handbook of Law and Economics at 852 (A. M. Polinsky \& S. Shavell eds. 2007).

397 DePamphilis, Mergers and Acquisitions Basics: All You Need to Know, supra note 238 , at 14 .

398 Tomio Geron, Facebook Officially Closes Instagram Deal, Forbes magazine, September 6, 2012 https:/www.forbes.com/sites/tomiogeron/2012/09/06/ facebook-officially-closes-instagram-deal (last visited December 1, 2017).

399 Tim Bradshaw, As it happened: Facebook's \$19bn WhatsApp deal, Financial Times, February 19, 2014, http://blogs.ft.com/tech-blog/liveblogs/fbwhatsapp-liveblog (last visited December 1, 2017).

400 João D. Cicarini Jr., Valuation for M\&A Purposes: An Analysis of its Importance to Present a Fair Value of a Company and its Implications for the $M \& A$ and Post-integration Process (Aalborg University. 2009).

$401 \quad$ See supra p.43. 
merger transaction between Time Warner and Turner is an example of a merger transaction concluded between a giant broadcasting and cable operator corporation and a media production corporation..$^{402}$

In addition to that, vertical mergers are also classified into two subcategories as forward vertical mergers and backward vertical mergers; the transaction will be considered as a forward transaction if the acquirer purchased a target that is operating at a level before the level that the acquirer is operating and vice versa. To elaborate more, an example of a forward vertical merger is the merger between Boise Cascade as an acquirer and OfficeMax as a target, where the acquirer was a wood products supplier and the target was a distributer of some of these products. ${ }^{403}$ An example of a backward vertical merger is the merger between Walt Disney as an acquirer and Pixar as a target where the studio entertainment segment of Walt Disney Company distributed animated and featured movies and Pixar was a creator of such movies. ${ }^{404}$

Meanwhile, conglomerate merger is simply the merger between two or more corporations where some or all of them are operating in different or unrelated industries, in other words it is neither a horizontal nor a vertical merger. ${ }^{405}$ This would be a merger between two corporations, one of which is operating at any level in certain industry and the other at the same or another level in another unrelated industry. An example of a conglomerate merger was the merger concluded between Phillip Morris, which operates at the production level in the tobacco industry, and Kraft General Foods, which operates also at the production level, but in the grocery manufacturing and processing industry. ${ }^{406}$

402 Mergers and Competition in the Telecommunications Industry Hearing before the Committee on the Judiciary, United States Senate, One Hundred Fourth Congress, Second Session September 11, 1996 at 84-85 (U.S. G.P.O. 1997).

403 DePamphilis, Mergers and Acquisitions Basics: All You Need to Know, supra note 238 , at 15 .

404 Jérôme Barthélemy, The Disney-Pixar Relationship Dynamics: Lessons for Outsourcing vs. Vertical Integration, 40 Organizational Dynamics 43 (2011).

405 Koutsoudakis, DAYTON LAW ReVIEW, supra note 198, at 228; WeSTON \& WEAVER, Mergers and Acquisitions, supra note 239, at 12; Cicarini Jr., Valuation for M\&A Purposes: An Analysis of its Importance to Present a Fair Value of a Company and its Implications for the M\&A and Post-integration Process, supra note 400 , at 18 .

406 Dennis C. Mueller, Efficiency Versus Market Power Through Mergers, in The International Handbook of Competition at 65 (Manfred Neumann \& Jürgen Weigand eds. 2004). 


\section{(b) Structural and procedural classifications}

A merger could also be classified according to the structure and procedures adopted to go through the transaction and in that regard there are many classifications. Basically mergers could be classified according to how the transaction was done i.e. whether it was directly between the merging corporations or indirectly through a subsidiary owned by any of them. In that context, mergers could be classified into two categories: direct and triangular mergers. A direct merger transaction is simply concluded between the merging corporations, whereas in a triangular merger a subsidiary owned by one of the merging corporations will go through the transactions instead of its parent corporation. ${ }^{407}$

There are many advantages to the triangular merger transaction: (1) the transaction should be approved by the shareholders of the subsidiary, i.e. the acquiring parent corporation not the shareholders of the acquiring parent corporation itself, and that might circumvent any requirement imposed in that regard; (2) the acquirer parent corporation will not be liable for the target liabilities and the liability will be limited only to the subsidiary; and (3) the registration fees of the target assets as well as taxes might be avoided in some legal systems. ${ }^{408}$

In the same context, it is noteworthy that there are two subcategories of triangular mergers; if the target is merged into the subsidiary it will be known as a forward triangular merger, and if the subsidiary is merged into the target the transaction will be known as reverse triangular merger. ${ }^{409}$ It should be noted that in triangular reverse mergers there are some additional advantages, for example the target might keep holding non-assignable agreements and any other regulatory licenses, unless otherwise clearly required by law. ${ }^{410}$

Mergers could also be classified into two categories according to the structure of the merging corporations after the transaction: statutory mergers and subsidiary mergers. If the acquirer swallows the target in the transaction and all of its liabilities and assets, and the target ceases to exist, the transaction will be classified as a statutory merger. On the other hand, if the target survives after the transaction as a subsidiary of the acquirer, the transaction will be classified as a subsidiary merger. ${ }^{411}$

407 Edwin L. Miller, Mergers and Acquisitions: A SteP-By-Step Legal and Practical Guide at 84 (Wiley. 2008).

408 Weston \& WeAVER, Mergers and Acquisitions, supra note 239, at 15-16.

409 Miller, Mergers and Acquisitions: A Step-by-Step Legal and Practical Guide, supra note 407, at 84.

410 WeSTON \& WeAVER, Mergers and Acquisitions, supra note 239, at 17-18.

411 DePamphiLis, Mergers and Acquisitions Basics: All You Need to Know, supra note 238 , at $13-14$. 
Mergers could also be classified according to the procedures or the steps taken to finalize the transaction into two categories, according to whether the transaction is finalized in just one step or in a series of steps. ${ }^{412}$ In that context, the typical first category is the classic merger transaction in which the transaction is finalized in one step. A second category is one in which the transaction is done in two steps: The first step is acquiring a significant or controlling share of the target and that is almost always done through a tender offer; the second step is merging the whole target into the acquirer or merging the acquirer itself into the target, which is known as "reverse merger," and that second step is taken in most cases through a transaction known as a "squeeze out" because in that transaction the minority shareholders will be forced to go through the merger. 413

It is noteworthy in that context that a privately held corporation, i.e. a corporation that does not have its shares as tradable in the stock exchange, may use the "reverse merger" transaction to circumvent stock market regulations or requirements of going public, i.e. being listed on the stock exchange and having its shares become tradable. ${ }^{414}$ In other words, a private corporation may acquire a publicly traded corporation to work as a "shell corporation", and then the acquirer merges into this shell corporation and becomes a publicly tradable corporation by the end of the transaction without satisfying any listing requirements.

\section{(c) Financial classifications}

As was previously mentioned, the merger transaction could be financed either through a debt or equity or even by a mixture of both, and if the transaction will be mainly financed through debt the merger will be known as an LBO. ${ }^{415}$ In a typical LBO transaction the acquirer is almost always a shell corporation with modest borrowing abilities, where a large percentage or even all the transaction is financed through debt, and both the target's

412 Sherman, Mergers \& Acquisitions from A to Z, supra note 384, at 117; REED, et al., The Art of M\&A, supra note 359, at 270-271.

413 For more details about the "squeeze out" transaction see MiLler, Mergers and Acquisitions: A Step-by-Step Legal and Practical Guide, supra note 407, at 100.

414 Gaughan, Mergers, Acquisitions, and Corporate Restructurings, supra note 237, at 17; Cicarini Jr., Valuation for M\&A Purposes: An Analysis of its Importance to Present a Fair Value of a Company and its Implications for the M\&A and Post-integration Process, supra note 400, at 19.

415 DePamphiLis, Mergers and Acquisitions Basics: All You Need to Know, supra note 238 , at $15-16$. 
assets and the expected returns or profits will serve as collateral for that debt. ${ }^{416}$

If the management of the target was the shareholders of the acquirer shell corporation, the transaction is known as an $\mathrm{MBO} \cdot{ }^{417}$ It should be noted here that most $\mathrm{MBO}$ transactions are used as a defensive tactic against hostile takeovers or at least making the shares of the target less attractive, which is known as "poison pills." 418 Moreover, both LBOs and MBOs are frequently used to restructure a publicly traded corporation to turn it into a private corporation so that its shares will no longer be tradable on the stock exchange. ${ }^{419}$

In some other cases the LBO merger transaction is reversed for the purpose of turning non-tradable shares of a corporation into publicly traded shares on the stock exchange, which is known as "Reverse LBO." 420 Unfortunately, bad management practices may lead the management team to be engaged in buying undervalued shares through an MBO transaction, and then reselling the shares back again through a Reverse LBO transaction, for an overvalued or even fair value, only to gain personal profits. ${ }^{421}$

There is another version of LBO transactions, which is the ESOP, where the employees' pension plan funds are used mainly to acquire the shares of their employer through the use of a shell corporation. That version of the LBO, i.e. ESOP, is generally used as a defensive tactic against hostile takeovers. ${ }^{422}$ Furthermore, ESOP has some other benefits, for instance it has been reported that ESOP has been widespread in the US since the 1920 s, and that was mainly for its tax benefits. ${ }^{423}$

416 Miller, Mergers and Acquisitions: A Step-by-Step Legal and Practical Guide, supra note 407, at 295.

417 Sherman, Mergers \& Acquisitions from A to Z, supra note 384, at 123; Weston \& Weaver, Mergers and Acquisitions, supra note 239, at 183; Gaughan, Mergers, Acquisitions, and Corporate Restructurings, supra note 237, at 11.

418 Ross, et al., Corporate Finance, supra note 394, at 841; For more details about defensive tools against hostile takeover i.e. poison pills, see ROBERT WINTER, et al., State Takeover Statutes and Poison Pills (Prentice Hall Law and Business. 1988).

419 Gaughan, Mergers, Acquisitions, and Corporate Restructurings, supra note 237, at 11; DePamphilis, Mergers and Acquisitions Basics: All You Need to Know, supra note 238 , at 15-16.

420 Gaughan, Mergers, Acquisitions, and Corporate Restructurings, supra note 237 , at 315 .

421 Leslie Wayne, Reverse LBOs Bring Riches, New York Times, April 23, 1987.

422 WeSTON \& WEAVER, Mergers and Acquisitions, supra note 239, at 191-193.

423 Gaughan, Mergers, Acquisitions, and Corporate Restructurings, supra note 237 , at 370 . For more details about the tax benefits in the US see id. at 379-380. 
However, ESOP also has some other disadvantages, or at least has phony benefits that are not usually realized to the expected level. For instance, it was maintained that the corporation will realize extra gains or profits because the employees themselves will make extra efforts to serve their own interests, but in fact it has been reported that no such differences were found between ESOP and other LBO or mergers transactions in that regard. ${ }^{424}$ Moreover, proper financial analysis of the actual costs of ESOP transactions proved that one of its disadvantages is that it is considered as an equity dilution and that will inevitably lead to loss of control over the corporate shares. ${ }^{425}$

It is undoubtedly true that all these classifications from the financial perspective have important implications for the transaction and whether it might be taxable or not. ${ }^{426}$ Therefore, merger transactions could also be classified into three main categories: taxable transactions, partial tax-free transactions, and tax-free transactions, ${ }^{427}$ and that will be further scrutinized during the discussions of structuring the transaction in the merger dynamics. ${ }^{428}$ Meanwhile, it is noteworthy that the tax-free merger transaction is not absolutely free, and to be more precise it could be considered a deferred taxable transaction because the shareholders will defer the tax payment until entering into a later taxable transaction, but in the merger industry that is known as a tax-free merger transaction. ${ }^{429}$

In the same context, as was previously mentioned, the merger transaction could be financed through one or more of these four financing schemes, accordingly the merger transactions could also be classified into an additional four categories: the first category is cash-only transactions; the second is stock-only transactions, which are known as stock-for-stock transactions; the third is what are known as stockfor-assets transactions; and finally the fourth category is a mixture of

424 U.S. General Accounting Office, Employment Stock Ownership Effects: Little Evidence of Effects on Corporate Performance, Report to the Committee on Finance, U.S. Senate (U.S. G.P.O. 1987).

425 Gaughan, Mergers, Acquisitions, and Corporate Restructurings, supra note 237 , at $381-382$.

426 For more details about the general idea of taxes and their effect on merger transactions see JosePh P. Driscoll, TAXABle ACQUisitions AND THEIR EFFECT ON Seller AND Purchaser, at 81-103 (Bobbs-Merrill. 1956).

427 Sherman, Mergers \& Acquisitions from A to Z, supra note 384, at 113.

428 See infra p.107.

429 ReED, et al., The Art of M\&A, supra note 359, at 321; Sharon Stern Gerstman, et al., International Tax Law, 43 INTERNATIONAL LAWYer 759, at 769 (2009). 
these categories or schemes. In that regard, and according to the US tax regime, it should be noted that only two of these categories are considered tax-free transactions: (1) stock-for-stock mergers and (2) stock-for-assets mergers. ${ }^{430}$

In that tax context, it should be distinguished that there are some merger structures that were specially tailored to avoid taxation in cross-border merger transactions. These structures are as follows: (1) "Dividend Access Share Structure," in which the transaction will involve linking the value of the shares of the merging corporation without actual exchange of the shares between the parties; (2) "Exchangeable Share Structure," in which the transaction is the same as the dividend access share structure but the target will issue exchangeable shares to be exchanged on demand; and (3) "Equalization Structure," in which the transaction will also be the same as the dividend access share structure but the merging corporations will jointly control the merging corporations. $^{431}$

Finally, the merger transaction could be classified into two other categories, according to the percentage of the shares acquired by the acquirer, where the acquirer may acquire only a controlling share of the target, and in that case the acquirer will be known as a holding corporation. On the other hand, the acquirer may acquire all the shares of the target, and in that case the target will be known as a wholly owned subsidiary. It should be noted that to call an acquirer a holding corporation depends mainly on the percentage of acquired shares, and usually a certain threshold is required under the various legal systems. ${ }^{432}$

\section{(d) Other restructuring trends and forms}

There are various trends and forms of corporate restructuring transactions that are closely connected to mergers. These are mainly spin-offs, carve-outs, roll-ups, and tracking stocks. This section will address each of these trends or form of transactions in turn. Generally speaking, spin-offs and carve-outs are classified as divestiture transactions, and a divestiture transaction is simply a transaction by which a corporation decides whether

430 Sherman, Mergers \& Acquisitions from A to Z, supra note 384, at 109, 115; REED, et al., The Art of M\&A, supra note 359, at 322.

431 For more details about these structures see Richard Godden, et al., Cross Border Deals: Myth and Reality, PLI's Annual Institute on Securities REGULATION IN EUROPE 1121 at 1002-1017 (2001).

432 For more details about the advantages and disadvantages of the holding corporation structure see GaUghan, Mergers, Acquisitions, and Corporate Restructurings, supra note 237, at 18-19. 
to split a part or a whole of one of its owned subsidiaries, or a business unit, and sometime only certain assets. ${ }^{433}$

In fact a corporation might decide to go through divestiture due to either the poor performance of a subsidiary or business unit, or simply as a step to accomplish a new plan or strategy to be more focused on certain type of operations, or even sometimes to serve other downsizing purposes. ${ }^{434}$ However, in specific circumstances, a corporation may be obligated to go through an involuntary divestiture transaction, as will be scrutinized later in detail in the discussion about merger control.

The carve-out transaction is a typical divestiture transaction where the divested unit will be offered for sale to a third party i.e. another corporation or even to the public on the stock exchange. ${ }^{435}$ On the other hand spin-off, also a typical divestiture transaction, differs from the carve-out because the divested unit will remain owned by the shareholders of the corporation and will not be offered to a third party, and that unit will take the form of a new corporation that operates independently, away from the parent corporation. ${ }^{436}$

One more difference between both these forms is that the spin-off is always a free transaction, while carve-out might be taxable in some taxation systems. ${ }^{437}$ In that context, it has been reported that because of the exemption from taxation of spin-off transactions, some corporations deceptively use the spin-off form of transactions to evade taxes by hiding profits in the new unit or even use it the other way to hide losses in it, and that trend was reported to be widespread throughout the US during the 1990s. ${ }^{438}$

On the other hand the roll-up transaction is a kind of strategy adopted by an acquirer which is always a holding corporation. Through that strategy the acquirer will acquire many targets operating in a certain industry or a geographic region, and that could be done through a horizontal,

433 Sherman, Mergers \& Acquisitions from A to Z, supra note 384, at 122-123.

434 Gaughan, Mergers, Acquisitions, and Corporate Restructurings, supra note 237, at 11; Weston \& WeAVER, Mergers and Acquisitions, supra note 239, at 179.

435 Gaughan, Mergers, Acquisitions, and Corporate Restructurings, supra note 237, at 12; WeSTON \& WeAVER, Mergers and Acquisitions, supra note 239, at 180; DePamphilis, Mergers and Acquisitions Basics: All You Need to Know, supra note 238 , at $15-16$.

436 For more details see generally Alexandra R. Lajoux And H. Peter Nesvold, The Art of M\&A Structuring: Techniques for Mitigating FinANCIAL, TAX, AND LEGAL RisK (McGraw-Hill 2004).

437 ReED, et al., The Art of M\&A, supra note 359, at 337.

438 Sherman, Mergers \& Acquisitions from A to Z, supra note 384, at $122-123$. 
vertical, or even conglomerate transaction, and it was reported that the roll-up trend was widespread in the US in the 1990s. ${ }^{439}$ Meanwhile, tracking stocks are those types of stocks or shares that are issued and acquired by an acquirer who is interested in specific types of operation within a certain corporation and not in all its business, or even in a specific highgrowth division of the corporation. ${ }^{440}$

\section{(e) Distinction between mergers and other growth alternatives}

Generally speaking, corporations might make use of their own resources to grow internally, i.e. to maximize shareholder value as an ultimate measure of the corporation's success. ${ }^{41}$ That could be accomplished by opening new sales channels, hiring more sales staff, or developing new products, etc., and it might opt for external growth options like mergers or some other merger alternatives. Those alternatives are mainly JV, strategic alliance, franchising, licensing, exclusive agreements, and minority investments. ${ }^{442}$

Due to the close connections between all these external growth alternatives, this discussion will be an overview of each of them to draw a clear distinction between them all. The discussion will start with the growth alternative that gives the most controlling power, which is minority investments, followed by JV, then franchising, and then licensing and exclusive agreements, until the least controlling power-giving growth alternative, which is the strategic alliance option.

The minority investments option is the closest growth alternative to merger $^{443}$ because a corporation or an investor wants to maximize the shareholder value through the acquisition of a minority controlling share, in other words acquiring less than 51 percent of the target's voting shares. ${ }^{44}$ The growth alternative has many advantages, for instance the transaction might easily be done without any consent or prerequisite approvals, and in addition to that the acquirer could be passive and not bear any management obligations. However at the same time the acquired shares might have a significant voting power and the acquirer could

\footnotetext{
439 Sherman, Mergers \& Acquisitions from A to Z, supra note 384, at 124.

440 WESTON \& WEAVER, Mergers and Acquisitions, supra note 239, at 181.

441 DePamphilis, Mergers and Acquisitions Basics: All You Need to Know, supra note 238 , at 18 .

442 Sherman, Mergers \& Acquisitions from A to Z, supra note 384, at 10; Weston \& Weaver, Mergers and Acquisitions, supra note 239, at 122-123.

443 DePamphilis, Mergers and Acquisitions Basics: All You Need to Know, supra note 238 , at 18 .

444 Ross, et al., Corporate Finance, supra note 394, at 817-818.
} 
exercise control over the target. ${ }^{445}$ It should be noted here that SWFs are the most active players in the field, for instance it has been reported that the Qatar Investment Authority, which runs the State of Qatar's SWF, is typically opting for that growth alternative. ${ }^{446}$

On the other hand, in a typical JV two or more corporations enter into an agreement to form a new independent legal entity, whether a corporation or just a partnership, and usually JVs are limited to a certain joint task or goal to be achieved, and at some other times it is even limited to certain short or long periods. ${ }^{447}$ Moreover, the new independent legal entity resulting from the JV might be directly managed or at least controlled by all the parties to the JV agreements, and it has been reported that the parties to the JV agreement might be competitors but they share a common goal that serves their interests. ${ }^{448}$

In a JV, parties pool their resources to reach the planned common goal or task, and in that context many successful examples of JVs could be listed, most notably in the car manufacturing industry in the US and Japan. A prime example in that regard is the JV between two giant car corporations, Chrysler Motors and Mitsubishi Motors, to manufacture cars in a new manufacturing facility in Bloomington, Illinois. ${ }^{449}$ On February 20, 2001 two giant fast-moving consumer goods industry corporations, namely Coca-Cola and P\&G, entered into a JV agreement to develop a new 4.2 billion US dollars corporation for juices and snacks, which is undoubtedly considered as another successful JV example. ${ }^{450}$

It should be mentioned here that in addition to the usual benefits of reaching common goals, corporations might enter into a JV agreement for many other purposes. For instance, some corporations enter into a $\mathrm{JV}$ in order to circumvent the barriers that might be facing some of the

445 DePamphilis, Mergers and Acquisitions Basics: All You Need to Know, supra note 238 , at 19.

446 See generally Dinesh Nair, Qatar Builds up Xstrata Stake Ahead of Glencore Deal (Thomson Reuters 2012); Jesse Riseborough, et al., Qatar Holds Out on Glencore as Davis Heads for Exit (Bloomberg News 2012).

447 DePamphilis, Mergers and Acquisitions Basics: All You Need to Know, supra note 238, at 18-19; SHERMAN, Mergers \& Acquisitions from A to Z, supra note 384 , at 256 .

448 Shenefield \& STElzer, The Antitrust Laws: A Primer, supra note 178, at 54.

449 Gaughan, Mergers, Acquisitions, and Corporate Restructurings, supra note 237 , at $19-20$.

450 Weston \& Weaver, Mergers and Acquisitions, supra note 239, at 124. 
parties as a foreign investment; ${ }^{451}$ or foreign corporations enter into a JV with local corporations to circumvent the laws that control the foreign investments or activities in certain industries within the US, ${ }^{452}$ and more significantly in China. Despite the fact that it has been reported that the JV as an option for growth started to lose favor as a merger alternative due to its problems, which are in fact similar to those facing merger transactions, ${ }^{453}$ it might be beneficial to discuss the Chinese experience in some detail.

China is in fact the most important example here because, first, it is the leading receiver of FDIs among all the developing countries, i.e. inbound FDIs; secondly, China is the leading user of FDIs as an acquirer of foreign corporations i.e. outbound FDIs; 454 and thirdly, the Chinese SWF is ranked as fifth among all other SWFs, with concern as to the volume of its outbound FDI activities. ${ }^{455}$ In that context, and as an explanation for the high number of inbound FDIs in general, there is empirical evidence that reveals that corporations generally preferred the $\mathrm{JV}$ as a mode of FDI or entry to the restrictive closed markets, such as China. ${ }^{456}$

On the other hand, that explanation should not be generalized because that is not always the case, whereas the corporation in most cases is obligated to use the JV option as a mode of entry, in order to circumvent the restrictive practices of banning the acquisition of a national corporation in certain industries or the requirement of the presence of a national partner with a specified share percentage to enter into certain industries. That concept will be considered in more detail in the discussion of the impediments that cross-border mergers face. ${ }^{457}$

451 Weston \& Weaver, Mergers and Acquisitions, supra note 239, at 124.

452 For more details about laws limiting foreign investments and activities in certain industries in the US, see REED, et al., The Art of M\&A, supra note 359, at 907-911.

453 Ian Coleman, Emerging Markets and M\&A Activity, in 2008 INTERNATIONAL Mergers \& Acquisitions: Creating Value in an Increasingly Complex Corporate Environment at 51 (Financier Worldwide Booz \& Company ed. 2008).

454 Mattia Colonnelli de Gasperis, et al., International M\& $A$ and Joint Ventures, 43 INTERNATIONAL LAWYER 367, at 389, 403 (2009).

455 For the full profile of the Chinese SWF see http://www.swfinstitute.org/ swfs/china-investment-corporation (last visited December 1, 2017).

456 Yung-Heng Lee, et al., An Empirical Study of Wholly-Owned Subsidiaries and Joint Ventures for Entry into China Markets, 3 Global Journal of Business RESEARCH 9, at 16 (2009).

457 See infra p.176. 
Further, concerning the explanation of the booming outbound FDIs from China, it has been claimed that they are significantly increasing due to the fact that Chinese corporations are acquiring experience and transfer technology by entering into cross-border JVs with foreign corporations. ${ }^{458}$ Accordingly, it could be argued that facilitating the path for FDI to use JV as a mode of entry will not only benefit the domestic economy in the hosting country, but it will also benefit the foreign corporations and their national economies in other countries.

It should be noted that China, in order to fully utilize and reap the benefits of the JV option, adopted a JV law on July 1, 1979, which was amended on April 4, 1990, and was then amended for the second time on March 15, 2001. It was also reported that since the adoption of that JV law inbound FDI proliferated exponentially by means of JVs. ${ }^{459}$ Meanwhile, it has been reported that the actual number of operating JVs in China is almost a third of the registered JVs, ${ }^{460}$ and just taking the registered JVs' number into consideration to evaluate the Chinese JV experience might lead to a false indication in that regard.

At the same time, it could be claimed that the proliferation in JV transactions in China seems not only limited to the proliferation of JVs as an idea, but is also due to the fact that China is generally witnessing a booming economy, even during periods of global financial crises. For instance, it has been reported that while the US and many other Western economies in the world witnessed almost a 30 percent decrease in merger activities during the financial crisis of 2008, China witnessed an increase of at least 1 percent in merger activities. ${ }^{461}$

In addition to the efforts to attract the FDI generally, and the use of JV especially as a mode of market entry, China issued a specialized catalogue to guide investors planning to use FDI in China in 1995, and that catalogue is updated periodically, with the most recent being the 2017 version. ${ }^{462}$ It has been claimed that the catalogue categorizes the industries into three main categories: The first is the category of encour-

458 Karl P. Sauvant, et al., Foreign Direct Investment by Emerging Market Multinational Enterprises, the Impact of the Financial Crisis and Recession and Challenges Ahead (OECD Investment Divison 2009).

459 Paul W. Beamish \& Hui Y. Wang, Investing in China via Joint Ventures, 29 Management International Review 57, at 57 (1989).

$460 \quad I d$. at 62.

461 Gasperis, et al., INTERNATIONAL LAWYER, supra note 454, at 388-389.

462 The English version of the catalogue is available on the official website of the Chinese government at http://www.fdi.gov.cn/1800000121_39_4851_0_7.html (last visited December 1, 2017). 
aged industries, the second is the category of restricted industries, and the third is other industries not included in either of the first two categories, and that is a permitted industries category. ${ }^{463}$

That claim is not completely accurate because the general rule in China is that if something is not restricted it does not mean that it is permitted, ${ }^{464}$ and that is generally the trend in most developing countries, not just China. In addition to that the authorities in China do not apply only the law but also apply the directives as spelled out by the government authorities as compulsory rules for implementing the general rules that are stipulated by law; those directives are known as the "Red-Title Documents." 465

The most important remark on that investment catalogue is that many of the FDI opportunities that are spelled out in it are reserved just for the JV route, such as the business of cultivating traditional Chinese medicines; exploitation and utilization of coal-bed gas, petroleum, and natural gas; and most notably the manufacturing of material for high-technology semiconductors. The Chinese efforts are also extended to encourage JVs and FDI in general through other actions taken by government officials, such as developing a policy to attract professional human resources to be an added value to the economy, and that will undoubtedly be considered an added value to the FDI environment in China. ${ }^{466}$

Meanwhile, there were also empirical findings that indicate that some corporations did not prefer the cross-border JV as a growth alternative in China for many reasons: (1) the fear that the JV will not sufficiently protect intellectual property rights (hereinafter IPR) owned by them; ${ }^{467}$ (2) discrimination against JVs that are owned by foreign corporations, especially as concerns government procurements; ${ }^{468}$ (3) lack of coordination

463 Stephen Chan, Rules and Issues Surrounding M\&A with Chinese Companies, in 2008 International Mergers \& AcQuisitions: Creating Value IN aN InCREASINGLy COMPLEX CoRporate ENVIRONMENT at 341 (Financier Worldwide Booz \& Company ed. 2008).

464 Fei Guoping, How to Speed Up M\& A Deals in China, in 2008 InTERnATIONAL Mergers \& Acquisitions: Creating Value in an Increasingly Complex Corporate Environment at 333 (Financier Worldwide Booz \& Company ed. 2008).

$465 I d$.

466 International Economic Research Division, Global Investment and Trade Report, Japanese External Trade Organization 1, at 10 (2014).

467 Lee, et al., Global Journal of Business Research, supra note 456, at 19.

468 Ken Davies, China Investment Policy: An Update, 2013 OECD WorkIng Papers on Internatioinal InVestment 1, at 3 (2013); Guoping, How to Speed up M\&A Deals in China, supra note 464, at 333. 
between the different regulators in China; ${ }^{469}$ (4) the JV option will not provide the full sole control that might be offered by other growth alternatives, and accordingly the JV will not fully serve the interests of the shareholders of the investing corporation; (5) lack of harmonized standards with the global economy and that includes not only production standards, but also management schemes etc.; (6) short-term orientation or mindset of the Chinese partner in the JV; (7) foreign partners in a $\mathrm{JV}$ in China always expect to suffer foreign exchange difficulties ${ }^{470}$ and profit remittance problems; and (8) the JV option might lead to taxation complexities similar to those caused by mergers. ${ }^{471}$

Likewise, it was also claimed that the JV as a growth option has anticompetitive effects on the markets, as well as mergers, and in that context it should be noted that the empirical findings of the research done in that regard revealed that pure domestic JVs have more positive effects on the economy than cross-border JVs, and even that pure domestic horizontal JVs have fewer negative effects on the economy than cross-border JVs, and that the strong belief that JVs are pro-competitive is not an accurate hypothesis. ${ }^{472}$

Accordingly, it could be declared that the Chinese experience in using the JV as a mode of entry for FDI is the closet growth option to mergers, and while it could be used to overcome some of the impediments that crossborder mergers face, which will be discussed later in detail, the JV is not a cost-free transaction as might be imagined, because planning for a successful JV will consume nearly all the same resources as a merger. ${ }^{473}$ However, as was mentioned, it is a preferred option in many closed developing economies, used for the purposes of circumventing the FDI limitations that are imposed in those jurisdictions, ${ }^{474}$ and in return the investing corporation will reap most of the benefits of the growth opportunity but with some limitations, especially with regard to the full control over the JV.

469 Davies, OECD Working Papers on Internatioinal Investment, supra note 468 , at 31 .

470 Beamish \& Wang, Management International Review, supra note 459, at 62 .

471 Sherman, Mergers \& Acquisitions from A to Z, supra note 384, at 259.

472 Tony W. Tong \& Jeffrey J. Reuer, Competitive Consequences of Interfirm Collaboration: How Joint Ventures Shape Industry Profitability, 41 Journal of INTERNATIONAL BUSINESS STUDIES 1056, at 1069 (2010).

473 Christoph Reimnitz, Exploring the Potential of Joint Ventures to Create Value as Opposed to Outright $M \& A$, in 2008 InTERnATIONAL Mergers \& ACQUisitions: Creating Value in an Increasingly Complex Corporate Environment at 115 (Financier Worldwide Booz \& Company ed. 2008).

474 Weston \& WeAver, Mergers and Acquisitions, supra note 239, at 124. 
By the same token, the JV as a mode of entry is also regulated under the same rules that control mergers in almost all the jurisdictions in the world ${ }^{475}$ In the same context, it was suggested that the foreign corporation will always show a tendency to fully acquire the JV, i.e. buyout the local corporation shares, if the JV appeared to be successful. ${ }^{476}$ That means that the corporation, if not obligated under a restricting closed market regime and in order to fully utilize the growth possibility, should turn the JV into an actual merger, wholly owned and fully controlled by the corporation.

An example of a giant corporation that refused to enter into a JV with a local partner in China is the American insurance corporation AIG, where it was even reported that that corporation lobbied the US government to oppose China's accession to the World Trade Organization (hereinafter WTO) until it waived the requirement of entering into a JV with a local partner in order to enter into the insurance industry in China. In the end, AIG was granted the right to continue its operations in China without entering into a JV with a local partner. ${ }^{477}$

Corporations might enter into JV agreements for the purpose of reducing the risks, or even eliminating the unplanned risk that might appear when entering into a new business alone, and that could be simply by dividing risk among all the parties of the JV. ${ }^{478}$ It should also be noted here that the horizontal JV transactions are used heavily as a merger alternative, ${ }^{479}$ and that is obviously to circumvent impediments that the typical horizontal merger transaction might face.

On the other hand, franchising is a totally different growth alternative, where the concerned parties enter into a franchising agreement under which a party, "the franchisor," grants another party, "the franchisee," the right to manufacture or sell the products or services or even just use the name and the business model of the franchisor, and under that agreement

475 For more practical details about the transactions that should be notified or controlled under the merger control system in 60 different jurisdictions see JAMES Musgrove \& Eva Bonacker, 2017 Pre-Merger Notification Manual: A PraCtical Guide to Understanding Merger Regimes in Multiple Jurisdictions (Terralex. 2017).

476 Coleman, Emerging Markets and M\&A Activity, supra note 453, at 51.

477 David L. Levy \& Aseem Prakash, Bargains Old and New: Multinational Corporations in Global Governance, 5 Business AND Politics 131, at 135 (2003).

478 Sherman, Mergers \& Acquisitions from A to Z, supra note 384, at 256; WeSTON \& WeAVER, Mergers and Acquisitions, supra note 239, at 123.

479 Sherman, Mergers \& Acquisitions from A to Z, supra note 384, at 259. 
they also share some of their resources in return for sharing profits. ${ }^{480}$ That form of a growth alternative, i.e. franchising, is widespread in the fast food industry, ${ }^{481}$ and also the hotel industry. Franchising is almost at no cost to the franchisor but will designate some of its resources to the success of the franchise. ${ }^{482}$

Licensing is also another and almost free growth alternative. ${ }^{483}$ Here the concerned parties enter into licensing agreement under which the owner of an IPR, i.e. "the licensor," grants another party, "the licensee," the right to use or exploit the IPR, without transfer of ownership, in exchange for some royalties, which are almost always less than the profits expected. ${ }^{484}$ In that context, it should be noted that licensing is a widespread growth alternative in the pharmaceutical and technological industries. ${ }^{485}$ Licensing is also of a great advantage to the licensee because the licensee will be granted access to the developed IPR without investing or using resources in its development. ${ }^{486}$

Likewise, distributorships and dealerships, which are mainly classified as exclusive agreement growth alternatives, are to a great extent an option that is parallel to franchising and licensing, whereas the owner of the rights to sell certain products or services enters into an agreement to grant an independent party, "the dealer" or "the distributor," the right to exclusively sell that product or service. ${ }^{487}$ These exclusive agreements usually grant owners access to new markets beyond their reach. ${ }^{488}$

Furthermore, these exclusive agreements almost always give selling rights that are limited to certain markets or certain geographic areas, or even limited to a certain category of consumers, and they might also be

480 Weston \& WeAver, Mergers and Acquisitions, supra note 239, at 129; DePamphilis, Mergers and Acquisitions Basics: All You Need to Know, supra note 238, at 19; SHERman, Mergers \& Acquisitions from A to Z, supra note 384, at 261.

481 DePamphilis, Mergers and Acquisitions Basics: All You Need to Know, supra note 238, at 19.

482 Sherman, Mergers \& Acquisitions from A to Z, supra note 384, at 262; DePamphiLis, Mergers and Acquisitions Basics: All You Need to Know, supra note 238 , at 19 .

483 DePamphiLIs, Mergers and Acquisitions Basics: All You Need to Know, supra note 238 , at 19.

484 Sherman, Mergers \& Acquisitions from A to Z, supra note 384, at 256, 272.

485 For more details about examples from the pharmaceutical industry see

Weston \& Weaver, Mergers and Acquisitions, supra note 239, at 128-129.

486 DePamphiLis, Mergers and Acquisitions Basics: All You Need to Know, supra note 238 , at 19 .

487 Sherman, Mergers \& Acquisitions from A to Z, supra note 384, at 279.

488 WeSTON \& WEAVER, Mergers and Acquisitions, supra note 239, at 128. 
limited for a certain time or period. ${ }^{489}$ It is noteworthy that under the exclusive agreements model the owner will exercise less power over the dealer or the distributor than in the franchising or licensing models, but those exclusive agreements are classified as franchising agreements in some legal systems, and that might lead to very complicated problems unless otherwise clearly mentioned that there are minimal control powers granted to the owner. ${ }^{490}$

Lastly, the strategic alliance alternative is to a great extent a flexible form of JV ${ }^{491}$ whereas in a strategic alliance there are some significant differences: first, ranging from minimal to no formal or written agreement is required, which mainly saves financial resources and increases flexibility; ${ }^{492}$ second, the parties will use their own legal entities and no new independent legal entity will be developed ${ }^{493}$ third, it is characterized by uncertainty and ambiguity of the terms, and the relation between the parties depends mainly on the trust between them; ${ }^{494}$ fourth, parties to the strategic alliance coordinate but each takes decisions more independently; ${ }^{495}$ fifth, no capital contributions are required; ${ }^{496}$ and sixth, strategic alliances are always temporary or even limited by time. ${ }^{497}$

Finally, it is significant that some corporations use mergers and all those growth alternatives at different stages during their history, and even may use some or all of them combined together at the same time. Scrutinizing the history of a corporation like Mail Boxes ETC will reveal that it used franchising as a growth option in the early 1980s and then in 1990 the United Parcel Corporation acquired a minority but significant percentage of its shares (15 percent). Next, Mail Boxes ETC entered into a JV with USA Technologies to jointly market one of its products (MBE Express),

489 Sherman, Mergers \& Acquisitions from A to Z, supra note 384, at 279-280.

490 For more details about these problems under the US legal system see REED, et al., The Art of M\&A, supra note 359, at 563.

491 Gaughan, Mergers, Acquisitions, and Corporate Restructurings, supra note 237 , at 21 .

492 Weston \& WeAVER, Mergers and Acquisitions, supra note 239, at 125; DePamphiLis, Mergers and Acquisitions Basics: All You Need to Know, supra note 238 , at 19 .

493 Gaughan, Mergers, Acquisitions, and Corporate Restructurings, supra note 237 , at 21 .

494 James Sawler, Horizontal Alliances and the Merger Paradox, 26 MANAGERIAL and Decision Economics 243, at 247 (2005); Weston \& Weaver, Mergers and Acquisitions, supra note 239, at 126.

495 Sawler, Managerial AND Decision Economics, supra note 494, at 243-244.

496 Sherman, Mergers \& Acquisitions from A to Z, supra note 384, at 258.

497 Sawler, Managerial AND DeCision Economics, supra note 494, at 247. 
then U.S. Office Products acquired Mail Boxes ETC through a 267 million US dollars transaction, and then it entered into strategic alliance with iShip.com. ${ }^{498}$

\section{Merger Dynamics}

As was previously mentioned, this book is limited to friendly mergers and it will not address the hostile takeover because the hostile takeover is governed by a different set of rules. That is mainly because in hostile takeover transactions the acquirer is an opportunity taker, which obviously means that the transaction is most probably unplanned and therefore it will be difficult, if not impossible, to predict its procedures, structure, and dynamics.

Scrutinizing the merger dynamics is crucial because a solid understanding of these is a prerequisite to delving into the impediments to the merger process. In that regard, it has been claimed that scrutinizing every single step in the merger dynamics is essential to understanding the remaining steps, and that both the acquirer and the target should "drink at the ever-renewing spring of M\&A knowledge [and to] drink deep, they must recognize first that there is something called an acquisition process, with many crucial stages. .. ."499 In addition to that, scrutinizing the merger dynamics is undoubtedly a very helpful tool toward understanding how impediments could be removed or at least managed.

This discussion will be devoted to the dynamics of mergers, and it will address first how the target may prepare itself for a future merger and screen for a prospective acquirer. Next it will examine the preliminary agreement that might be entered into by parties as a second step. The third step will also address the comprehensive appraisal of the target, i.e. due diligence ${ }^{500}$ and valuation. This will be followed by the fourth step, which will review how the transaction could be structured and financed. Finally, the discussion will address the closing of the transaction as the fifth step.

\section{(a) Preparation and screening}

Whatever the incentives are for entering into a merger, whenever a target decides to go into a merger, or even a prospective acquirer approaches it, it

498 Weston \& WeAver, Mergers and Acquisitions, supra note 239, at 130.

499 REED, et al., The Art of M\&A, supra note 359, at 2.

500 The term "due diligence" was originally used by Section 11 of the Securities Act of 1933 (codified at 48 Stat. 74, 15 U.S.C. $\$ \$ 77$ a et seq.) as a defense against liabilities on account of a false registration statement, with regard to the publicly traded corporations on the stock exchange. 
will be of a great benefit to first go through preparations. ${ }^{501}$ Preparing the target for a merger could easily be shortened in what is known as "getting the house in order." ${ }^{202}$ In order to successfully accomplish that step the target should first start by assembling its preparation team, and typically that team will include its own in-house accounting, financial, legal, and corporate affairs team, if any, and, in addition to that, it may also seek other external professionals' services like investment bankers, tax advisors, estate planners, etc. ${ }^{503}$

The main task for the preparation team will be simply to get the house in order, and that might include finalizing all pending financial, accounting, legal, tax, and estate issues, making all documents and records clear and available, and also making a preliminary valuation of the target among a long list of preparation tasks. ${ }^{504}$ That team should mainly perform its mission with a single goal in mind, which is to maximize the value of the target and to make it more appealing to potential acquirers, and in that regard it has been claimed that an unprepared or even "poorly" prepared target will be less appealing to prospective acquirers or at least will delay closing the transaction in the proper time. ${ }^{505}$

Searching for a prospective "dancing partner" in the merger transaction, whether it is an acquirer or a target, which is known as the screening process, is an important part of the preparation step or at least directly related to it. ${ }^{506}$ In the screening process the corporation by itself or with the help of an intermediary, which is typically an investment banker or just a broker, ${ }^{507}$ will draw an exhaustive list of the most qualified acquirers or targets. ${ }^{508}$ Almost all of those corporations that are included in the list should fit into the merger planning or strategy, ${ }^{509}$ but obviously not all

501 MiLler, Mergers and Acquisitions: A Step-by-Step Legal and Practical Guide, supra note 407, at 23.

502 Sherman, Mergers and Acquisitions from A to Z, supra note 384, at 21.

503 Richard Lieberman, Preparing a Company for Sale to Maximise Value, in 2008 International Mergers \& ACQuisitions: Creating Value IN AN InCREASINGly COMPlex Corporate Environment at 69 (Financier Worldwide Booz \& Company ed. 2008).

504 Sherman, Mergers \& Acquisitions from A to Z, supra note 384, at 21.

505 Lieberman, Preparing a Company for Sale to Maximise Value, supra note 503 , at 68 .

506 Sherman, Mergers \& Acquisitions from A to Z, supra note 384, at 22.

507 It has been reported that the fees of investment bankers are lower than those of brokers, see MiLLER, Mergers and Acquisitions: A Step-by-Step Legal and Practical Guide, supra note 407, at 26.

508 Sherman, Mergers \& Acquisitions from A to Z, supra note 384, at 29.

509 REED, et al., The Art of M\&A, supra note 359, at 31. 
of them will have the same willingness to enter into the proposed merger; therefore the list should be narrowed after approaching them, in order to identify the prospective acquirer or target.

After the parties to the proposed merger transaction have found common ground and demonstrated their interest in the transaction, they will usually develop a plan with a timetable in order to proceed to the next step of the merger process. Toward the closing of the transaction, they may well enter into a preliminary agreement or something similar to that effect, which will govern all the subsequent steps, ${ }^{510}$ as will be discussed in the following section.

\section{(b) Preliminary agreement}

By reaching this step the parties are more serious about entering into the proposed merger, and that accordingly requires developing an action plan and putting it into effect, and entering into a preliminary agreement that includes the terms and conditions that would govern all the remaining planned steps until closing the transaction, or even some postclosing issues, and also how the process might be terminated. That kind of preliminary agreement is recognized under various legal systems and is usually called a "Letter of Intent," "Term Sheet," "Heads of Agreements," or simply "Preliminary Agreement." 511

Meanwhile, entering into that kind of agreement is not a worldwide practice, and it has been argued that it is impractical in some cases and even problematic in other cases, especially if one of the parties of the proposed merger is a publicly traded corporation. For instance, under securities regulations in the US, entering into such agreement might be considered a premature merger announcement for the purpose of influencing the prices of the shares on the stock exchange. ${ }^{512}$ Accordingly, these agreements should be carefully drafted, and the parties sometimes draft them and agree to their terms but do not sign them, and they even adopt a "no comment" policy as a response to any inquiries concerning the proposed merger transaction. ${ }^{513}$

\footnotetext{
510 Sherman, Mergers \& Acquisitions from A to Z, supra note 384, at 49.

511 Robert Coyne \& Kevin Evans, Non-binding Preliminary Agreements: Use 'Good Faith' With Caution, in 2008 InTERnATIONAL Mergers \& ACQUisitions: Creating Value in an Increasingly Complex Corporate Environment at 74 (Financier Worldwide Booz \& Company ed. 2008).

512 Miller, Mergers and Acquisitions: A Step-by-Step Legal and Practical Guide, supra note 407, at 43.

513 Thomas Lee Hazen, Rumor Control and Disclosure of Merger Negotiations: Full Disclosure or "No Comment"-The Only Safe Harbors, 46 Maryland Law REVIEW 954, at 961 (1987).
} 
However, it should be noted that the preliminary agreement usually governs all the issues concerning the remaining steps of the merger process, and that might be different from case to case. Meanwhile, in most of the cases it will address the main general terms and conditions, among which are the following issues: (1) granting access to books and records, (2) protecting confidential information, (3) publicity and announcements concerning the transaction, (4) merger process expenses, (5) fees of the brokers, (6) the expected effect of the transaction on employees, (7) conditions for closing the transaction, (8) operations during the merger process, (9) key terms to be incorporated in the closing agreement, and (10) timetable with deadlines. ${ }^{514}$

Generally speaking, the parties are always concerned with allocating the risk of the transaction between them, which could be accomplished through the terms incorporated in the preliminary agreement, and it has even been reported that for such purpose the parties might enter into an insurance agreement specially designed for merger transactions. ${ }^{515}$ In addition to those general terms, the preliminary agreement may contain some other crucial provisions concerning the following issues: (1) conducting negotiations in good faith, (2) locking up the transaction, and (3) termination and break-up of the process. Each of these additional provisions will be discussed in turn.

Concerning the "good faith" provision, some preliminary agreements include such a provision, which generally requires the parties to negotiate in good faith, but that kind of provision is not similarly recognized in all the countries around the world; at one end of the spectrum that provision has no legal impact in the UK, while in Australia it has some impact if it is clearly mentioned that the agreement itself is binding; at the other end of the spectrum the provision is binding even if it was expressly mentioned in the preliminary agreement that it is not a binding agreement in most of the US jurisdictions. ${ }^{516}$ Accordingly, in a cross-border merger transaction, using that provision might have different interpretations and that might end with a dispute before the courts.

514 Sherman, Mergers \& Acquisitions from A to Z, supra note 384, at 52, $56-58$.

515 Walt Lemanski, Risk Allocation-Driving Force Behind the M\&A Process, in 2008 International Mergers \& Acquisitions: Creating Value in aN InCREASINGLY COMPLEX CORPORATE ENVIRONMENT at 106 (Financier Worldwide Booz \& Company ed. 2008).

516 For more details about the impact of the "good faith" provision in the UK, Australia, and the US, see generally Coyne \& Evans, Non-binding Preliminary Agreements: Use 'Good Faith' with Caution, supra note 511, at 74-76. 
In the same context, it has been claimed that the "good faith" provision in the preliminary agreement might conflict with the directors' obligations (good faith, fiduciary duty of care, and loyalty) in the US legal system. ${ }^{517}$ To elaborate further, the obligation to negotiate the merger transaction in "good faith" might lead to missing some other opportunities with a third party. Those opportunities might better serve the shareholders' interests, and this is highly problematic because there is no clear standard that defines the directors' obligations in that regard. ${ }^{518}$ As a clearer, precise, and more effective alternative to the "good faith" provision, the parties may clearly state and define their obligations with regard to the negotiation process and the consequences in the event of breach instead of these generalized vague obligations. ${ }^{519}$

The parties, mainly the acquirer, may wish to save their interest in the transaction and not to waste their resources by finding that the transaction ends up intended for a third party. Accordingly they might incorporate a lock-up provision in the preliminary agreement, or what are known as "non-solicitation" or "no-shop/no talk" provisions, and under those lock-up provisions the target is banned from entering into negotiations or even talks concerning other proposals with third parties, at least for a certain period. 520

One more time, that kind of provision is also highly problematic in some jurisdictions, especially in the US, because it might also conflict with the directors' obligations (good faith, fiduciary duty of care, and loyalty) ${ }^{521}$ As a clearer alternative, it could be argued that that kind of lock-up provision would be better replaced by a termination provision, i.e. setting out all the consequences in the event the target terminated the process for any reason.

On the other hand, as an example of the termination provision, the parties may agree to set certain fees to be paid in the event the acquirer did not close the transaction, or the target terminates the process as a result

\footnotetext{
517 ReED, et al., The Art of M\&A, supra note 359, at 790.

518 Jessica Toonkel, Skepticism Rises Around SEC Fiduciary Rule (Thomson Reuters 2012).

519 Coyne \& Evans, Non-binding Preliminary Agreements: Use 'Good Faith' with Caution, supra note 511, at 77.

520 John Mackie, Deal Protection in a Tough Market No Talks and Go Shops (Thomson Reuters 2011).

521 Miller, Mergers and Acquisitions: A Step-by-Step Legal and Practical Guide, supra note 407, at 28; for more details about one of the most famous cases that increased uncertainty in lock-up provision practice, especially in publicly traded corporations, see the Delaware Chancery Court decision in Omnicare, Inc. v. NCS Healthcare, Inc., 818 A. 2d 914 - Del: Supreme Court 2003.
} 
of a third-party offer. Those kinds of provisions are known as "reverse termination fees," "break-up fees," or simply as "termination fees", ${ }^{522}$ and those provisions are of a great importance and have great implications in almost all the cases in several jurisdictions.

To better understand the importance and the implications of such termination provisions, consider the fact that the percentages of termination fees reached up to 19.4 percent of the estimated purchase price of the target in some transactions during 2011. ${ }^{523}$ Furthermore, it was also reported that in 2011 AT\&T paid 3 billion US dollars as reverse break fees to Deutsche Telekom AG because it did not close the transaction, regardless of the fact that the transaction was blocked by the authorities in the US, i.e. the US Department of Justice (hereinafter DOJ), despite the fact AT\&T was not responsible for its failure. ${ }^{524}$

Meanwhile, it has been reported that the termination provisions are not recognized in all jurisdictions in the same manner. High fee percentages are not acceptable in some jurisdictions, for example in some jurisdictions of the US it is only acceptable to the courts for termination fees to be set within the maximum range of 2-3 percent of the estimated purchase price of the transaction..$^{525}$

In the same context, it should be noted that some of the termination provisions in the preliminary agreements are not just straightforward provisions, i.e. not just setting a certain percentage of the estimated purchase price, as a break-up fee. Termination provisions could be designed and drafted in a tiered structure, which means that the percentage is not fixed but fluctuates according to certain scenarios. For example, in the transaction between Medco Health Solutions and Express Scripts the termination fees ranged from 650 million US dollars to 950 million US dollars. ${ }^{526}$ Meanwhile, the tiered structure of the termination provision will inevitably increase the risks and uncertainties during the merger process.

Finally, it has also been reported that such termination provisions are

522 Marc C. D’Annunzio \& Wayne N. Bradley, Drafting and Negotiating Purchase Agreements to Anticipate Challenges, in 2008 InTERnational Mergers \& Acquisitions: Creating Value in an Increasingly Complex Corporate ENVIRONMENT at 102 (Financier Worldwide Booz \& Company ed. 2008).

523 Alex Lee, Reverse Termination Fees Escalation in an Uncertain Environment (Thomson Reuters 2011).

524 Alex Lee, A Global Review of Merger and Acquisition Activity (Thomson Reuters 2011).

525 D'Annunzio \& Bradley, Drafting and Negotiating Purchase Agreements to Anticipate Challenges, supra note 522, at 102.

526 Lee, Reverse Termination Fees Escalation in an Uncertain Environment, supra note 523, 2011. 
not only widely accepted between parties, but also some acquirers might prefer to pay high termination or break-up fees instead of entering into an overvalued transaction, ${ }^{527}$ and it is noteworthy here that the target valuation and determining whether it is overvalued or not will be identified in the next step in the merger process, i.e. the step of due diligence and valuation, as will be addressed in the following discussion.

\section{(c) Due diligence and valuation}

In the due diligence and valuation step the parties will put the transaction into a "reality test" to deeply examine the records and documents, in order to decide whether the transaction is of a real value as it looks or not. ${ }^{528}$ In other words, the parties will examine the results accomplished by the preparation team, during the preparation and screening step, in order to make sure that the proposed or expected value is realistic and is not just a synthesized value by a professional team, and it is undoubtedly true that the results of that examination, i.e. the due diligence, will inevitably affect the final decision as to whether to enter into the transaction or not. ${ }^{529}$

The due diligence mainly involves the examination and the analysis of all the records and documents of the target from legal, financial, and accounting perspectives. Moreover, from all those perspectives, the main tasks of due diligence include the assessment of the current situation of the target, valuating the expected benefits from the transaction, identifying potential risks and any impediments to closing the transaction, and gathering all the information that will be used in the next steps, for example information that will possibly be used to structure and finance the transaction..$^{530}$

The documents to be checked by the acquirer's representing team during the due diligence might be classified into hundreds of categories, ${ }^{531}$ and it is not easy, if not impossible, to draw up an exhaustive list of the documents, but as guidance, some authors have tried to classify those

527 Derek Stoldt, Deal Certainty and Recent Dislocations in the Credit and M\&A Markets, in 2008 International Mergers \& Acquisitions: Creating VALUE IN AN INCREASINGLY COMPLEX CORPORATE ENVIRONMENT at 99 (Financier Worldwide Booz \& Company ed. 2008).

528 Sherman, Mergers \& Acquisitions from A to Z, supra note 384, at 63.

529 REED, et al., The Art of M\&A, supra note 359, at 381-382.

530 Sherman, Mergers \& Acquisitions from A to Z, supra note 384, at 64.

531 For more details about the general list of documents to be examined during due diligence, see generally MiLLER, Mergers and Acquisitions: A Step-by-Step Legal and Practical Guide, supra note 407, at 51-56, 60-63. 
documents under key categories. Under the corporate affairs category there is a huge list that starts with all documents related to corporate registrations, by-laws, and any amendments thereof, board and shareholder meetings' minutes, and all corporate affairs-related management reports. Under the financial issues category, there is also an enormous list that exceeds the corporate affairs category as it includes, but is not limited to, all the financial information, starting from taxation documents, auditing reports, books, all documents related to debt and financing issues, financial statements, balance sheets, and all the management reports related to finance. ${ }^{532}$

Moreover, under the employment category there is also a massive list that might include, for example, all employment agreements; consulting and management agreements; all benefits plans, especially those for the top-tier management team, unions, or collective agreements; all documents proving compliance with regulatory issues such as those rules issued by the US Equal Employment Opportunity Commission, those required under the Occupational Safety and Health Act, ${ }^{533}$ and those adopted by the administration at the United States Department of Labor; and all the employment policies that are adopted internally. ${ }^{534}$

Furthermore, under the assets category there is another gigantic list, no less than the list under the previous categories, and that might include, for example, documents related to real estate registrations and taxes; insurance plans; all agreements related to real estate transactions such as rent, purchase, and mortgages; and all documents related to IPR. ${ }^{535}$ In that regard, it should be noted that assets registration, especially of land, is highly problematic under most legal systems, and that real estate registration issues represent a high percentage of the legal issues that might be discovered during due diligence; it has even been reported that targets operating in the agriculture industry have always been acquired at an underestimated value for that very reason. ${ }^{536}$

Ironically, it is not even easy to draw up the list of categories of the lists themselves. For instance many other categories could be listed, such as all documents related to domestic and overseas operations; documents related

\footnotetext{
532 Sherman, Mergers \& Acquisitions from A to Z, supra note 384, at 69-71.

533 Occupational Safety and Health Act of 1970, U.S.C. $\S 651$ et seq.

534 Sherman, Mergers \& Acquisitions from A to Z, supra note 384, at 71-72.

535 Id. at $72-73$.

536 Bogdan Borovyk \& Ekaterina Katerinchuk, Sector-Specific M\&A in Ukraine, in 2008 InTERnATIONAL MERgers \& ACQUisitions: Creating Value In AN InCREASINGLy COMPleX Corporate Environment at 291 (Financier Worldwide Booz \& Company ed. 2008).
} 
to filing and licensing issued by industry-specific regulatory authorities and all compliance reports thereof; documents related to all the business agreements whether already performed or still pending; and documents related to any pending or anticipated disputes that are discovered during what is known as the "litigation analysis." 537

It could easily be claimed that those huge lists of documents are not only highly problematic because it is not easy to accurately draw up an exhaustive list for them, but also because the examination of such documents might lead to disclosing confidential information to the acquirer, disturbance of daily operations by conducting on-site visits, and finally consuming the parties' resources. However, regarding the confidentiality of the information that might be disclosed during the due diligence step, it was previously noted in the discussions of the preliminary agreement step, that in most cases the parties may prefer to enter into a special confidentiality agreement or incorporate a confidentiality clause in the preliminary agreement in order to properly protect their interests at that stage and during the whole process. ${ }^{538}$

In the same context, and as a solution to some of the mentioned problems, the idea of Virtual Data Room (hereinafter VDR) emerged, by which a VDR service provider will manage to upload soft copies of all the documents to an online server, and the target can easily grant the potential acquirer access to the online server. ${ }^{539}$ To demonstrate how these VDRs are useful, it should be noted that: the parties would incur no traveling or lodging expenses; $; 40$ access to certain highly confidential information might be restricted or limited to top-tier management team; documents will be available at any time regardless of different working hours or conflicting time zones, avoiding the affect and negative impact on the target's employees of what are known as "water-cooler rumor mills," which might develop during traditional on-site visits; access can be granted to several potential acquirers at the same time; and even indexing and searching are easier than in traditional on-site visits. ${ }^{541}$

537 For more details about litigation analysis in due diligence see generally REED, et al., The Art of M\&A, supra note 359, at 397-399.

538 MiLler, Mergers and Acquisitions: A Step-by-Step Legal and Practical Guide, supra note 407, at 26; REED, et al., The Art of M\&A, supra note 359, at 383. 539 Miller, Mergers and Acquisitions: A Step-by-Step Legal and Practical Guide, supra note 407, at 27.

540 Angus Bradley, Sell-Side Online Datarooms, in 2008 InTERnATIONAL Mergers \& Acquisitions: Creating Value in an Increasingly Complex Corporate Environment at 137 (Financier Worldwide Booz \& Company ed. 2008).

541 Sherman, Mergers \& Acquisitions from A to Z, supra note 384, at 79; Darren Redmayne \& Saurin Mehta, Domestic Versus Foreign Acquirers: Managing 
In addition to the mentioned problems, it should also be noted that due diligence in cross-border mergers is highly complicated because the documents should be examined according to different jurisdictions. Each might have its own legal, regulatory, financial, or accounting rules that are not only different but sometimes contradictory, for instance there are conflicting issues between the rules for preparing financial statements in many countries as will be considered when discussing impediments to cross-border mergers in detail. It also could be claimed that due diligence is a highly complicated task that should be conducted by specialized professionals, to avoid fatal problems that could put the transaction at an end or even lead to more serious problems..$^{542}$

In the cross-border context, there are different trends in using external professionals to conduct or assist in carrying out the due diligence, for instance in some jurisdictions in the EU the target may finalize due diligence reports through an independent third party before engaging in serious steps with any potential acquirer, and it should also be noted that not only are the different trends and contradicting or conflicting rules problematic, but also every different jurisdiction has its own "hotbuttons" that specialized external professionals should take good care of, i.e. issues that represent a high priority for that jurisdiction. For instance, it has been reported that environment-related issues are "hot-buttons" in the US while employees" pension plans are "hot-buttons" in the UK. ${ }^{543}$

Based on the just-mentioned "hot-buttons" issue, it has been claimed that the domestic acquirer might be more aware of the target status than any other foreigner acquirer, and that might ease finalizing the due diligence step with more accurate results, ${ }^{544}$ and obviously that is also true for the publicly traded corporations, because it would be easier to get access to most of their records and financial statements due to the disclosure obligation imposed by the rules adopted in the stock exchanges in most of the jurisdictions, and that is even before the due diligence and without entering into a preliminary agreement.

It is noteworthy that the due diligence will not stop throughout all the other remaining steps during the merger dynamics, or even by closing the

An International Sale Process, in 2008 International Mergers \& AcQuisitions: Creating Value in an Increasingly complex Corporate Environment at 83 (Financier Worldwide Booz \& Company ed. 2008).

542 For more details about common mistakes in due diligence see generally

Sherman, Mergers \& Acquisitions from A to Z, supra note 384, at 56-58.

543 Redmayne \& Mehta, Domestic Versus Foreign Acquirers: Managing an

International Sale Process, supra note 541, at 83.

544 Id. at 81. 
transaction. It might be slowed down but it should not be stopped, for instance carrying out a due diligence after the closing is highly important to ease the management tasks and to check the validity of any representations that were made before the closing. In that context, the parties often incorporate a "bring-down" clause into the merger agreement, which imposes an obligation and warranties on the target to keep the financial and legal status unchanged until the closing of the transaction. ${ }^{545}$

As was previously mentioned, the main goal of the due diligence is to determine the realistic value of the target, therefore the valuation is very strongly related to the due diligence and both of them could be considered as the second step in the merger dynamics. However, successful due diligence is a prerequisite to starting the valuation process on solid ground and equipped with realistic information about the target, and undoubtedly that will also help in predicting its performance in the future. It should be noted that the valuation process might be conducted by using one of the following valuation methods.

The first method is the most common valuation method, which is the Discounted Cash Flow (hereinafter DCF) method. The DCF method is based mainly on the principle of time value of money, which means that the current value of a certain amount of money will not be the same in the future. According to the DCF method of valuation the target is valuated as follows: First, all the expected future cash flows are estimated, and then the estimated amount is discounted at a certain rate in order to determine the current value of these cash flows as if they were earned currently, not in the future. ${ }^{546}$

The second method of valuation is the Relative Valuation method, according to which determining the value of the target depends mainly on the market value of comparable corporations, and the term "comparable" within that method means that both corporations, i.e. the target and base corporations, are almost of the same size, operating in the same industry, and having the same financial status. ${ }^{547}$ The third method is the Replacement Value Method (hereinafter RVM). According to the RVM the target is valued by determining the cost of building it from scratch, and in that method not only the cost of the tangible assets are considered, but also all other "soft assets" such as, for instance, the cost of hiring the current employees. ${ }^{548}$

545 REED, et al., The Art of M\&A, supra note 359, at 410-411.

546 Sherman, Mergers \& Acquisitions from A to Z, supra note 384, at 137-139; REED, et al., The Art of M\&A, supra note 359, at 89, 108-109.

547 MiLler, Mergers and Acquisitions: A Step-by-Step Legal and Practical Guide, supra note 407, at 32-33.

548 REED, et al., The Art of M\&A, supra note 359, at 87, 104-105. 
The fourth method is Average Rate of Return (hereinafter ARR); within that method the target is simply valued by dividing the average of the expected accounting profits by the average expected investments. ${ }^{549}$ The fifth method is the payback method, which analyzes the decision as to whether to proceed to a merger according to a proposed value based on the payback period, and that period is the period after which the capital investments are recovered by the acquirer. It should be noted that in the payback method any returns beyond the payback period will be disregarded. ${ }^{550}$

The sixth method of valuation is the Internal Rate of Return (hereinafter IRR), which is sometimes referred to as Economic Rate of Return (ERR). This method is also based on the principle of time value of money like the DCF, however according to the IRR or ERR the target is valued by estimating the expected future returns not the cash flows, and then that estimated amount is discounted at a certain rate in order to determine the current value of these returns as if they were earned currently, not in the future. ${ }^{551}$

The seventh method of valuation is the Market Value Method (hereinafter MVM). The MVM is mainly used in acquiring publicly traded corporations. It depends mainly on the value of comparable corporations, and comparable here means that both corporations, i.e. the target and base corporations, have the same P/E. ${ }^{552}$ The eighth method of valuation is the Comparable Net Worth to MVM. As its name suggests, it is similar to MVM but actually with some accounting adjustments for the purposes of a more accurate valuation even by using less information, and it was designed mainly to protect minority shareholders in squeeze-out transactions. ${ }^{553}$

Despite the fact that the assessment of these valuation methods is beyond the scope of this book, it is undoubtedly true that a deep understanding of all these valuation methods will reveal that the valuation is "not a precise science [and] is based upon both objective facts and subjective beliefs and assumptions about the future performance of the [target]." ${ }^{554}$ It has even been claimed that all the known valuation methods are impractical and are "highly subjective," and the final valuation depends mainly on negotiations, and supply and demand forces, i.e. the acquirer is willing to

549 REED, et al., The Art of M\&A, supra note 359, at 87-88, 105.

${ }_{550} I d$. at $88,105-106$.

$551 \quad$ Id. at $88-89106$.

552 Id. at $89,106-107$.

553 Id. at $89,107-108$.

554 Sherman, Mergers \& Acquisitions from A to Z, supra note 384, at 28. 
pay a certain amount for the target and the target is willing to go through a merger in return for a certain amount, and the estimated valuations are usually a rough range that fits in between those amounts. ${ }^{555}$

Generally speaking, parties always enter into negotiations and even make adjustments to the valuation until the closing date in order to mitigate any fluctuations in market prices, foreign exchange rates, and other possible factors that might affect the initial valuation. ${ }^{556}$ In the same context, it is noteworthy that value is wrongfully used as synonym for price, while they could be easily distinguished; the "[v]alue is the intrinsic worth of an asset, while price is what a buyer has actually paid for it. Value essentially exists only in the minds of people, while price reflects real-world market behavior." 557

Moreover, in order to circumvent or at least to cut back any gaps there might be between the valuation of the target and what the acquirer is expecting about the performance of the target in the future, the parties usually use what is known as an "earn-out" provision. Under the earn-out provision the purchase price will be linked to the future performance, such as sales or total revenues, etc., and that provision is also held to be an incentive for the target to maintain or improve its performance. However, that may increase the purchase price in addition to mitigating the gap between the valuation and the acquirer's expectations. ${ }^{558}$

Finally, it should be noted that the due diligence and the valuation steps are almost continuous until the closing of the transaction, and they are also primarily governed by the terms and conditions of any preliminary agreement in relation thereto, like all the other steps throughout the merger process. However, if the parties are interested in proceeding to the next step in the merger process, they have to decide on which merger structure will best serve their interests and how the transaction will be financed, which will be addressed in the next discussion.

555 Miller, Mergers and Acquisitions: A Step-by-Step Legal and Practical Guide, supra note 407, at 35.

556 D'Annunzio \& Bradley, Drafting and Negotiating Purchase Agreements to Anticipate Challenges, supra note 522, at 103; MiLler, Mergers and Acquisitions: A Step-by-Step Legal and Practical Guide, supra note 407, at 50.

557 REED, et al., The Art of M\&A, supra note 359, at 79.

558 Murray Landis \& Gregg Mcconnell, Effective Earn-Out Provisions In Sale \& Purchase Agreements, in 2008 International Mergers \& Acquisitions: Creating Value in an Increasingly Complex Corporate Environment at 104-105 (Financier Worldwide Booz \& Company ed. 2008). 


\section{(d) Structuring and financing the transaction}

As was previously addressed during the discussion of merger types and classifications, the merger transaction could be executed or structured in enormous structures, and mergers could also be classified according to how the transaction was financed. ${ }^{559}$ Furthermore, it should be noted here that structuring and financing the transaction are directly related to each other; while the structure will be executed by means of financial tools, financing the transaction depends mainly on how it is structured.

Actually, both structuring and financing the transaction will mainly depend on the information that was gathered during the due diligence, as was also previously mentioned, and the more the due diligence was successfully accomplished the more the decisions that will be taken to choose the structure and the right financing tool will fit into the interests of all the parties. Generally speaking, the parties may decide to structure and finance the transaction to resemble one or more of the structures that were previously mentioned during the discussions of the merger types and classifications. ${ }^{560}$

For instance the parties may decide to structure their transaction as one of the following: (1) direct merger, (2) triangular merger, (3) reverse triangular merger, (4) statutory merger, and (5) subsidiary merger; or even one of the nontraditional structures like: (1) dividend access share, (2) exchangeable share, and (3) equalization structure, or any other of the previously discussed structures. Moreover, they may decide to finance the transaction either through debt or equity, and they might use any of the previously discussed financing options, for example: (1) leveraged buyouts (ESOP or MBO), (2) cash for stock, (3) stock for stock, (4) stock for asset, etc., or the parties may even also decide to finance the deal through a combination of any of these financing tools.

What should primarily drive the parties' decisions about certain structure or financing options is how that structure and financing option will serve their interests on a case-by-case basis, but generally their main concerns in that regard could easily be identified as follows: (1) taxes (instant or deferrable tax), (2) availability of financial resources, (3) limiting the liability of the acquirer through a triangular structure, (4) how the target will operate after the merger, independently or wholly swallowed by the acquirer, (5) whether the target's agreements and licenses are assignable or not, (6) the complexity of the structure and how it may take time to be executed, and (7) the legality of the proposed 
structure in the jurisdictions where it will be registered and where the operations will be performed.

As an example of how the transaction might be structured, consider the following: The ESOP fund at corporation " $\mathrm{A}$ " and some of the shareholders of corporation "C" agree to jointly acquire "A," to keep " $\mathrm{X}$ " (operation unit in "A") operating independently, and to sell "Y" (operation unit in "C"), while the rest of "C" will operate as a part of "A." The structure may be as follows: The partners will incorporate a new corporation named "B," and then " $\mathrm{B}$ " enters into debt agreements with various lending sources. Following that, "B" will acquire controlling share of " $\mathrm{C}$," then " $\mathrm{B}$ " will acquire the rest of the shares of " $\mathrm{C}$ " in a squeeze-out transaction, then " $\mathrm{C}$ " will swallow " $\mathrm{B}$ " in a reverse triangular merger transaction. Next " $\mathrm{C}$ " divests " $\mathrm{Y}$ " through a carve-out transaction to a third party, followed by " $\mathrm{C}$ " entering into debt agreements with various lending sources to acquire " $\mathrm{A}$ " in an LBO transaction, resulting in " $\mathrm{A}$ " divesting " $\mathrm{X}$ " in a spin-off transaction, and at the end " $\mathrm{A}$ " swallowing " $\mathrm{C}$ " in a reverse triangular merger.

\section{(e) Closing the transaction}

Closing the transaction is the final step in the merger dynamics, and that crucial step will successfully finalize all the efforts made throughout the entire process of the merger transaction, and will put it into a working reality. Closing the transaction could be simply defined as "the event through which the parties to [the merger] transaction consummate that transaction by the execution and delivery of documentation, and, if applicable, the transfer of funds ...", and accordingly it encompasses two categories of closing issues, the first one being the corporate issues and the second the financial issues. ${ }^{561}$

The closing of the transaction, as a step in the row of steps in the merger dynamics, begins after all the preliminary negotiations, the due diligence, the valuation, the parties having decided on how the transaction will be structured, and the parties also having decided on how the transaction will be financed. The closing step starts by drafting and negotiating a definitive agreement to determine all the key terms and conditions of the transaction such as the representations and warranties, indemnification, payment terms and conditions, closing conditions, post-closing rights and obligations, how the transaction will be executed, and defining the remedies for any breach thereof. ${ }^{562}$

The tasks to be accomplished during the closing step are basically enormous and could be categorized into three phases: (1) pre-closing,

561 ReED, et al., The Art of M\&A, supra note 359, at 613.

562 Sherman, Mergers \& Acquisitions from A to Z, supra note 384, at 174. 
(2) closing, and (3) post-closing phases. ${ }^{563}$ In that context, drafting and negotiating the mentioned definitive agreement is a task in the pre-closing phase. Signing the definitive agreement is not recommended during that phase as it will be risky because there are still some closing conditions to be satisfied before signing the definitive agreement. ${ }^{564}$ It has also been reported that in most cases the parties sign the definitive agreement and close the transaction simultaneously during the closing phase. ${ }^{565}$

In addition to drafting and negotiating the definitive agreement during the pre-closing phase, the parties should do all preparations to satisfy any closing requirements and conditions as per the agreements, laws, and regulations in all the jurisdictions concerned, for instance, filing and obtaining all the required shareholder approvals; obtaining any required regulatory approvals such as antitrust clearance by the merger control authorities; obtaining approval by the stock exchange authorities where one or more of the parties is a publicly traded corporation, in addition to any industryspecific premerger approvals, and also any foreign investment or national security approvals. ${ }^{566}$

It should be noted that not only the volume of the transaction and how it will be structured will determine the time it might take to close, but the time will overwhelmingly depend on the tasks to be accomplished during the pre-closing phase. This is due to the fact that most of those tasks are in one way or another dependent on actions to be done by third parties or even the waiver of their rights, such as the antitrust authorities in a situation in which a premerger approval is required, and other third parties in cases where the assignment of the agreements with the target is a precondition.

To overcome any lengthy periods that the pre-closing phase might take, any negative effects it might cause to the operations of both the target and the acquirer, or on the prices on the stock exchange, and any changes to the governing rules and regulations in circumstances that a new law is adopted, the parties may sign the definitive agreement and arrange for an escrow account to be designated especially as a guarantee for the tasks that are not accomplished until the signing date. On the other hand signing the definitive agreement is sometimes a prerequisite condition by the regulatory authorities and the financing partners. ${ }^{567}$

563 REED, et al., The Art of M\&A, supra note 359, at 618.

564 Miller, Mergers and Acquisitions: A Step-by-Step Legal and Practical Guide, supra note 407, at 29.

565 REED, et al., The Art of M\&A, supra note 359, at 614.

566 Miller, Mergers and Acquisitions: A Step-by-Step Legal and Practical Guide, supra note 407, at 29, 77.

567 REED, et al., The Art of M\&A, supra note 359, at 614-615. 
The closing phase is usually short, ranging from a few hours to a few days, during which the parties must satisfy the final task checklist, which may generally include: (1) making a final review of the documents, (2) dating any undated documents, (3) signing all the documents that require such signature and have not yet been signed, (4) checking whether all the closing condition have been satisfied or waived, (5) making payments, and finally (6) delivering documents. ${ }^{568}$ Obviously, starting from the moment of signing the definitive agreement, the relation between the parties and any closing or post-closing issues will be governed by the definitive agreement not the initial preliminary agreement.

The last and final phase is the post-closing phase, during which each party will receive any remaining documentation that has not yet been delivered during the closing phase, as happens in some cases where the delivery of some documents during the closing phase is not possible. ${ }^{569} \mathrm{In}$ fact, during that post-closing phase, the parties have to implement what is known as the post-merger plan to overcome any challenges that the parties might face in the implementation, and they even sometimes have to mutually monitor the post-merger operations as in the case of earn-out transactions. ${ }^{570}$

It is noteworthy that the implementation of the post-merger plan might take a long time, starting from three months to more than six months, ${ }^{571}$ because in most instances it is an integration process between two or more different corporations in many aspects, such as operations, policies, financial and accounting perspectives, etc. In summary, that integration will mainly depend on the volume and the complexity of the structure of the transaction itself, and on many other factors like cultural differences between the parties to the merger transaction, where cultural differences are considered the main problem that might affect the smooth implementation of the post-merger plan.

While cultural differences do not lead directly to merger failure, they might have a negative impact on the implementation of the post-merger plan, or at least slow down the ideal integration level to fully realize the expected efficiencies from the merger. Consequently, it has been reported that most of the well-known mergers suffered from cultural differences, for example the mergers between Sony Corporation and Columbia Pictures, AT\&T and NCR, Daimler-Benz and Chrysler, Citicorp and

568 REED, et al., The Art of M\&A, supra note 359, at 622-623.

569 Id. at 629.

570 Sherman, Mergers \& Acquisitions from A to Z, supra note 384, at 21-22.

571 REED, et al., The Art of M\&A, supra note 359, at 649. 
Travelers Group, AOL and Time Warner, and Hewlett Packard and Compaq Computer. To demonstrate how crucial the issue of cultural differences is, consider the case of the Hewlett Packard and Compaq Computer merger transaction, where tremendous efforts were made, over more than two years, to identify the cultural differences to be overcome, and during which more than 144 focus groups were conducted in more than 22 countries. ${ }^{572}$

\section{CONCLUSION}

By the end of this chapter, many conclusions can be identified. The first is that the origins of the idea of the corporation and its development could be attributed to all humans throughout history; some ethnic groups thought about it, maybe others imagined its future, some just spread it or even developed it, but the most important fact was that it was mainly originated and developed for the good of them, i.e. humans. The second conclusion is that the early scholars did not contribute to its development as much as was expected; they just tried to describe what they experienced during certain periods, and they did not even give the full picture to their successors, although that could be attributed to the limited resources at that time.

The third conclusion is that the East India Company is an example of how that very same early corporation of the 17 th century is surprisingly still alive to date, and in fact it is not the only one, there are others. However, others like the South Sea Company were not just examples of early corporations, but they significantly changed the history of the corporation and its relation with the state, where they were used as government financing tools. In addition to that, it proved that the corporation could lead to the collapse of the whole economy whenever it was not used for the good of the people.

The fourth and actually a very important conclusion is that surprisingly the US antitrust laws were not enacted for the purpose of protecting the consumer, nor to bring trusts harmful to the American economy to an end; rather, these laws were actually enacted to support some jumpy farmers and some other small inefficient corporations, while also distracting public attention from the introduction of a new tariff Bill. On top of

572 REED, et al., The Art of M\&A, supra note 359, at 661-662, citing J. Robert Carleton \& Claude S. Lineberry, Achieving Post-Merger Success: A Stakeholder's Guide to Cultural Due Diligence, Assessment, and Integration, (Wiley. 2004) and it is noteworthy that Carleton's firm, Vector Group Inc. conducted the focus groups and interviews as consultants to HP. 
that, the trusts were beneficial for the economy or at least they were not engaged in anticompetitive behavior.

The fifth conclusion concerns the very surprising role of feudalism in the relation between the corporations and the state, and it literally opened the door for that relation to be developed in the future. Altogether that development could easily be portrayed as starting from the state granting monopoly and incorporation rights, and then the corporation offering for the state to make use of it as a financing tool to ensure approval for continuation, followed by the power of the state being lessened to help the corporation rescue the economy and to contribute to the industrial revolution. Next, when the corporation gained some power, as represented by the trusts, the state started a new era by reregulating the corporations again, but this time under a new scheme and in a more professional style. Again that did not succeed and led to two trends respectively: the privatization of corporations and then the deregulation of the markets.

The sixth conclusion is that the state's role in regulating the corporation originated and developed in the Western jurisdictions, while the regulatory role was not found in most of the Eastern jurisdictions, especially the Arab countries. That could be attributed to the fact that from the Islamic perspective, which prevailed in the Arab countries at least during the early developments of the corporate idea, the state should not intervene or introduce legislation to control the markets unless it was to rescue the market from total collapse, ${ }^{573}$ for instance there is nothing reported about any requirement or procedure to incorporate a new corporation in early periods.

Furthermore, the seventh conclusion is that mergers are not the only growth option for the corporation, from a legal perspective, and there are other alternatives, although the merger is always expected to be a more powerful tool that might lead to better results. However, that is not always the case and the parties may opt for other options. The eighth conclusion is that mergers are very highly complicated transactions, thus should be carried out only by specialized professionals, while most of the transactions are concluded and based mainly on highly subjective estimations and consume huge resources. The seventh and eighth conclusions actually raise very perplexing questions, which are mainly: Is it worth entering into such transactions? Does it really work in reality? Those questions and many others will be addressed in the next chapter. at 24 .

DabBaH, Competition Law and Policy in the Middle East, supra note 346, 